\title{
WestVirginiaUniversity
}

THE RESEARCH REPOSITORY @ WVU

Graduate Theses, Dissertations, and Problem Reports

2009

\section{An analysis of U.S. history textbooks: The treatment of primary sources}

Misty D. Rodeheaver

West Virginia University

Follow this and additional works at: https://researchrepository.wvu.edu/etd

\section{Recommended Citation}

Rodeheaver, Misty D., "An analysis of U.S. history textbooks: The treatment of primary sources" (2009). Graduate Theses, Dissertations, and Problem Reports. 4521.

https://researchrepository.wvu.edu/etd/4521

This Dissertation is protected by copyright and/or related rights. It has been brought to you by the The Research Repository @ WVU with permission from the rights-holder(s). You are free to use this Dissertation in any way that is permitted by the copyright and related rights legislation that applies to your use. For other uses you must obtain permission from the rights-holder(s) directly, unless additional rights are indicated by a Creative Commons license in the record and/ or on the work itself. This Dissertation has been accepted for inclusion in WVU Graduate Theses, Dissertations, and Problem Reports collection by an authorized administrator of The Research Repository @ WVU.

For more information, please contact researchrepository@mail.wvu.edu. 


\title{
AN ANALYSIS OF U.S. HISTORY TEXTBOOKS: \\ THE TREATMENT OF PRIMARY SOURCES
}

\author{
by \\ Misty D. Rodeheaver \\ Dissertation submitted to the College of Human Resources \& Education \\ at West Virginia University \\ in partial fulfillment of the requirements \\ for the degree of \\ Doctor of Education \\ in \\ Curriculum \& Instruction \\ Approved by \\ Dr. Mary Haas, Committee Chairperson \\ Dr. David Callejo-Perez \\ Dr. Samuel Stack \\ Dr. Robert Waterson \\ Dr. William Mahoney
}

Department of Curriculum \& Instruction

Morgantown, West Virginia

2009

Keywords: Social Studies; U.S. history; primary sources; textbook evaluation Copyright 2009 Misty Rodeheaver 


\title{
ABSTRACT \\ AN ANALYSIS OF U.S. HISTORY TEXTBOOKS: THE TREATMENT OF PRIMARY SOURCES
}

\author{
by Misty D. Rodeheaver
}

This dissertation examines the treatment of primary sources in three of the most widely adopted secondary U.S. History textbooks. Specifically examined were the types of primary sources, location of corresponding questions, classification of corresponding questions according by the Depth of Knowledge and the Library of Congress steps in examining primary sources, and presence of answers in the narrative. An instrument was created to assure transparency in assessing the textbooks. The results were examined through the interpretative frame works of historians and the various perspectives within the social studies. All texts incorporated many primary sources but varied greatly in their presentations of the documents. Recommendations for changes were made for each of the stakeholders with interests in publishing and using textbooks. 


\section{ACKNOWLEDGMENTS}

There are so many people that have carried me through this arduous process, and I am profoundly thankful to each and every person. Dr. Mary Haas, thank you for your guidance and infinite patience. As an advisor, you guided me through this task and were always there with the proper motivation to bolster my endurance. As a colleague, you introduced me to an invaluable number of fruitful professional opportunities, and as a friend, you provided comfort and reassurance. To the rest of my committee members - Dr. David Callejo, Dr. Sam Stack, Dr. Robert Waterson, and Dr. William Mahoney, I cannot thank you enough for all the countless hours of feedback and your willingness to serve on my committee. Additionally, each of you have pushed and challenged me both academically and professionally to strive for more, and I thank you for facilitating my educational pursuits. It has been an honor to work under each of you. Dr. Mahoney, I credit you with the spark that began my foray into graduate work. I never would have embarked on this journey had it not been for your influential presence.

To my family and friends, I owe you everything. Mom and Dad, there are no words to describe my overwhelming gratitude for all of the sacrifices you made all these years and for your unconditional love and support. Vennessa, where to begin? I am so thankful to know you have always been by my side and that you allow me to share in your joy with Caleb. For my extended family of friends - Libby, Christy, Chris, Harold, Rachel, Ken, Connie, Parker and the rest of my WVU family, a thousand thanks for the welcome distractions, the willingness to listen to my woes, and the fierce support you provide. I am a lucky woman to have people like you in my life.

Lastly, to my godson, your sweet presence and kind nature kept me going when I wanted to quit. Caleb, you are such a blessing. 


\section{TABLE OF CONTENTS}

Chapter 1: Statement of the Problem ................................................................... 1

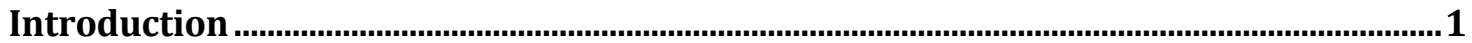

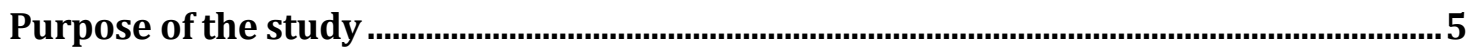

Limitations of the study .....................................................................................................8

Chapter 2: Review of Literature …........................................................................ 9

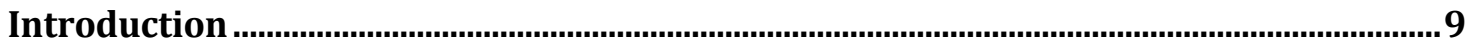

Historical emphasis of history curriculum........................................................................9

How history should be taught..................................................................................13

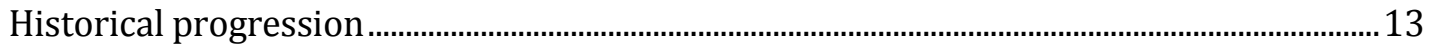

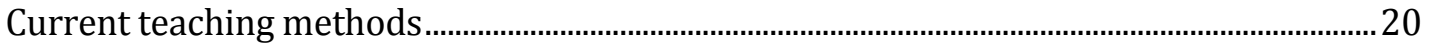

The role of the textbook in curriculum............................................................................23

Textbook evaluation ......................................................................................... 27

Types of textbook analyses...........................................................................................................................22

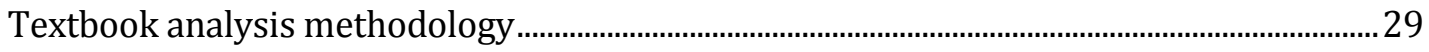

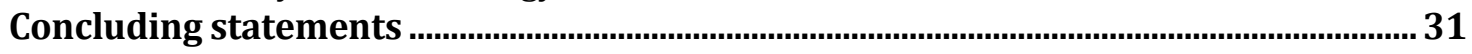

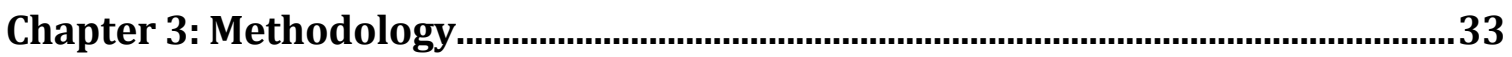

Introduction ................................................................................................. 33

Textbooks................................................................................................... 33

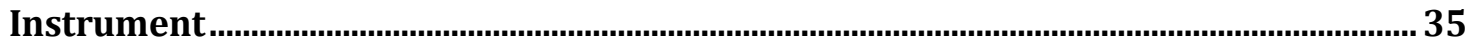

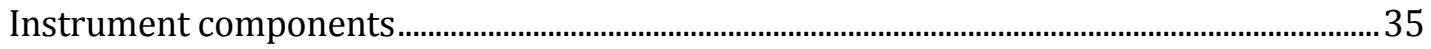

Instrument validity .............................................................................................................................37

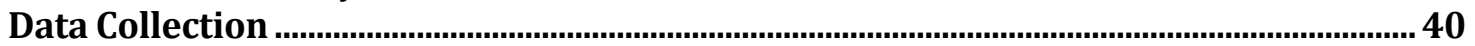

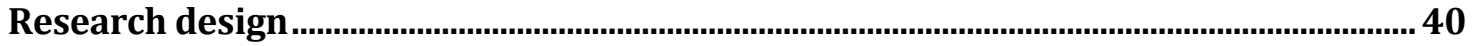

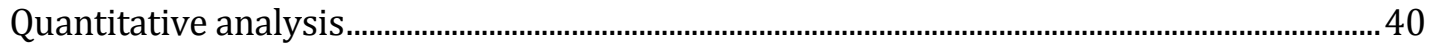

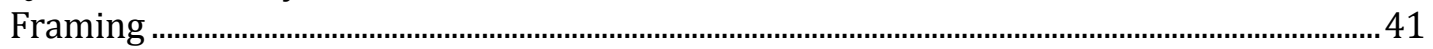

Implications............................................................................................................. 41

Concluding statements ............................................................................................ 42

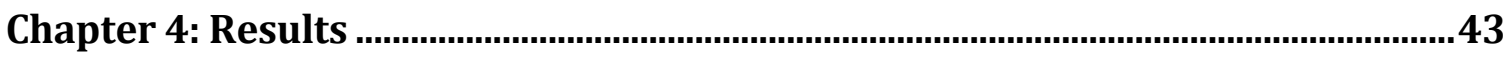

Introduction ........................................................................................................... 43

Description of selected textbooks.............................................................................................. 44

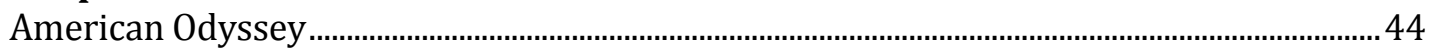

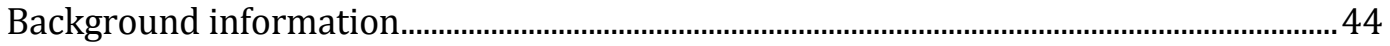

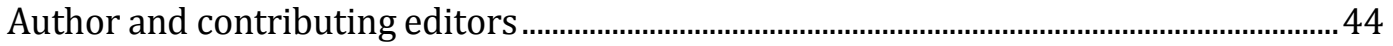

Additional stakeholders ..................................................................................................................45

Textbook description.........................................................................................................................4

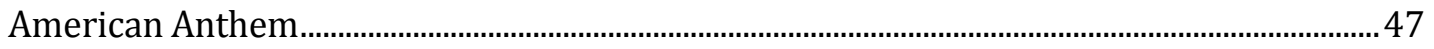

Background information................................................................................................................... 47

Author and contributing editors/consultants...............................................................................4

Additional stakeholders ....................................................................................................................4

Textbook description.....................................................................................................................4

A History of the United States .........................................................................................................................50

Background information ......................................................................................................50

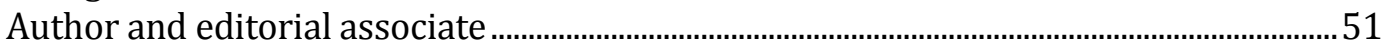




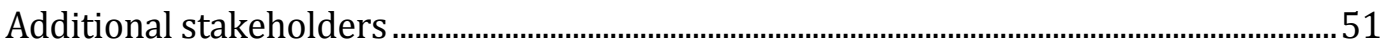

Textbook description......................................................................................................... 52

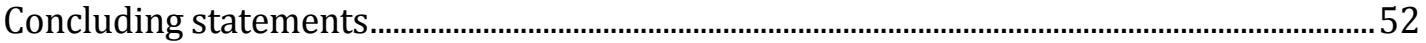

Description of primary sources

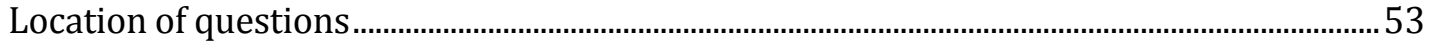

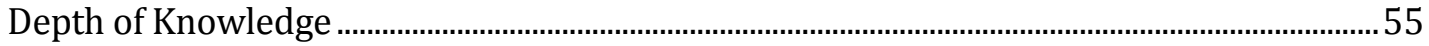

Library of Congress guidelines.................................................................................................... 57

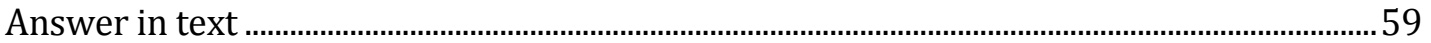

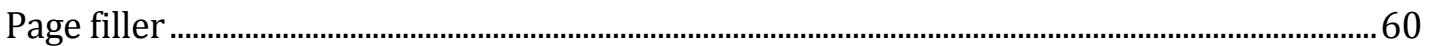

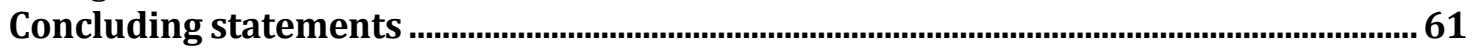

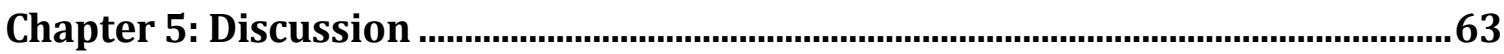

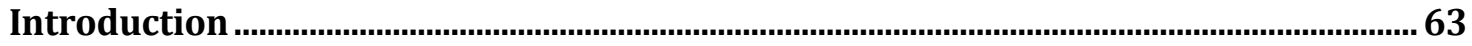

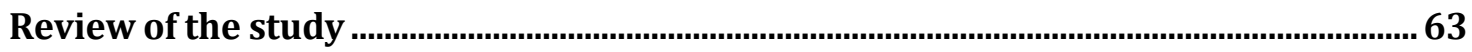

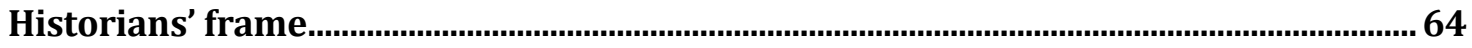

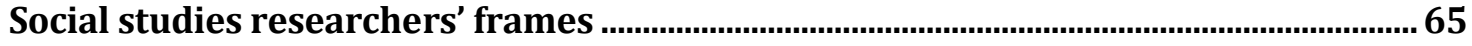

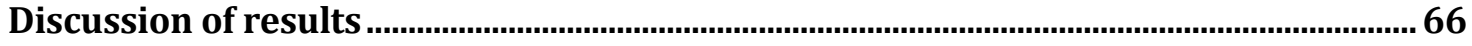

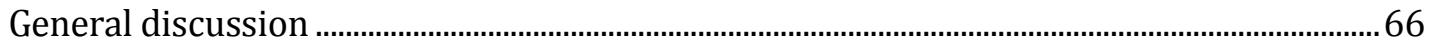

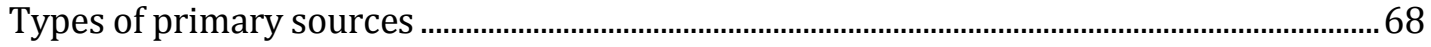

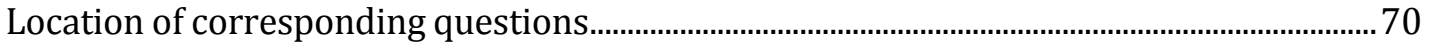

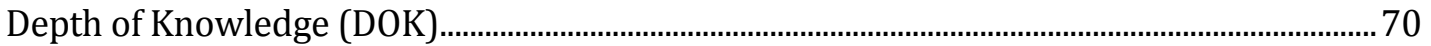

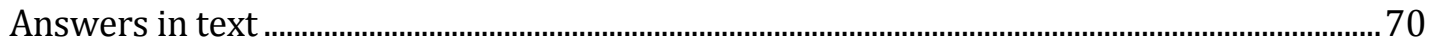

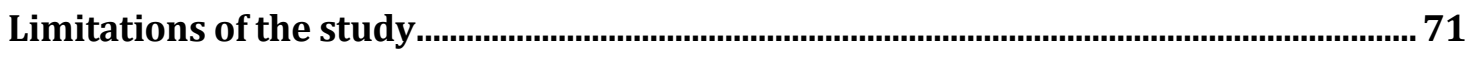

Future research

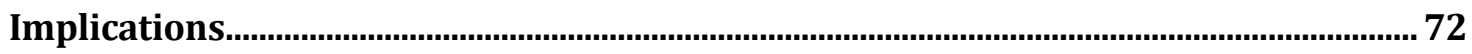

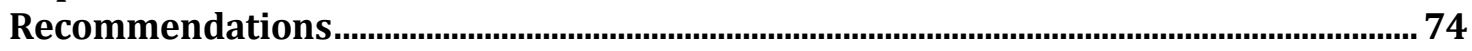

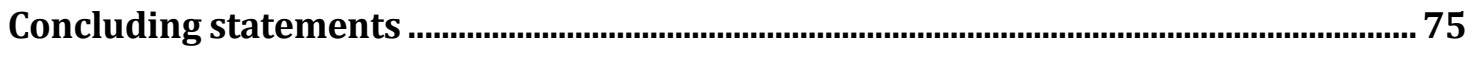

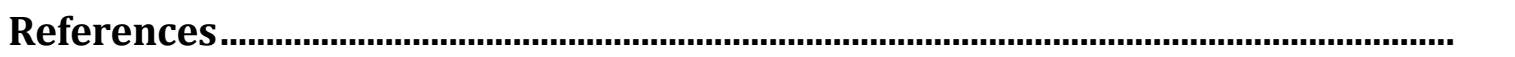

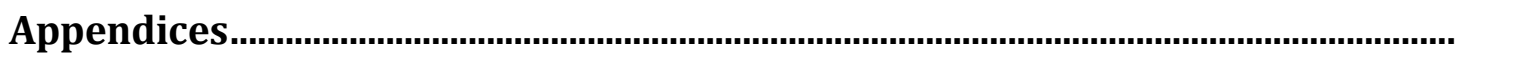

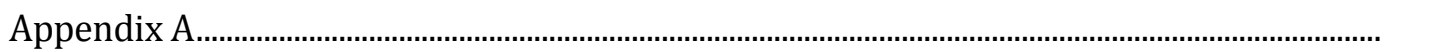

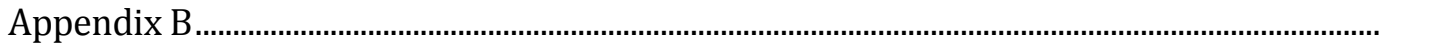




\section{LIST OF TABLES}

Table 1: Inter-rater reliability numbers and percentages for the classification of corresponding questions according to the guidelines set forth by the Library of Congress

Table 2: Inter-rater reliability numbers and percentages for the classification of corresponding questions according to the guidelines set forth by the Depth of

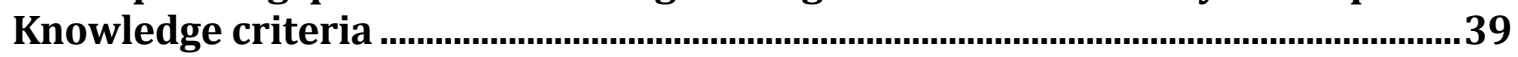

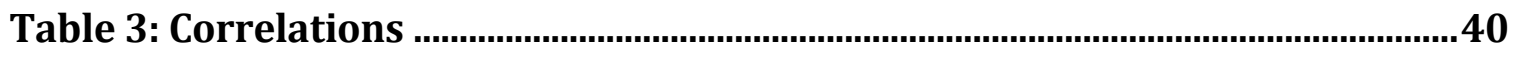

Table 4: Raw data and percentages for the locations of the corresponding questions.

Table 5: Raw data and percentages for the primary sources' corresponding questions' Depth of Knowledge (DOK) level ..............................................................56

Table 6: Raw data and percentages for the primary sources' corresponding questions' Library of Congress level of analysis ............................................................58

Table 7: Raw data and percentages for the primary sources' corresponding

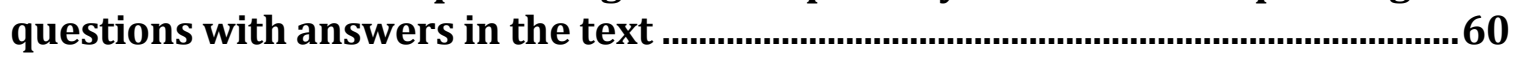

Table 8: Raw data and percentages of page filler primary sources ........................61 


\section{DEFINITION OF TERMS}

1. Depth of Knowledge (DOK) - A classification of the different problem solving skill sets that enables a person to answer a question, perform some other task, or generate some product that illustrates a student's understanding of a topic.

2. History - The written, oral, and graphic record of the past.

3. Library of Congress (LOC) Guideline for Primary Source Analysis - A four-step process for analyzing primary sources designed by the Library of Congress. The process involves scanning the source, examining the source, analyzing the source, and comparing the source with another.

4. Nation - The American nation represents a togetherness that gives expression to the shared aspirations of a people for equality and freedom - and to establish, nurture and maintain the institutions necessary for that purpose (Satyendra, 2003).

5. Primary Source - There are various kinds of primary sources, but for the purpose of this study, primary sources will be defined as a source originating from the time period examined. These sources include documents, excerpts from original documents, original photographs, artwork, interpretive artwork originating from the time period examined, images, transcripts of audio sources, and historical maps. Also included in this definition are contemporary photographs of historical/ancient sites created before the development of photography. Artwork released more than ten years following an observed period will be excluded, but artwork within that ten-year span will be treated as a memoir.

6. Stakeholder - The publishing house and its executives, the author, and any program consultants

7. The study of history - The interpretation of past events for the purpose of understanding subsequent events

8. Page filler - Primary sources that are presented in the textbooks but appear only on a cursory level.

* Such documents do not have corresponding questions that ask students to perform any tasks related to processing primary documents e.g.; scan, examine, analyze, and/or compare the sources. 


\section{Chapter One: Statement of the Problem}

\section{Introduction}

Historical writing is based on the interpretation of facts, and because of this, it sets itself apart from fiction or the imagination. In the absence of complete facts, logical inferences are used to interpret the available facts (Fischer, 1970). Historians seek these facts from and base their interpretations on various sources; the most important of these are primary sources. It is important to understand that even the most acclaimed historical writing is not, and never has been, based totally on fact and truth. All historical writing stems from the authors' personal biases and his or her interpretations of the facts, even those facts found in the primary sources. History textbooks, even in their sanitized state, still promote the agenda of the major stakeholders, especially when trying to formulate the idea of the American national identity or promoting their own agenda for social studies curriculum (Apple, 1986; Moreau, 2003). These seemingly obvious facts fail to permeate the American public school system as the educational system perpetuates the misconception of infallible truth in textbooks, especially when considering history textbooks (Holt, 1990).

Typically, students begin to learn history in schools by reading stories or narratives. Important to the educational experience is the examination of the different types of narratives read by the students. This examination provides the opportunity for students to recognize the differences between the various types of narratives utilized in the classroom. As an integral part of the learning of history, students must begin to evaluate narratives to determine if the narrative is indeed based on facts as well as recognize that the interpretation of these facts is done from the perspective of the observers, recorders, and authors.

For public school students, the most commonly and traditionally used historical instructional resource is the history textbook (Banks, 1969; NCSS, 1988; Ravitch \& Finn, 1987; Tyson \& Woodward, 1989). Wade (1993) in reviewing textbook use over a ten-year period concluded that $70 \%-90 \%$ of social studies instructional time during that decade was best described as textbook based. Additionally, the 1988 NAEP history survey results showed that only $39 \%$ of the $12^{\text {th }}$ grade students surveyed reported ever having read materials outside of the textbook (NAEP, 1990). Beyond its function as the main source of historical information, the history textbook also imparts great influence on the direction or the perspective of the history curriculum (Patrick \& Hawke, 1982). Disputes over which 
direction history curriculum should have remain hotly disputed (Camicia, 2008; Evans, 2004; Nash, Crabtree, \& Dunn, 1997; Symcox, 2002). Each major camp espouses a distinctly different perspective regarding textbook content and some of which have played a large role in the shaping of textbook content (Moreau, 2003).

In regards to the dominant presence of the textbook, one must also consider the fact that many schools operate with limited resources and funding therefore necessitating reliance upon the textbooks. Materials such as digital resources lack power in a classroom with one dated computer or in a classroom without a laptop and a projector. Despite the push for an increased technological presence, some school systems simply cannot meet the rising demands. Other considerations leading to the enduring presence of the textbook are the teachers' pedagogical approaches as well as their perceived level of comfort regarding technology (Etmer, 2005; VanFossen \& Waterson, 2008). Unfortunately, many researchers posit that history textbooks steer curriculum in a very dangerous direction, one often described as inhibitory. This direction impedes the students from the actual learning of history (Beck, McKeown \& Worthy, 1995; Woodward, 1987).

Typically, history textbooks tell a story and primarily focus on facts, events, and people as opposed to the kinds of evaluative and inferential questions and decisions that historians make when they examine sources. Even worse is the fact that the narratives and even the language used in textbooks closely resemble each other. Researchers recognize this and pen the occurrence as an epistemological "sameness" or "textbookese" (Brown, Collins \& Duguid, 1989; Paxton, 1999; Wineburg, 1991). Textbookese leaves history textbooks dispassionate in nature and oversimplifies the complex process with which historians interpret the past. Paxton also references studies in which American history students make few distinctions between historical writing and writing in other disciplines (Holt, 1990; Wineburg; Young \& Leinhardt, 1998). These researchers posit that one of the reasons for this lack of distinction is that history textbooks rarely model within their discourse practices the kinds of historical literacy practiced by historians. Textbooks do not promote the type of reading, writing, and interpreting utilized by historians.

Social studies researchers also beguile the American history curriculum for its inability to effectively promote democratic education with its approach toward controversial issues (Evans, 2004; Parker, 2003). The study of controversial issues is a central element in 
democratic education (Hess, 2008; Ochoa-Becker, 2007; Parker, 2003). Currently, researchers present multiple definitions of what constitutes a controversial issue and that has been compounded with the many rationales for why controversial issues should be included in curriculum. Despite having numerous examples of controversial issues and rationales for inclusion, the most common rationales state that controversial issue examination promotes public discussion of common problems (Mansbridge, 1990) and that considering controversial issues prepares students to competently participate in political engagement (Newmann \& Wehlage, 1995). Experiencing controversial issues in a classroom dominated by the textbook therefore requires the researcher to examine the textbook for the inclusion of controversial issues. Given the sanitized language and the "stick to the facts" dominant approach, it seems logical to assume that American history textbooks struggle to effectively address controversial issues.

One cannot wholly blame the textbook publishers for this curricular direction, as the "stick to the facts" approach is all but demanded as they follow state mandates. Cassanello (2006) expressed the concern and disbelief of historians over the history curriculum and the legislative attempts in key states like Florida pushing to limit instruction in history to "facts" rather than interpretation.

Complicating matters is the political decision of many key states such as California and Florida to abandon an integrated social studies curriculum in favor of other, restructured curriculum models (Levstik, 2008). In 1988, California moved to a history/social science framework, emphasizing history, focusing on the "then and now" comparisons and "people who make a difference" (California, 1988). In 1990, Florida also adopted a curriculum fusing history and geography into an integrated program, focusing on literature and the arts, as well as global comparisons (Florida, 1990). While this may sound similar to the inclusive program promoted by the National Council for the Social Studies (NCSS), the reality is that these programs veer further away from the integrated social studies approach. The school systems typically replace social studies programs with either integrated instruction or even just a humanities course, diluting social studies content (Levstik). Granted, these programs typically appear on the elementary level and not the secondary, but the results add difficulty for students when they reach the secondary level where they arrive without basic knowledge 
and experiences with history, political science, and geography, and are expected to excel in social studies skills and content (Passe, 2006).

Dovetailing with the restructuring trends is the fact that the already minimal instructional time allocated for social studies lessons has been in recent years further decreased or eliminated altogether (Levstik, 2008). This era of high-stakes testing greatly stifles social studies curriculum and limits the time teachers have to devote to the analytical aspects of the social studies courses (Ibid. Passe, 2006). This lack of time severely impedes the traditional history curriculum from changing and heading in what many social studies educators and historians consider a "more appropriate" direction. Gerwin and Visone (2006) observed teachers in New York City and found that the teachers of elective courses were more likely to focus on historical analysis and employ 'richer' use of primary sources than did those teaching state-tested secondary courses. The works of Grant (2004) and Crocco and Thornton (2002), also in New York City, suggested continuing a more complex trend. Crocco and Thornton found that more experienced teachers adapted mandated change to meet their own instructional styles more easily than did less experienced teachers, and Grant found that some teachers in state-tested classes felt more or less stymied by testing depending on their ideas about the purpose of history instruction.

Added pressures combined with an inability of all teachers to adapt accordingly, caused social studies courses, especially those state-tested courses, to suffer greatly. Starting with the elementary level, the impact of testing on social studies appears dismal. Von Zastrow and Janc (2004) and VanFossen (2000) each noted that in the aftermath of No Child Left Behind legislation (NCLB), emphasizing reading and mathematics, Indiana schools averaged less than eighteen minutes a day on social studies. A 3-year study (Rock et al., 2004) conducted in North Carolina also presented similar findings. Since many schools found little time for social studies lessons, a majority of these lessons were integrated into other curricular areas. This particular integrative practice greatly marginalized social studies content and skills even further and created a large handicap for public school students in their ability to develop skill sets and acquire content typically addressed in the social studies classroom.

The lack of presence and/or marginalization of social studies in the elementary level create a large handicap that secondary educators must address. Students enter secondary 
history classrooms not only lacking a sufficient content background, but also lacking the expected appropriate analytical and critical thinking skill sets. The 2002 and 2007 National Assessment of Educational Progress (NAEP) results presented a positive correlation relation between instructional time and students' test performance. Those students whose teachers spent over 180 minutes of instructional time per week on social studies scored higher on U.S. history assessments than those students of teachers spending less time a week on social studies (NAEP, 2002, 2007). The report went on to add that when additional instructional strategies such as using primary sources were included in the instructional time, these test scores improved at an even higher rate for not only fourth graders, but also for eighth and twelfth grade students. As Levstik (2008) notes though, the NAEP data includes only the frequencies as recalled by teachers and students. The data does not provide the instructional contexts for the activities, providing uncertainty as to what the students actually did with the primary sources, or the textbook for that matter. Additionally, Levstik clearly articulates that the data does in fact suggest that most instructional time remains tied to social studies textbooks as opposed to other tools or activities.

Reviewing the social studies curriculum and instruction as a whole, it is no wonder so many secondary history teachers tend to rely solely on the history textbook, despite its many deficiencies, as the primary resource for instruction. It should be noted though, that textbook authors and publishers continually work to improve their products for multiple reasons, one of which is to improve the learning of history and social studies. Textbook authors and publishers also work to accommodate a greater portion of learners who have a wide range of literacy needs. The textbook format is also undergoing a bit of a transformation from traditional print to a digital format. Regardless of this change, the content will most likely remain much like that found in the original textbook, and few schools have actually transitioned fully to digital textbooks therefore an examination of the traditional textbook remains important is it may reveal the content of the digital texts as well as offering suggestions on how they might be modified.

\section{Purpose of the study}

It is clear that the current status of social studies calls not only for increased analysis and debate regarding federal and state educational policies, but also for the evaluation of textbooks. The aim of this research was to evaluate recent U.S. history textbooks and to 
frame the findings within the perspectives of the differing curricular camps of the historian and the social studies advocate. Textbook evaluations waned in recent years. Published studies, tended to focus on three different areas: content analysis, comprehension, and social science discipline (Wade, 1993). Siler (1987) noted the subdivision of the content analysis studies category and said these evaluations fell in one of three categories: themes, groups, and historical events. Wade noted that textbook analysis extended beyond content and also examined textbooks on the basis of comprehension. This category primarily includes studies examining the literary aspects of textbooks that impede or enhance student learning and comprehension of main ideas and concepts, though other elements impede or enhance student learning. The last category Wade described was the social science discipline category. This category includes studies examining the textbook's general treatment of a particular social science or social science concepts from more than one discipline. This study fell under the umbrella of comprehension through examining the textbook's treatment of primary sources. This study attempted to determine the ways in which the most commonly used instructional resource utilized, or failed to utilize, the very potent historical resources of primary sources to aid the students' understanding of history while promoting the stakeholders' own definition of the nation.

Historians and educational researchers alike promote the use of primary sources in the history classroom (Banks, 1984; Barton, 2008; Cuban, 1993; Davies, Lynch, \& Davies, 2003; Levstik, 2008; Musbach, 2001; Paxton, 1999). Since historians utilize primary sources when trying to interpret past events, they believe such documents should be included in a history classroom. "No improvement in the methods of historical instruction in our high schools and colleges bids [will] produce better results than the plan of bringing the student into contact with the first-hand accounts of events, or, as they are technically termed, the primary sources" (Robinson, 1904). Primary sources, sources originating from the time period examined, provide the historian with direct and unmediated information about the object of study. From these sources, historians construct narratives of the past, but the ways in which these narratives are created and the techniques used to analyze primary sources have typically not been taught to students. There exists a body of research in which the students' ability to think historically has been examined (Greene, 1994; Leinhardt, 1994; Wineburg, 1991). These studies indicate that students tend to view history as a collection of 
facts. The facts are to be archived through reading and then cut and paste together in writing (Paxton). Young and Leinhardt (1998) also report that the assignments provided to public school students often resemble retelling reports of facts presented in the classroom discussion/lecture or from the textbook. This lack of training creates situations in which students misinterpret or fail to understand the truth of events. This is very misleading and brings about actions and decisions that have serious consequences. One such consequence is a failure of students to adequately learn abstract concepts. This consequence is a direct result of the failure to engage the students in the classroom, a situation created by a lack of proper training (Barr, Barth, \& Shermis, 1977). That is not to say that other factors are not influencing a student's ability to master abstract concepts and critically evaluate information. Students are prone to quickly reading passages, guessing at the point of the passage, or simply adopting the conclusions of authors without engaging in any kind of evaluative exercise. This, however, does not lessen the importance of proper training for both students and teachers (Ibid).

Public school teachers are expected to concern themselves with students' abilities to not only master the material but to also develop critical thinking skill sets, all of which can be assisted through the proper use of primary sources. When conducting a simple search on the Internet for primary sources, thousands of sites appear. The difficult task is to determine which sites provide authentic sources or which sites are worth using. The solution is to follow the path of the historian. Historians examine bibliographies of acclaimed secondary sources, conduct searches through search engines, and utilize periodicals and newspapers from the examined time in order to identify primary sources (Dietering, 2008). One of the most common stops in the search of this historian is the Library of Congress. The largest library in the world, the Library of Congress is the research arm of Congress and is the oldest federal cultural institution (Library of Congress, www.loc.gov/about). The Library of Congress is home to over 130 million items, including the largest collection of rare books in North America, and the world's largest collection of legal materials, films, maps, sheet music, and sound recordings. In addition to the numerous physical structures, the Library of Congress also operates a website in which many documents are readily available for public use and access. In the website, the Library of Congress also devotes a lengthy section for 
teachers. This section provides teachers with the necessary tools to utilize primary documents in the classroom, including how to effectively examine primary sources.

From the perspective of the historian, the ways in which textbooks include primary sources should also promote the historian's models of inquiry and analysis and not simply appear as a page's filler. Social studies advocates would also promote the purposeful use of primary sources as it develops the critical analysis skill sets and can set the proper stage for the promotion of democratic education. Since the primary form of social studies instruction lies with the use of textbook, it is necessary to assess how textbooks treat primary sources. The search for textbook evaluation studies from the past ten years revealed a dwindling number of studies compared to the studies published from the previous ten years, and none adequately addressed the treatment of primary sources by textbooks. In general, this study addressed the examination of U.S. history textbooks, and more specifically, it addressed the ways in which U.S. history textbooks treat primary sources. Therefore, this research provides data that describes the quality of U.S. history textbooks' promotion of historical thinking in ways that historians or social studies researchers support. Additionally, the research examined the ways in which textbooks utilized primary sources to promote the various stakeholders' agendas.

\section{Limitations of the Study}

This study focused only on the student version of the textbook and excluded the teacher edition of the textbook as well as any supplemental materials. The suggestions provided are based solely on an analysis of the student textbook. The exclusion of Advanced Placement textbooks from consideration also limited the study. The textbook selection was limited to only one type of textbook for the purposes of evaluation, thereby excluding a portion of history textbooks. Additionally, Advanced Placement textbooks were excluded from this study in an attempt to examine general studies textbooks independently and hopefully eliminate additional confounding variables. The final limitation was the size of the sample. Three textbooks, while representative and released by different publishing companies, were not the whole of the most widely adopted textbooks. 


\section{Chapter 2: Literature Review}

\section{Introduction}

The previous chapter outlined the necessity for a study that evaluates secondary history textbooks regarding the manner in which they utilize primary sources. This chapter will briefly visit some of the existing literature regarding four major topics:

1. The historical emphasis of history over other social studies courses and the integrated social studies course in the secondary classroom

2. The ways in which researchers suggest history should be taught

3. A review of the role of textbooks in curriculum

4. A review of the textbook evaluation literature

\section{Historical emphasis of history curriculum}

Overall, the discipline of social studies experienced major transformations that were indicative of the changing political, social, and economic influences throughout the nineteenth, twentieth, and now the twenty-first century. These changes still dictate, the ways in which educators present content as well as the type of content. Debates raged over the methodology but historically speaking, American educators inconsistently adopted social studies education (Mahony, 1988). Depending on the climate of the time and region, one may notice separate history courses and at other times a history curriculum imbedded within an overall social studies theme. There were times though that other disciplines included in the social studies took a greater precedence, such as geography, which maintained a dominant academic presence for nearly a century.

Prior to US independence, textbooks naturally presented materials from a Britishcentric perspective, but this changed with the development of American geography textbooks in 1784. Morse's textbooks, while taking an Ameri-centric approach, maintained the status quo of rote memorization and focused primarily on the geographical features of the newly created nation (Mahony, 1988). Politically, the United States concerned itself with the solidification of a strong nation. Nationalism, democracy, and expansion on the federal level trickled down through the educational system and permeated the curriculum (Henretta, et al., 2006). Socially, the notion of a unified people, embracing commonalities and releasing the chains of the Motherland or Fatherland also pushed curriculum toward the 
Ameri-centric approach.

In the 19th century, American secondary schools incorporated some of the European educational techniques, thus replacing rote learning with more inquiry learning, as well as the inclusion of additional subjects. The blossoming educational relationships between the United States and Germany and other European nations helped facilitate this change. "German ideas did not influence the American colleges at first, but rather the common schools and the education of the masses" (Walz, 1936). Prussian schools experienced a period of modernization in the early nineteenth century. This reorganization allowed for the rich along with the poor equal opportunity for schooling. The government took on a paternal disposition with its people and this notion slowly caught on in the United States. Many American educational journals contained translations of German articles describing methods of instruction and training of teachers as well as any other articles simply pertaining to German schools. These articles flooded the education profession and many educators found validity in their points. Walz describes five major principles that America gained from the German education system.

1. Education is a state and parental duty

2. There should be general taxation for schools $\mid$

3. Success is largely due to trained teachers, from education departments in universities

4. The United States should imitate the superior machinery of [the administrative aspects of] Prussian schools

5. More science, civil government, good citizenship, drawing, agriculture classes should be introduced.

All of these additions vastly transformed the educational experience in the United States, and perpetuated some of the persistent curricular themes we still see today such as civil government and good citizenship. Both of these curricular themes maintain a strong presence in courses such as history, thereby helping to facilitate history's growing presence within the educational system, so much so that it displaced the dominant social science course, geography.

Researchers tend to disagree about the dominance of certain disciplines in the social studies curriculum before the 1890's (Jenness, 1990). The dispute mainly exists between 
researchers who posit the dominance of history over geography or vice versa (Peet, 1984; Tryon, 1935). Despite this disagreement, one cannot argue the rising importance of the two disciplines and the push of their respective organizations to increase their disciplines presence within the American educational system. Changes emerged toward the end of the last decade of the 1800's. These changes pushed history into the status of the most dominant discipline within the social studies. The National Educational Association's (NEA) 1893 report further increased the importance and presence of the history discipline as the report recommended an eight-year uninterrupted sequence of history beginning in the fifth grade with general history carrying through the twelfth grade with Civil Government.

The American Historical Society (AHS) increased its influence on the American educational system in 1899 when it released the first of a series of reports on The Study of History In Schools. The report reemphasized the charge put forth by the NEA regarding the solid sequence of history courses on the secondary education level. The AHS chose to focus most of the attention to the upper grades (9-12) and their sequence included Ancient History, European History, English History, and American history/Civil Government.

Their report sparked a series of additional reports issued by other organizations such as the American Political Science Association and the American Sociological Society. The intent of these organizations, which were struggling with their own identities, was to combat the historical associations dominance in the educational system and push for a greater inclusion of their own disciplines (Engle, 1971). Their aims feel short as history courses maintained their dominance within the secondary educational system. Even the official introduction of the integrated social studies could not loosen the stronghold of the historybased curriculum.

The term 'social studies' was first officially used when the Committee of Social Studies was appointed in 1913 (Hertzberg, 1981). The Committee was a part of the Commission of the Reorganization of Secondary Education and was appointed by the National Education Association (Ibid). One of the prominent members of the Committee of 21 was noted historian James Harvey Robinson. Among other things, the committee outlined the purpose of the social studies. It was the belief of the committee that the purpose of social studies was to cultivate good citizenship (Bureau of Education, 1916). The Committee defined a good citizen as one who: 
"appreciates the nature and laws of social life, one who has an intelligent and genuine loyalty to high national ideals, one who has a sense of the responsibility of the individual as a member of social groups, one who has a sense of the responsibility of the individual as a member of social groups, one who is characterized by a loyalty and a sense of obligation of his city, state, and nation, and to the human race, and one who has the intelligence and the will to participate effectively in the promotion of the social well-being (Ibid)."

The Committee also proposed a general course outline for secondary schools. The courses proposed were geography, European history, American history, and civics for the middle school levels and world history, American history, and problems of democracy for the high school levels (Ibid). Ideally, the Committee wished to subscribe to a more Deweyan approach toward education, but many school systems chose to implement the suggestions of the report with a pedagogy that promoted that the road to good citizenship is paved with knowledge, especially knowledge gained in the history classroom (Engle, 1971).

For many, the terms social studies and history are synonymous, despite the clear delineation set forth by major organizations such as The National Council for the Social Studies (NCSS). NCSS defines the social studies as:

the integrated study of the social sciences and humanities to promote civic competence. Within the school program, social studies provides coordinated, systematic study drawing upon such disciplines as anthropology, archaeology, economics, geography, history, law, philosophy, political science, psychology, religion, and sociology, as well as appropriate content from the humanities, mathematics, and natural sciences. The primary purpose of social studies is to help young people make informed and reasoned decisions for the public good as citizens of a culturally diverse, democratic society in an interdependent world. (NCSS, 2008). While social studies is defined as an integrated study of the social sciences and the humanities, NCSS defines the history course as a discipline-based course, something distinctly different than a social studies course (Ibid). The lack of distinction by many indicates the overwhelmingly dominant influence of history over the integrated study of social sciences and the humanities as well as the other discipline-based courses. Thanks to the constant influence of historical organizations and the longstanding precedence for the 
inclusion of history courses, though its power has diminished somewhat, history remains the most commonly taught course of the social science and humanities discipline-based courses. How History Should Be Taught

The previous section discussed how history dominated the secondary social studies courses for over a century. History dominated so much so, that the secondary courses were rarely entitled social studies or even social science (Robinson \& Kirman, 1986). The basic pattern of secondary curriculum set forth in 1916 by the NEA endured the numerous reform movements and history courses remained relatively stable. That is not to say though that social settings bore no affect on the curriculum, as all social studies courses, no matter the decade, tend to reflect the social setting in which they exist (Wronski \& Bragaw, 1986).

This section of the literature review will address the impact of the political, social, and educational movements on the ways educators teach history. This section will also discuss the current literature regarding the methods educators should implement as they teach history.

\section{Historical progression}

The 1893 report from the NEA's Committee of Ten stated that in addition to the previously discussed sequence of eight consecutive years of history, there should be no distinction between the subject matters offered to college bound students and those who would enter the work force after high school. The Committee also stressed that history classes address issues such as civil government and economics (Ibid). The Committee did not, however, outline the ways in which these courses were to be taught.

While the Committee of Ten refrained from placing such suggestions, the American Historical Association's 1898 report recommended appropriate practices regarding the teaching of history. They suggested that the four years of history previously outlined in this literature review be designed around good textbooks and taught by trained instructors. Their report also suggested that the courses encourage students to company a wide variety of sources (Ibid). The 1909 report from the AHA extended their suggestions to include the elementary years. The report suggested teachers prepare their students to better understand their society and explore ways in which to constructively participate in said society (American Historical Association, 1910). It was also the suggestion of the AHA Committee to refrain from introducing separate courses in other social science and humanities 
disciplines. Rather, those disciplines could be introduced at appropriate times in the history course (Ibid). The report also suggested teachers relay history in a narrative format, more akin to a story. While surfacing nearly a century ago, the reports from the AHA strongly influence the ways in which American educators teach history courses, even to this day.

The report from The Committee on the Social Studies released in 1916 created somewhat of a rift between some educators and historians regarding the aim of history. Prior to the issuance of this report, educators and historians alike promoted the aim that history instruction develops students' intellectual abilities (Watras, 2002). The 1916 report struck a chord with educators more so than historians as it promoted the aim that history courses help students develop a strong sense of patriotism and the appreciation of those who advance civilization (Ibid). The report also suggested that history be taught in such as way as to relate the materials to the life of the students (National Education Association, 1916). Their suggestions also implied a lesser reliance on textbooks than the reports issued by the AHA. This report signaled the entrance of differing approaches toward teaching history, but that does not imply that the AHA's suggestions fell to the wayside. Rather, other instructional methods began to surface around the country alongside the traditional methodology.

The research and writings of Harold Rugg in the 1920s and then George S. Counts in the 1930s urged teachers to revaluate their methodology within the history classes and to modify their methodology. Rugg felt that while the aim of preparation for life's activities was noble, the practices used in the classroom did not foster such preparation. He correctly observed that students were simply memorizing information, none of which illuminated the current social conditions (Rugg, 1923). He urged textbook writers to reorganize their information to present the content as a series of social problems. Rugg also urged the fusion of social science disciplines so students could examine the social problems with a greater level of depth and understanding (Ibid). Rugg went so far as to publish his own series of textbooks modeled after this fashion and gained wide popularity until his critics issued allegations of Rugg being a traitor. The textbooks aimed to make history and social sciences meaningful and interesting. The textbooks framed themselves with current issues and problems as opposed to the traditional historical narrative (Evans, 2007). Additionally, Rugg attempted to create textbooks that weaved various social science disciplines into a curriculum developed to address social worth (Rugg, 1921). His textbooks presented 
multiple perspectives so social issues and encouraged students to refrain from taking a passive position regarding social justice (Kliebard, 1995).

Right-wing critics of Rugg believed his books unfairly criticized the United States and painted a very negative image of the nation, thereby destroying the underpinning of the student's patriotic development. Rugg faced a much more conservative political climate, shades of which still exist today. In place of Rugg's suggestions was the 1936 report from the Commission on the Social Studies. The suggestions of the report worked around the critics arguments of textbooks portraying American life in a negative way and suggested that the curriculum and textbooks organize themselves in such a way that students could apply their own experiences to the materials while still recognizing that the fundamental human activities may differ from society to society and that essentially societies simply adjust themselves to the external world in different ways (Marshall \& Goetz, 1936).

Much like Rugg, Counts called for societal change. While he believed in the promise of the Progressive Education movement with its intent to promote social welfare, he was also quick to challenge Progressives to seek out a truly progressive course of action, to become more than just talk (Counts, 1932). He believed that progressive education must: "face squarely and courageously every social issue, come to grips with life in all of its stark reality, establish an organic relation with the community, develop a realistic and comprehensive theory of welfare, fashion a compelling and challenging vision of human destiny, and become less frightened than it is today at the bogies of imposition and indoctrination. In a word, Progressive Education cannot place its trust in a child-centered school" (Ibid).

Counts' criticisms of the Progressives helped spurn the development of a different educational philosophy, social reconstructionism, which called for the development and implementation of an educational curriculum whose aim was social reform. Counts's justified claims accurately articulated a growing concern within our society. Urbanization, immigration, and industrialization forced considerable economic and social change (Katz, 1968). These changes started much earlier in our history, creating what Katz refers to as a 'new society,' but with the massive population growth, these concerns of the new society became quite severe and many, like Counts, believed schools should address the social deficits created as a result of this change. 
Politically and economically, the decades following World War II found the United States introducing itself as the new hegemony. This sudden rise to power altered the very fabric of the American nation. European nations looked toward the United States for economic relief and the Marshall Plan provided the answer. The United States also played a critical role in the political aftermath of the war redrawing political boundaries and doling out consequences on the losing parties. Other Allied nations endured drastic consequences as most of the fighting occurred on their soil, but the United States escaped such a situation. This fortunate string of events placed the United States in the plumb position of hegemony, a position the country still desires to maintain.

These decades also introduced the county to several prolonged decades full of fear of war or the fear of potential wars. The drastically different political ideologies of the United States and the Soviet Union sparked a Cold War that soon divided the globe into two major spheres of influence. Several hot wars flared as a result of the Cold War and many more diverted. In addition to the polemic division of the globe, this era also experienced fierce competition between the two powers. The launch of Sputnik by the Soviets in 1957 created frenzy in the American educational system (Gross, 1983). The American government told its people the United States would be the nation that would win the space war; and the Soviets clearly deflated that balloon. Congress conducted hearings in hopes of uncovering the reasons why the Soviets accomplished this feat before the United States. Congress called upon the father of the atomic submarine, Admiral Hyman Rickover, and he blamed the American educational system, specifically that progressive education programs, for our inadequacies (Ibid, 37). The lack of importance placed on scientific disciplines caused our problems. He testified that the Soviet Union educated its students with scientists, mathematicians, and engineers while our nation focused on life skills and other programs. This testimony and the rampant McCarthyism stifled academic freedom even on the elementary and secondary levels.

Congress concluded its hearings and quickly implemented new legislation calling for revitalization and greater emphasis on science and math courses. Naturally, the social studies programs required a restructuring of its own in order to better fit in this new educational system. The era of intense competition and constant fear created the perfect atmosphere for an increased demand for the educational system to focus most of its social 
studies attention toward lessons devoted to teaching students the necessary knowledge, skills, and attitudes necessary for effective participation in a democratic society (Barr, et al., 35). Citizenship education took center stage, though different schools of thought approached citizenship education in very different fashions. Schools separated social studies courses and focused a majority of the time and resources on history and American government courses. This naturally meant that the geography curriculum take a backseat, or at least take a diminished role. Most schools relied on pedagogy centered on rote memorization and uncritical transmission of cultural values (Ibid). The resilience of this pedagogy endured and still lingers despite the efforts of many educational reformers.

By 1960, the turmoil of the 1950s set the scene for revolution, not just political or social, but also academic. President Johnson's Great Society called for social and economic reforms in various areas of domestic policy. The political reforms sought to place into law several pieces of legislation designed to preserve and strengthen the cause of the Civil Rights movement as well as battle poverty through the creation of programs such as Food Stamps, Head Start, and other similar programs (Henretta, et al., 2006). Johnson did not stop his domestic reform program with these two major areas, but he also extended his reform into the educational system. The Elementary and Secondary Act of 1965 passed shortly after its introduction and earmarked a billion federal dollars for the improvement of the public schools. The Act designated this money for the establishment of special education programs and permanent Head Start programs in concentrated areas of low-income families. In 1968, President Johnson enacted one of his last major educational initiatives with the Bilingual Education Act, which provided support to schools educating limited-English speaking students (Andrew, 1998; Bernstein, 1996).

The history courses of the 1960s reflected the need for change and new and innovative materials from scholars of all social science disciplines began filling journals and bookshelves. Federal grants, abundant in nature, attracted many of these individuals, and helped to perpetuate the New Social Studies movement (Barr, et al.,1970). The New Social Studies movement attempted to change teaching styles and curriculum content in those K12 courses labeled social studies. The reformers' watchwords were concepts, generalizations, the structure of the disciplines, inquiry operations, social issues, values clarification, and attitudes and value development. Some of these ideas have been rejected; 
others have found a place in the conventions of social studies instruction and curriculum (Fenton, 1991).

Ultimately, the New Social Studies movement failed due to two main reasons. This movement, along with other educational movements in differing disciplines evolved, as a direct reaction to the intense competition with the Soviet Union that started in the 1950s (Herbert \& Murphy, 1968; Hunt, 1962). This competition led to the focus of developing inquiry skills and restructuring disciplines in order to maximize educational efficiency. This rigid structure failed as the social and political climate changed. The decade of the 1960s, with the Civil Rights Movement and other social movements required the attention of teachers and these subjects could not be rigidly placed into one particular subject. These multidisciplinary topics required multidisciplinary courses, thus rendering useless the curriculum packages created in the New Social Studies movement. The movement also failed due to its lack of recognition of the need to discuss the world in which students currently lived and the world in which they will live. The new social movements required discussion regarding these two main areas in addition to the mastery of inquiry skills, but the movement incorrectly prepared for this situation (Fenton, 1991).

The next two decades witnessed a return to the basics. This movement, interested in conservative political beliefs and blind patriotism, also called for the return to basic facts, knowledge, and understanding (Barr et al., 49). This movement naturally led history curriculum back on the path of civic education. Naturally, the teaching innovations of the New Social Studies movement were slow to fade and even well into the 1970s still found supporters (Banks \& Clegg, 1973; Ehman et al., 1974). The support of the New Social Studies movement started faltering though with each passing year. Stronger than the research and findings of these groundbreaking researchers and innovators was the pull of the Basic Education movement. George Weber, former Associate Director of the Council for Basic Education, believed this movement was a direct reaction to key events and phenomenon such as Watergate, Vietnam, the decreasing societal approval of disciplining children, the rise of National Assessments, and the excess of superficial innovations (Barr, Barth, \& Shermis). Vietnam certainly sparked a huge influx in the college enrollment as well as grade inflation for those young males who would surely face a draft if removed from higher education. Herbert Kohl's 1969 book The Open Classroom, a book chronicling the 
needs for open education, embracing the poor and students of color, also generated a huge backlash that contributed to the development of the Basics movement. Open education focused on active, student-centered classrooms with a holistic learning approach (Huitt, 2001). Conservatives found this method deplorable. School boards limited academic freedom, which in turn further limited change and reform and pushed history curriculum into the old pedagogies. Cynicism replaced the optimism of the earlier decade and textbook controversy emerged at rapid rates.

The Heritage Foundation and the New Right gained considerable power during the 1980s while the liberal camps slowly disintegrated. The combination of these two powers greatly influenced schools to promote such causes as promoting creationism, censoring textbooks, fighting secular humanism, and promoting free enterprise (Evans, 2004). At the time, the public image of the school system hit an all-time low. Newsweek already ran an article in 1975 that fueled the literacy crisis and Gallup Polls indicated low public school approval ratings, ratings that declined with each poll. These fears prompted researchers to wildly cling to the basics movement with no regard to its potential outcomes (Achilles, 1977). As a result, it seems as if the public lost confidence in the school system at the same time the national government unleashed its publication A Nation At Risk.

A Nation At Risk came out of the conservative Reagan era, an era in which conservatism reigned in all realms including economics, foreign policy, and even education. President Regan supported a conservative educational agenda sought to greatly reduce the federal government's monies and other resources and promoted things like school choice and pushed for prayer in schools (Cannon, 1991). A Nation At Risk sparked widespread fear and concern with its dooming statistics illustrating our students' literary, scientific, and mathematical failures. One of the recommendations of the report was the creation of content changes. The report suggested schools require that students take four years of English, three years of mathematics, science, and social studies, and one half year of computer science (US Department of Education, 1983).

The decade of the 1990s ushered in the wave of multicultural and global education. The explosive development of the Internet and the widespread use of technological tools such as podcasts, videos, interactive programs, and online classes only further stress the need for global and multicultural education. As the terrorist events of September 11, 2001 
provide very salient example of the need to understand others and the world in which we live. The new movements for multicultural and global education pushed for curricular adjustments especially in the World and American History courses (Burack, 2003). Even the Advanced Placement tests reflected this change as the Advanced Placement World History course was added in 2001 (Ibid).

Adding a multicultural and global perspective requires a certain change in curricular direction. Diane Ravitch (1990) once wrote, "Paradoxical though it may seem, the United States has a common culture that is multicultural." There are some elements and ideals that make peoples similar but we must also address those that make us different from each other. This notion flies directly in the face of traditional approaches that tried to streamline students into an idea of sameness.

Researchers endlessly debate the ways in which curriculum should reflect multiculturalism (Ahmad, Brodsky, Crofts, \& Ellis, 2001; Anderson, 2001; Ellington \& Eaton, 2003; Burack, 2003; Dunn, 1999; Ravitch, 1990 \& 2003; Schlesinger, 1998; Sleeter, 1995). The problem is how does one create a curriculum that fairly describes the experiences and contributions of all groups? The ways in which individuals determine what is fair varies widely from person to person and therefore this debate continues to rage. Ellington and Eaton (2003) wrote several suggestions curriculum developers and teachers should take into consideration when looking to include multiculturalism into the social studies curriculum. Their first suggestion asks teachers to develop courses that fairly describe the experiences and contributions of minority groups. Again, what is fair? Whose contributions should teachers include and whose should be excluded during their very finite instructional time? They did manage to present a very solid suggestion when they suggested teachers not take on the role of social activist but rather allow the students to examine the materials and develop their own interpretations and analyses of history after first being grounded in evidence-based studies that examine multiple perspectives.

\section{Current teaching methods}

Regardless of the outcomes of these societal shifts, the debates between historycentered approaches toward social studies and the integrated social studies have not been resolved (Nash, Crabtree, \& Dunn 1997). Proponents of both sides remain at a stalemate leaving educators dangerously close to a state of stagnation. Because it is not the nature of 
this study to validate one camp's argument over the other, it will simply address the methods encouraged for teaching under the current state of affairs, which presently still favors a history-centered approach.

Teachers should promote the students ability to explore the relationship between an event and the subsequent events. E.H. Carr (1961) calls this a dialogue through time. Essentially, when one engages in this discussion, one interprets the past event. History is interpretative by nature, and its study should reflect this notion. How exactly should educators go about presenting the information then?

First, educators must realize that the study of history requires a multidisciplinary approach (Whelan, 2006). One cannot simply understand the Great Depression by examining official government documents from that era. A richer understanding of the Depression can be gained by exploring economic reports; elements from popular society such as songs, books, personal journals, and movies; migratory patterns; weather reports from the era; and so on.

Second, students should not simply consume the conclusions of others and fail to produce any meaning for themselves (Ibid). Typically, history curriculum does not foster this approach and chooses to push information at the students with little to no meaning making. Again, the true study of history interprets past events as a means of understanding subsequent events. This interpretation is rife with one's own personal experiences and point of view, even the most skilled historian. One should not expect interpretations to be free of such biases rather; we should explore these biases as part of our own understanding of the past events.

The actual activities in the classroom used to achieve these goals should possess the following characteristics:

- Active

- Creative

- Exercise the student's power of critical judgment (Levstik \& Barton, 2001)

Some of the most critical tools available for educators to use in hopes of effectively teaching history are primary sources. Primary sources are the backbone of a historian's research. All secondary reports of any worth extensively examine and interpret primary sources alongside the previous secondary reports of an event. Most students do not 
recognize that historical accounts are developed from personal interpretations of primary sources and even when they learn about the ways in which these accounts are developed, they fail to take a critical approach toward these sources (Barton, 2008).

Historians, organizations, and educators alike laud the importance of primary sources within the secondary classroom (Andreetti, 1993; Ashby, 2004; Banks, 1984; Barton, 2008; Cuban, 1993; Davies, Lynch, \& Davies, 2003; Her Magesty's Inspectorate, 1989; Levstik, 2008; Musbach, 2001; National Curriculum Council, 1991; Paxton, 1999; Rouet, Favart, Britt, \& Perfetti, 1997). The absence of an examination of primary sources automatically places the students at a distinct disadvantage and reduces the history course to a mere transmission of another's opinion. The examination of primary sources not only fulfills the three criteria for an effective classroom activity, but it also illuminates the students to the true job of a historian thereby gaining a deeper understanding of the process by which historians compose their own narratives. Several researchers examined the effect of using multiple sources in the secondary classroom and found that students presented with multiple sources demonstrated a high level of engagement and self report of personal enjoyment while studying history (Barton, 1994; Levstik, 1993). Saye and Brush (1999) also reported that students presented with multiple sources were also more likely to become more critical, analytic readers.

Important to note though, is that the simple introduction of primary sources alone will not provide the above benefits. The manner in which a student interacts with the primary source greatly impacts the educational outcome. Simply gazing at a picture of a Civil War battleground will not produce a critical and analytic student. The student must interact with the picture on several levels. The Library of Congress (2002) issued its own criteria for evaluating primary sources. Their criteria require that students first scan the source. The scan, depending on if it is a picture, audio clip, or written document, requires the student use his senses to detect any clues to the sources context or history. The second step in the process requires the student examine the source. Examining the source requires the student take into consideration any information already known about the source, its audience, setting, and purpose. The third step requires a student analyze the source.

Analyzing a source is the attempt to integrate factual observations, prior knowledge, and intuition in an attempt to reconstruct the story behind the source. The last state of 
evaluation requires a student compare the source with another, placing them in context with one another. These evaluative steps deepen a student's understanding of a primary source and facilitate the development of his own analytical and critical thinking skill sets.

Primary sources are unarguably an important asset to the history classroom, but many teachers rely almost exclusively on the history textbook as the primary instructional tool (Banks, 1969; NCSS, 1988; Ravitch \& Finn, 1987; Tyson \& Woodward, 1989). The lack of the introduction of supplemental primary sources then requires one take a closer look at the textbook's use of primary sources. Do textbooks follow criteria similar to that set forth by the Library of Congress when presenting primary sources or are they merely page filler, decorative images only?

\section{The Role of the Textbook in Curriculum}

The swinging pendulum of curricular influence through the decades thrust our educational system into a constant state of change. Regardless of the direction of the swing, the textbook remained, and continues to remain a pivotal element of curriculum. This section of the literature review will discuss the role of textbooks within these curricular changes. As previously discussed, key leaders of various interest groups acting under unique political and social climates drove the curricular changes. Their actions and their endless debates and struggles have transformed curriculum several times and within these changes we also witness the struggle to define the role of the textbook, its purposes, and its level of importance.

Textbooks have always played a critical role in standardizing the curriculum and promoting the current dominant curricular camp. Several studies over the past century stated that students spend a significant amount of their instructional time mastering the textbook (Bagley, 1931; Banks, 1969; Marker \& Mehlinger, 1992; Ravitch \& Finn, 1988; Tyson \& Woodward, 1989; Wade, 1993). Starting as early as 1890, American schools were influenced by what Kliebard (1995) describes as, 'the most profound standardizing influence on the curriculum of the nineteenth-century schools [-] the widespread use of popular textbooks such as the McGuffy reading series and the famous bluebook spellers." These textbooks came to the aid of the ill-educated teachers who relied heavily upon them to determine what to teach. As the prevalence of the textbooks spread, so did the trend of nationalizing curriculum (Ibid). The normal schools of the nineteenth century adopted 
textbooks that emphasized the mind-as-a-muscle metaphor, in which teachers were encouraged to continually exercise the mind as one would a muscle (Thurbayne, 1962). They meant that textbooks promoted drills and recitation as a means of exercising the brain and thereby developing the student. Kilebard suggested that this type of educational approach played into the hand of the ill-educated teachers nicely, as these were individuals capable of very little above these types of exercises.

Additionally, textbooks played a major role in the perpetuation of the notion of the American nation propelled to greatness by the contributions of certain racial groups and a diminished presence of those deemed "racially inferior." Due to the waves of immigration, the various ethnic and racial populations were growing at rapid rates. The massive social and demographic changes due to immigration required Americans to ask the question, "What racial boundaries, if any, mark the national community (Moreau, 2003)?" As a result, the textbooks of the late nineteenth and early twentieth centuries heavily focused on the concepts of race and nation. Socially, doctrines such as scientific racism, Manifest Destiny, and Social Darwinism grew in popularity among the White American communities. Not all textbooks fully embraced these doctrines but they did provide a comforting explanation for brutal courses of action as well as a way to assuage White guilt (Ibid). Textbooks did, however, foster White nationalism as textbook authors chose to focus on the contributions of his ancestors or the contributions of the ancestors of his targeted audience. Some authors like David Saville Muzzey were quite racist in their writings while other authors such as John Fiske took a more tempered approach toward race (Fiske, 1894; Muzzey, 1911). It is fair to say though that a large number of school systems adopted racist textbooks as they accurately reflected popular prejudices (Moreau, 2003). The influence of textbooks on the social impressions of race and the representation of social prejudices still remain quite high and has caused of a whole barrage of research (Fredrickson, 1971; Garcia, 1986; Garcia \& Tanner, 1985; Gossett, 1997; Haller, 1971; Horsman, 1981; Selden, 1999; Takaki, 1979).

While the racial prejudices remained, the mental discipline approach began losing its stronghold due partly to the development of special interest groups and the increasing awareness of the American public regarding social transformation (Kliebard, 1995). The social changes of the decades following the 1890s led to the rapid influx of students enrolled in secondary school systems. Two such changes were the loss of jobs traditionally held by 
teenaged youth due to technological advances and the growth of cities that made schooling more convenient. Curricular evaluation became necessary with this sudden influx of a new and diverse population. Could the schools meet the needs of these students?

Major groups were facing off with one another during the start of the twentieth century. The humanists, social efficiency educators, and social meliorists all debated the central functions of schooling as well as the curricular content (Ibid). Textbooks were under fire as people were afraid many textbooks took a pro-British approach and they feared the textbooks were out to "de-nationalize" our American youth. Trials were held in some of the larger cities around the nation, such as Chicago. Other Americans were also taking aim at textbooks as they felt that textbooks grossly ignored their races and cultures and the pivotal role they played in the development of the American nation (Moreau, 2003), The textbook representation of the American nation as being Anglo-Saxon was deeply offensive. The progressive reforms of the 1920s called upon textbooks to change their content, and textbooks were reluctant to antagonize these new groups who held the power to shape adoption decisions (Ibid). The textbooks gradually changed some of their passages to diminish the strong promotion of the Anglo-Saxon culture and contributions and turned their focus more toward inclusive versions of the White melting pot (Ibid).

The progressive educator and researcher Harold Rugg's found extreme fame and even more extreme notoriety during the decade of the 1930s. His textbooks quickly became among the most popular and in-demand textbooks (Evans, 2007). Ginn and Company, Rugg's textbook publishing company, shipped more than five million of his texts to over five thousand school districts (Moreau, 2003). Rugg's textbooks drastically departed from the mental muscle approach and even the Anglo-centric approach. Instead, he chose to design an integrated curriculum that addressed a common taboo, social class. His textbooks helped to redefine what was acceptable regarding classroom discourse. Class conflict and poverty became issues regularly addressed in the public school classroom due to Rugg's textbooks (Ibid).

Socially and politically, the climates shifted once again. Rugg was persecuted by the opposition and labeled as a communist, un-American (Evans, 2007). Those opposing Rugg and his textbooks claimed that his emphasis of capitalism's defects would only weaken future generation's commitment and belief in free enterprise (Moreau, 2003). Rugg's 
textbook's short-lived welcome reception was all but over by the 1940s, and in their place were textbooks that promoted stronger economic progress and overall positive images of America. Rugg's main focus, poverty, was regulated to the past and severely downplayed in this generation of textbooks (Ibid).

The rise of the Cold War also greatly impacted the direction of the textbook. While still extremely influential regarding the direction of curriculum, the content of the textbook was again adjusted. This time, the "consensus school" limited the range of textbook content (Ibid). Textbooks were examined for leftist politics and communist sympathy. The right greatly shaped the content of the textbooks and therefore the curriculum of the social studies classroom. Social activists, and labor disputes were downplayed and a disembodied government became the primary focus of these postwar textbooks (Ibid). Textbooks became the vehicle for reassurance, positive messages, and a sense of plenty, but as with the changing times, so changed the textbooks.

The activism of the 1960s forced yet more changes to this influential curricular presence. Civil rights movements called for a greater integration of Blacks into the textbook, much like the ethnic minorities did in the 1920s (Ibid). The problem was how to deal with the unpleasant past of slavery without diminishing the grandeur of the American nation? Until this point, textbooks generally only included Blacks in a cursory fashion and tended to focus on their cultural contributions such as music. Textbooks chose to eliminate some stereotypes of Blacks but kept others, thereby perpetuating prejudices. Textbooks removed references and insinuations that Blacks were somehow aggressive, fearful individuals but kept the insinuations that they were powerless (Zimmerman, 2002).

Publishers continued to ultimately promote Southern White sentiment and attempts to incorporate Blacks into the textbook were limited and piecemeal at best. It was not until some of the major cities such as Detroit and New York started to establish their own policies regarding racial diversity in the textbook that textbook companies began to take a more serious look at the treatment of ethnic and cultural minorities (Moreau, 2003). Smaller publishing houses published supplemental texts and fully integrated texts and sold them in significant numbers by 1965 , while the larger publishing companies took a bit longer to reshape their textbooks. Mostly, the concern was with the Southern states and their willingness to utilize such textbooks. 
The 1980s ushered in the era of high stakes testing and a more standardized national curriculum. A Nation at Risk, with its evocative yet common language, polarized a nation and fueled the right to take on curricular reform with renewed fervor. Lax academic standards were to blame for our students' declining academic performance and the public needed to act (Ravitch, 2001). Additionally, multiculturalism was taking root and the cry for greater inclusion of a wide swath of cultures and ethnicities splintered curricular camps even more. Opposition to this standards-based movement stressed the dangers of emphasizing a "common culture" and the ways in which the right tried to define the "official knowledge" students should come in contact with in the public school system (Apple, 1996; Ravitch). In the midst of this conflict were textbooks. Textbook publishers focused their attention to helping students master newly developed standards while still addressing the need to include a greater multicultural presence (Moreau, 2003).

Regardless of the era or the cultural war of the time, the textbook remained the lightening rod for curricular change. The curricular camps knew how potent the textbooks were regarding its influence on school curriculum and sought to control curriculum by controlling the content of the textbook. The ways in which researchers evaluate textbooks are greatly influenced by the current time and the curricular camp with which he/she identifies.

\section{Textbook Evaluation}

The previous sections of the literature review discussed the ways in which history has been taught, the ways in which researchers currently advocate teaching history, and the potent influence of the textbook upon public school curriculum. It has been established that an interactive, creative, and critical approach toward history with the frequent analysis of primary sources best promotes the ways in which an educator should teach history. Unfortunately, this process faces a major complication if the educator relies primarily on an inadequate textbook. How exactly do we determine if a textbook is inadequate? How do we define inadequate? What is the purpose of the textbook? The literature regarding textbook evaluation presents the major areas of focus regarding textbook analysis. These researchers base a textbook's worthiness on the ways in which the textbook addresses their particular area of concern. 
Types of textbook analyses

Textbook evaluations, once a wildly popular area of research, waned in recent years. Those few published studies tended to focus on three different areas: content analysis, comprehension, and social science discipline (Wade, 1993). In describing the first area of focus, content analysis, Siler (1987) noted a subdivision and said the studies fell in one of three subcategories: themes, groups, and historical events. Content analysis simply examines the content of the textbook and each subgroup illustrates the researcher's main area of focus. Studies under the subcategory of themes chose to examine such themes as nuclear war (Fleming, 1983), global coherence (Kinder, Bursuck, and Epstein, 1992), and ideologies (Romansh, 1983). Studies from the group category have waned over the years in favor of comprehension evaluations, but studies still exist in that critique the treatment of minority groups such as women (Clark, Allard, \& Mahoney, 2004; Esposito, 2003; Hahn, Bernard-Powers, Smith Crocco, \& Woyshner, 2007; Hahn \& Blakenship, 1983; Tetreault, 1984) African Americans (Clawson, 2003; Foster, 1999; Garcia \& Tanner, 1985; Wallace \& Allen, 2008), and Native Americans (Lavere, 2005; Richter, 1993; Sanchez, 1999). Others like Sleeter and Grant (1991) choose to look at the treatment of several minority groups. The last subcategory, historical events, contains studies like that of Foster and Nicholls (2005) that examines America in World War II.

Wade (1993) noted that textbook analysis extended beyond content and also examined textbooks on the basis of comprehension. This category primarily includes studies examining the literary aspects of textbooks that impede or enhance student learning and comprehension of main ideas and concepts, though other elements impede or enhance student learning. Studies like McCabe (1993) and Beck and McKeown (1991) examine the considerateness of textbooks. Armburster and Gudbrandeson (1986) and Beck (1991) chose to examine reading comprehension instruction, also classified in this second category. The last category Wade described was the social science discipline category. This category includes studies examining the textbook's general treatment of a particular social science or social science concepts from more than one discipline. Studies such as Holsti (1969), Kniep (1989), and Fredericks, Meinbch \& Rothlein (1993) are just a few of the studies examining textbooks from a cross-discipline approach. 
These main categories describe the different types of textbook analysis studies currently published. All of the major research can be classified according to Wade's groupings and provide illumination regarding the primary basis for their textbook evaluation. With the exception of the comprehension evaluations, textbook evaluations rely heavily on the evaluator's own definition of the nation. Regardless of the fact that many do not even consider the importance of articulating their definition of the nation, the fact remains that their definition remains at the root of their evaluations (Moreau, 2003). A textbook's worthiness is determined by how well it addresses their category of choice. The actual process for evaluation differs from researcher to researcher but a few of the general guidelines are set forth in the following subsection of the literature review.

\section{Textbook analysis methodology}

The methodology for textbook analysis remains somewhat vague and intentionally so. Researchers provide only a general skeleton of methodology and leave great latitudes for the individual researcher in his or her interpretation of the methodology. This subsection will discuss three of the more pivotal textbook analysis methodological discussions.

Falk Pingel (1999) presented a generic method for textbook analysis in the UNESCO Guidebook on Textbook Research and Textbook Revision. In his method, he states that the researcher must first decide who is reviewing the books. Is this the work of a singular individual or a team of evaluators? Once this has been established, the researcher(s) must determine the pedagogical environment in which the textbook is being used. This step works only for a well-defined project and not for textbook analysis in general. For example, if the researcher was commissioned by a school board to evaluate a textbook they wish to implement. The sample must then be defined. How many books will be evaluated? What type of books will be selected for evaluation? The analysis of textbooks follows. Pingel stresses that researchers conduct a didactic analysis of the pedagogy behind the text as well as a content analysis. The last part of the evaluation requires the researcher examine the financial implications of the textbook. What funds are available to produce the text and who can purchase the text? While helpful, these guidelines are so sparse and overly generic that one is left with minimal guidance. 
Robert Stradling (2001) issued his own analytical framework for textbook analysis. He created the following four main categories textbook that evaluators should include in their instruments:

- Textbook content

- Textbook's pedagogical value

- Intrinsic qualities influencing the textbook

- Extrinsic qualities influencing the textbook (Ibid).

The first category examines textbook content, paying special attention to curriculum sequence, omissions, cultural identity, the allocation of space, and the presence or absence of multiple perspectives. The second category examines the textbook's pedagogical value. What is the purported purpose of the book? The third category identifies the intrinsic qualities of the textbook such as author bias. The last category examines extrinsic factors impacting the textbook such as textbook costs. Nicholls (2003) correctly evaluates Stradling's criteria when he stated that Stradling provided a reference point from which to locate oneself, a means of opening further discussion. While a bit more helpful than Pingle, Stradling still only provides general guidelines from which researchers may begin the development of the evaluation instrument.

Perhaps one of the most useful of the generic guidelines comes from the American Textbook Council and its researcher, George Sewell (1994). The American Textbook Council provides an outline for textbook evaluation in which he prescribes the following:

1. Content and Style

a. Examine the table of contents for any patterns of themes

b. Examine one unit to determine if topics are discussed in depth. Does the textbook include a variety of primary sources? Is the narrative lively?

2. Instructional Activities and Teacher Guidance Materials

a. Read over a lesson - compare the materials intended for the teacher and the student

b. Examine the instructional activities for opportunities for active engagement and excellence for students of differing abilities 
c. Examine the teacher's edition - Are primary sources or literature part of the extension? Does the book provide a detailed scope and sequence list for the course?

d. Examine another lesson in the teacher's guide - Again, looking for the same factors as listed above

e. Examine evaluation and assessment materials - Does the textbook suggest formal and informal assessments? Do the assessments foster the development of higher order skill sets? (Ibid).

The lack of sharing among the intellectual community greatly undermines the validity of the textbook analysis instruments and therefore the reliability of the community's conclusions regarding textbooks. Replications simply cannot be conducted without full disclosure of the actual instrument. Another part of the problem regarding textbook evaluation is the lack of a theory with which to ground methodology (Weinbrenner, 1992). The "theory of the schoolbook" remains absent. All of these guidelines provide only a generic methodology for textbook analysis. The researcher is left alone to create an instrument for analysis within the skeleton of this methodology. Many textbook evaluators are quite reluctant, if not completely reluctant, to disclose the detailed instrument and rather choose to provide only general evaluative themes (Sewall, private communication June 12, 2008). The presence of this major gap along with the reliable instrument for measurement and assessment greatly handicaps textbook evaluation research. This troubling state only prolongs that time in which we leave our educators with inadequate information and without the most effective tools necessary to educate our future voters.

\section{Concluding statements}

"Writing history is always political. It always reflects the relations of power in the society. Whose records do we deem worthy of precious shelf space in the archives in libraries? Who has access to these sources or to education in general? Which articles will be published, and whose books reviewed?" (Moreau, 2003)

"History is not just the past and all things that happened in the past, but it is also the record of the past and what one age finds worthy of note in another." (Commager, 1980) 
The above statements apply not only to the field of history but also to the field of education and to the writing and critiquing of secondary history textbooks. Whose point of view/perspective regarding American history should be deemed the most accurate, the most worthy? What content and supplemental materials should textbooks include? In what way should they be represented? History textbook evaluators and critics endlessly debate these issues and authors and publishers struggle to come to some kind of consensus.

The process of writing of American history textbooks always faced great controversy and debate. While many traditionally point to the 1960 s as the time in which American history "lost its way," Moreau (2003) posits that the same educational debates have raged since the creation of American history textbooks, but it is the debates' political and cultural contexts that have changed over the years. Regardless, we are still left to address how the learning of history is done and the existing literature provides little help regarding the inclusion of instructional strategies. Therefore, the author developed an instrument that tries to avoid the criticisms of past content analysis studies that will be able to be replicated by other researchers. This dissertation deliberately avoids the debates on what content to include or eliminate and limits its focus to the examination of primary sources; an important tool all parties agree must be included in the texts to promote the development of critical thinking skill sets, the fostering of democratic citizenship education, as well as an understanding of history (Banks, 1984; Barton, 2008; Cuban, 1993; Davies, Lynch, \& Davies, 2003; Levstik, 2008; Musbach, 2001; Paxton, 1999). 


\section{Chapter 3: Methodology}

\section{Introduction}

The previous chapter examined the existing body of literature regarding the following topics: the historical emphasis of history curriculum, how history should be taught, the role of the textbook in the curriculum, and textbook evaluation. This chapter will proceed from the literature review to the study's methodology. It will examine the textbooks utilized, the development of the instrument as well as its components, and finally the research design.

Textbooks

This dissertation examined the treatment of primary documents in three of the most commonly used, secondary education United States history textbooks adopted by American public schools. The textbooks chosen for this study were identified as some of the most widely adopted textbooks in a list generated by the American Textbook Council (See Table 1). The Council compiles and regularly updates a database of adopted history and social studies textbooks from states such as Texas, California, Indiana, Florida, North Carolina, and New York, all of which have state adoption policies (American Textbook Council, 2008). The Council also monitors and evaluates newly published textbooks from the major publishing companies.

The textbooks chosen for this study were limited to the secondary level, specifically, grade 11. This intentional decision limited the scope of the study as a means of eliminating some of the extraneous variables such as the difference in age appropriate materials, content covered in the textbooks, the students' differing skill sets, and the differing levels of sophistication regarding the students' critical analysis abilities. From the American Textbook Council's generated list, three $11^{\text {th }}$ grade textbooks were randomly selected for review. The names placed into a bag and selected at random. The general characteristics of the sample textbooks are as follows:

- All textbooks were published in the United States

- All textbooks addressed the topic of United States history

- The American Textbook Council identified all of the reviewed textbooks as widely adopted textbooks 
The American Textbook Council listed six $11^{\text {th }}$ grade American history textbooks as the most commonly used textbooks. Choosing three of the six textbooks provided a fairly representative sampling for analysis.

The actual textbooks chosen for evaluation are:

- Nash, G.B. (2002) American Odyssey: The United States in the $20^{\text {th }}$ Century. Ohio: McGraw Hill/Glencoe.

- Boorstin, D.J., Kelley, B.M. (1999). A History of the United States. New Jersey: Pearson/Prentice Hall.

- Ayers, E.L., et. al. (2007). American Anthem. Orlando: Harcourt/Holt.

Description of the textbooks.

Nash, G.B. (2002). American Odyssey: The United States in the $20^{\text {th }}$ Century. Ohio: McGraw Hill/Glencoe.

American Odyssey was first introduced in 1999. The book is in its $2^{\text {nd }}$ edition, released in 2002, and is listed at $\$ 95.96$. The textbook is aimed at a general, secondary audience studying United States history, typically $11^{\text {th }}$ grade students. The textbook provides an accompanying website providing unit activities, interactive tutorial features, links to additional web resources, and current events.

Boorstin, D.J. \&, Kelley, B.M., \& Kelly, B. (1999). A History of The United States, New Jersey: Pearson/Prentice Hall.

A History of The United States was first introduced in 1999. Currently, it is in its $4^{\text {th }}$ edition. The latest edition was published in 2007 and is listed at $\$ 59.97$. The textbook is aimed at a general, secondary audience studying United States history, typically $11^{\text {th }}$ grade students. The textbook does not provide any alternative resources.

Ayers, E.L., et. al. (2007). American Anthem. Orlando: Harcourt/Holt. American Anthem was published in 2007. This is the first edition of the textbook. The publisher provides two versions of the textbook. The first version is a full survey, premier online edition with student edition CD-ROM. It is listed at $\$ 113.66$. The company also provides a full survey book, minus the online edition and CD-ROM for \$107.00. Due to the nature of this study, the latter will be examined. The book is aimed at a general, secondary audience studying United States history, typically $11^{\text {th }}$ grade students. Both 
textbooks include a website providing supplemental materials for each chapter such as quizzes, activities, student resources, and social studies tools.

\section{Instrument}

Little research exists in which clear guidelines for analyzing textbooks are outlined (Nicholls, 2003; Sewall, private communication June 12, 2008), and the review of the literature revealed no research regarding the evaluation of the history textbook's treatment of primary sources or appropriate evaluation instruments. The lack of clear, general criteria as well as the specific nature of this study necessitated the creation of a unique evaluation instrument.

\section{Instrument components}

The majority of the elements included in the textbook evaluation instrument for this study derived from combining the models illustrated by The American Textbook Council (1994), Stradling (2001), and Pingel (1999), all of whom published evaluations of textbooks on topics other than primary document treatment. Incorporated into the evaluation instrument was the primary source evaluation guidelines prescribed by the Library of Congress (Library of Congress, 2002). These quintessential evaluation criteria resurface on numerous other prestigious websites in various forms (National Archives and Records Administration, 2008;NCSS, http://members.ncss.org/se/6707/6707417.pdf) and serve as the benchmark for primary source evaluation. The Library of Congress's evaluation guidelines were chosen because they are proven useful in evaluating primary sources by historians and in history classrooms. This study's instrument incorporated all of the phases of analysis as well as the types of primary sources examined with the Library of Congress's guidelines with the exception of the treatment of audio sources. This intentional exclusion was due to the fact that the study examined only the textbooks and did not address the supplemental materials provided with secondary history textbooks. Many instances abound in which supplemental materials cannot be utilized in the classroom and students must rely solely on the textbook. Financial limitations as well as limited access to computer labs are just a few of the reasons why supplemental materials were not utilized. For this reason, this dissertation focused only on the textbook. Future studies could expand the scope to include such materials. 
Questions that guide students' use of the primary documents are as essential as the presentations of the actual documents. Therefore, the instrument included an analysis of the corresponding questions. This analysis counted the presence of questions and rated the questions' Depth of Knowledge (DOK) level (Webb, 2005). The DOK chart selected for this dissertation was based on a chart created by Webb, with several key words in the level classifications eliminated to fit the needs of this study. Additionally, a new level that linked the depth of analysis with the appropriate level of primary source evaluation set forth by the Library of Congress was added. New sample questions pertained exclusively to the understanding of primary sources or the use of primary sources in assisting student learning replaced the sample questions that Webb included in his diagram.

The instrument included questions that examined the types of primary sources used, the coverage, and placement of the actual primary documents. The instrument recorded the classification and counted incidents of the types of primary source evaluations based on the LOC criteria. Various researchers and higher education professors tested the proposed instrument against the same sample of primary documents and scaffolding questions from the three selected textbooks to obtain an inter-rater reliability for its use (Appendix A).

Relying on the literature, the instrument started as a rough compilation of several key concepts and ideas mentioned in several textbook evaluation studies. These concepts included background information about the textbook, its purpose, audience, information about the stakeholders, pedagogical information, and content analysis. An extensive refining process followed the initial development process. Several additions and modifications were made to the instrument as a consequence of preliminary textbook examination.

Upon a brief examination of the textbooks with the instrument, it was discovered that a distinction between contemporary photographs of ancient sites and the original photographs or images was necessary. Textbooks include both types of photographs, and while both are classified as primary documents in this study, there exists a distinct difference between the two. Also, many textbooks included the presence of paintings from the time period studied. These paintings act as a primary source as they provide the observer with a particular insight of the observed time, much like a journal or a printed book. For this reason, original paintings were included as a primary source. In order for consideration, the paintings must have included documentation from a museum or some other facility capable 
of authenticating the work. Also, in an attempt to consider a painting a first-hand account of an event, a time constraint of a ten-year time limit was appropriate. The refinement process also included the addition of the depth of knowledge classification as well as a category for the use of primary sources as page filler. The textbook examination also illuminated the need to include a section identifying the location of any corresponding question as well as a section for recording the number of instances in which the answers to the corresponding questions were found within the text. If the answer to a question was found in the text, then there is a strong possibility that the students might not analyze the source, but simply accept the answer given, and was noted in the chart. . All of these additions provided data on which to base assumptions regarding the purpose of the primary sources within the evaluated textbook since none of the books provided definitive statements regarding the purpose of primary sources.

\section{Instrument validity}

Prior to data collection, the instrument was sent to five educational researchers and fellow academics in history, education, and psychology (Appendix A). They were given a series of fifteen sample primary sources, the DOK chart and the Library of Congress' primary source evaluation criteria, and were asked to record their primary source classifications, the corresponding questions' LOC and DOK ratings. As Table 1 indicates, the average rater agreement was $78 \%$ for the classification of questions according to the guidelines set forth by the Library of Congress. This suggests that while adequate for this study, future studies should rework some of the operational definitions of each category in an attempt to achieve greater inter-rater reliability. As Table 2 indicates, the average rater agreement was $81 \%$ for the classification of questions according to the Depth of Knowledge chart. This also suggests that for the purpose of this study, the clarification of the categories was sufficient. 
Table 1. Inter-rater reliability numbers and percentages for the classification of corresponding questions according to the guidelines set forth by the Library of Congress

\begin{tabular}{|c|c|c|c|c|c|c|c|}
\hline Primary source & & \multirow{2}{*}{$\begin{array}{l}\text { Scan } \\
\\
0\end{array}$} & \multirow[t]{2}{*}{$\begin{array}{l}\text { Examine } \\
3\end{array}$} & \multirow{2}{*}{$\begin{array}{l}\text { Analyze } \\
1\end{array}$} & \multirow{2}{*}{$\begin{array}{l}\text { Compare } \\
1\end{array}$} & \multirow{2}{*}{$\begin{array}{l}\text { Total } \\
\\
5\end{array}$} & \multirow{2}{*}{$\begin{array}{l}\begin{array}{l}\text { Average } \\
\text { Rater } \\
\text { Agreement } \\
(\%)\end{array} \\
60\end{array}$} \\
\hline Bacon's & Q1 & & & & & & \\
\hline Rebellion & Q2 & 0 & 2 & 3 & 0 & 5 & 60 \\
\hline Battle of & Q1 & 0 & 0 & 4 & 1 & 5 & 80 \\
\hline Lexington & Q2 & 0 & 0 & 0 & 5 & 5 & 100 \\
\hline Common & Q1 & 0 & 5 & 0 & 0 & 5 & 100 \\
\hline Sense & Q2 & 0 & 4 & 1 & 0 & 5 & 80 \\
\hline Constitutional & & 0 & 0 & 5 & 0 & 5 & 100 \\
\hline Farwell & Q1 & 0 & 4 & 0 & 1 & 5 & 80 \\
\hline Address & $\mathrm{Q} 2$ & 0 & 4 & 1 & 0 & 5 & 80 \\
\hline \multirow[t]{2}{*}{ Great Gatsby } & Q1 & 0 & 4 & 1 & 0 & 5 & 80 \\
\hline & Q2 & 0 & 1 & 4 & 0 & 5 & 80 \\
\hline Immigration & Q1 & 1 & 2 & 2 & 0 & 5 & 40 \\
\hline $\mathrm{PC}$ & $\mathrm{Q} 2$ & 0 & 2 & 3 & 0 & 5 & 60 \\
\hline \multirow[t]{2}{*}{ Join or Die } & Q1 & 0 & 1 & 3 & 1 & 5 & 60 \\
\hline & Q2 & 2 & 0 & 3 & 0 & 5 & 60 \\
\hline \multirow[t]{2}{*}{ Leonardo } & Q1 & 0 & 0 & 5 & 0 & 5 & 100 \\
\hline & $\mathrm{Q} 2$ & 1 & 0 & 4 & 0 & 5 & 80 \\
\hline McCain & & 4 & 1 & 0 & 0 & 5 & 80 \\
\hline McGuffey & Q1 & 1 & 0 & 4 & 0 & 5 & 80 \\
\hline Reader & Q2 & 0 & 1 & 4 & 0 & 5 & 80 \\
\hline \multirow[t]{2}{*}{ Menlo Park } & Q1 & 0 & 4 & 1 & 0 & 5 & 80 \\
\hline & Q2 & 0 & 0 & 3 & 2 & 5 & 60 \\
\hline Reagan & Q1 & 0 & 1 & 4 & 0 & 5 & 80 \\
\hline Speech & Q2 & 0 & 0 & 5 & 0 & 5 & 100 \\
\hline \multirow[t]{2}{*}{ Sermon } & Q1 & 0 & 5 & 0 & 0 & 5 & 100 \\
\hline & Q2 & 0 & 2 & 3 & 0 & 5 & 60 \\
\hline \multirow[t]{2}{*}{ WWII Poster } & Q1 & 0 & 4 & 0 & 1 & 5 & 80 \\
\hline & Q2 & 0 & 0 & 4 & 1 & 5 & 80 \\
\hline $\begin{array}{l}\text { Average \% of } \\
\text { rater } \\
\text { agreement }\end{array}$ & & & & & & & $78 \%$ \\
\hline
\end{tabular}


Table 2. Inter-rater reliability numbers and percentages for the classification of corresponding questions according to the Depth of Knowledge criteria

\begin{tabular}{|c|c|c|c|c|c|c|c|}
\hline Primary source & & 1 & 2 & 3 & 4 & Total & $\begin{array}{l}\text { Average } \\
\text { Rater } \\
\text { agreement } \\
(\%)\end{array}$ \\
\hline Bacon's & Q1 & 3 & 2 & 0 & 0 & 5 & 60 \\
\hline Rebellion & Q2 & 0 & 1 & 4 & 0 & 5 & 80 \\
\hline Battle of & Q1 & 1 & 1 & 3 & 0 & 5 & 60 \\
\hline Lexington & Q2 & 0 & 0 & 0 & 5 & 5 & 100 \\
\hline Common & Q1 & 4 & 1 & 0 & 0 & 5 & 80 \\
\hline Sense & Q2 & 1 & 3 & 0 & 1 & 5 & 60 \\
\hline Constitutional & & 0 & 0 & 5 & 0 & 5 & 100 \\
\hline Farwell & Q1 & 2 & 2 & 0 & 1 & 5 & 40 \\
\hline Address & Q2 & 1 & 2 & 2 & 0 & 5 & 40 \\
\hline \multirow[t]{2}{*}{ Great Gatsby } & Q1 & 4 & 1 & 0 & 0 & 5 & 80 \\
\hline & $\mathrm{Q} 2$ & 1 & 0 & 4 & 0 & 5 & 80 \\
\hline Immigration & Q1 & 1 & 0 & 4 & 0 & 5 & 80 \\
\hline $\mathrm{PC}$ & Q2 & 0 & 1 & 4 & 0 & 5 & 80 \\
\hline \multirow[t]{2}{*}{ Join or Die } & Q1 & 5 & 0 & 0 & 0 & 5 & 100 \\
\hline & Q2 & 0 & 0 & 4 & 1 & 5 & 80 \\
\hline \multirow[t]{2}{*}{ Leonardo } & Q1 & 0 & 5 & 0 & 0 & 5 & 100 \\
\hline & $\mathrm{Q} 2$ & 0 & 0 & 5 & 0 & 5 & 100 \\
\hline McCain & & 5 & 0 & 0 & 0 & 5 & 100 \\
\hline McGuffey & Q1 & 0 & 1 & 4 & 0 & 5 & 80 \\
\hline Reader & Q2 & 0 & 0 & 5 & 0 & 5 & 100 \\
\hline \multirow[t]{2}{*}{ Menlo Park } & Q1 & 0 & 5 & 0 & 0 & 5 & 100 \\
\hline & Q2 & 0 & 0 & 5 & 0 & 5 & 100 \\
\hline \multirow[t]{2}{*}{ Reagan Speech } & Q1 & 4 & 0 & 1 & 0 & 5 & 80 \\
\hline & Q2 & 0 & 0 & 5 & 0 & 5 & 100 \\
\hline \multirow[t]{2}{*}{ Sermon } & Q1 & 4 & 0 & 1 & 0 & 5 & 80 \\
\hline & Q2 & 0 & 4 & 0 & 1 & 5 & 80 \\
\hline \multirow[t]{2}{*}{ WWII Poster } & Q1 & 4 & 1 & 0 & 0 & 5 & 80 \\
\hline & $\mathrm{Q} 2$ & 0 & 0 & 3 & 2 & 5 & 60 \\
\hline $\begin{array}{l}\text { Average } \% \text { of } \\
\text { rater agreement }\end{array}$ & & & & & & & $81 \%$ \\
\hline
\end{tabular}

As Table 3 indicates, there was a significant, moderate positive Pearson correlation between the Library of Congress guidelines and the Depth of Knowledge criteria $\left[\mathrm{r}_{\mathrm{xy}}(138)=\right.$ $.50, \mathrm{p}<.01]$. A correlation of this strength between two independent items suggests that with some minor clarifications of the categorical operational definitions for the guidelines set forth by the Library of Congress, the two categories could be used interchangeably, one in favor of the other. 
Table 3. Correlations Between LOC and DOK Categorizations for In-text Questions

\begin{tabular}{|l|l|l|l|}
\hline \multicolumn{2}{|c|}{} & LOC & DOK \\
\hline \multirow{7}{*}{} & $\begin{array}{l}\text { Pearson } \\
\text { Correlation }\end{array}$ & 1 & $.499 * *$ \\
\cline { 2 - 4 } & $\begin{array}{l}\text { Sig. (2- } \\
\text { tailed) }\end{array}$ & & .000 \\
\cline { 2 - 4 } & $\mathrm{N}$ & 140 & 140 \\
\hline \multirow{1}{*}{ DOK } & $\begin{array}{l}\text { Pearson } \\
\text { Correlation }\end{array}$ & $.499 * *$ & 1 \\
\cline { 2 - 4 } & $\begin{array}{l}\text { Sig. (2- } \\
\text { tailed) }\end{array}$ & .000 & 140 \\
\cline { 2 - 4 } & $\mathrm{N}$ & 140 & \\
\hline
\end{tabular}

** Correlation is significant at the 0.01 level (2-tailed)

\section{Data Collection}

The actual data collection was conducted during the spring of 2009. Upon completion of data collection, descriptive statistical analyses for each of the categories in sections 1 and 2 of the instrument were conducted. The data represented in both table and graphical formats identified patterns, trends, or themes in the data and acted as a way to report concrete information. From the quantitative data, the framed narrative descriptions of the data were created, which are included in the discussion.

\section{Research Design}

This dissertation conducted both quantitative and qualitative analyses of the data gathered from the instrument. The quantitative analysis was conducted first as a means of guiding and directing the qualitative component.

\section{Quantitative analysis}

The data gathering process was conducted by using the created textbook evaluation instrument (Appendix B). The entirety of each of the three textbooks was evaluated and the results recorded on the instrument. A survey was prepared primarily by incorporating elements of three major instrument studies, the Library of Congress' primary source evaluation guidelines, and the DOK level of analysis chart, and then the instrument was modified so it specifically addressed the treatment of primary sources. An initial review of the textbooks revealed that the instrument required further refinement regarding the primary source categories, and the instrument was expanded accordingly. 


\section{Framing}

One of the ways researchers examined competing perspectives was to utilize a frame. Entman (2004) defined framing as "[a process of] selecting and highlighting some facets of events or issues, and making connections among them so as to promote a particular interpretation, evaluation, and/or solution." Political, cultural, economic, and ideological differences play a large role in the differences in the perspectives and subsequent framings. The framing literature, as it pertains to curriculum change, was minimal (Binder, 2002; Camicia, 2008) but quite useful. Framing helped to organize and describe the ways in which the various stakeholders in social studies curriculum categorized issues as controversial as well as how the contexts and interpretations of historical events mediated this process (Camicia).

Following the quantitative analysis, a categorization of the data was conducted. The data was explained and evaluated through a narrative description, included in the discussion. The qualitative narrative discussed each textbook's philosophy of teaching and the presentation of primary sources, possible inferences regarding the role of the teacher in the implementation of the use of primary sources found within the text, as well as the specific ways in which each of the textbooks presents or assists the reader in the utilization of primary sources. This included the locations of the primary sources' corresponding questions and how, if at all, these questions aid the student's understanding of history or development of critical analysis skill sets. A comparison between the three textbooks was also constructed. Lastly and most importantly, the ways in which the differing stakeholders would perceive the usefulness of the textbooks were described.

\section{Implications}

From these analyses, conclusions on how primary sources are presented in textbooks are given to provide some recommendations to the publishers of these textbooks on the ways in which they can improve their utilization of primary sources. The implications of this study are beneficial for researchers, teachers, teacher educators, and most importantly, the students. With research regarding the textbook's treatment of primary sources, researchers can gain more insight into the history textbook, and promoting the expansion of future textbook evaluation research. Proper use of primary sources has the potential of providing numerous educational benefits, but in order to get to this point, we must begin with a 
systematic analysis of the materials used in the classroom. An awareness of the benefits or limitations of a textbook regarding its use of primary sources provides teachers with a stronger starting point regarding curriculum development. This analysis will help a teacher determine if outside sources are necessary or even if they need to supplement their own educational background to provide students with lessons that require analyzing primary sources. Teacher educators can benefit from these findings as well. The findings inform teacher educators of the current primary source analysis capabilities provided by several of the most commonly used American history textbooks. This information can help them better adjust their own curriculum regarding social studies methodology. Finally, students can benefit from these findings, as their teachers will hopefully adjust their lessons so that students can be encouraged to learn to analyze primary sources and could possibly develop those critical skill sets.

\section{Concluding statements}

This section of the dissertation provided the rationale for and outlined this study's methodology. This chapter also examined the specific components of the study's reliable instrument and the process by which reliability was determined. The following section will report the results from the textbook analysis. 


\section{Introduction}

\section{Chapter 4: Results}

The previous chapter outlined the study's methodological background and the process by which the study's instrument was created. This comprehensive instrument incorporated suggestions from a variety of previous researchers in hopes of creating a more transparent description of what to examine in a textbook analysis. This chapter will discuss the results of the textbook evaluation. First, a general overview of each textbook including information gathered through categories 3, 4, and 5 of the instrument will be reported. The third category of the instrument asked questions regarding the purported pedagogical approach of the textbook and the use of primary sources. The fourth category examined the intrinsic qualities of the textbook and the fifth category examined the extrinsic factors of the textbook.

Following these reports, the information gathered through categories 1 and 2 of the instrument will be reported. The first category included general information about the location of the various primary sources' corresponding questions. The second category examined the primary source content, specifically, how often the primary sources' corresponding questions utilized various elements of the Library of Congress' guidelines for primary source analysis as well as an evaluation of these questions according the Depth of Knowledge criteria.

The Library of Congress' guidelines for primary source evaluation state that an individual should SCAN the source for any contextual clues as well as the state of the source, EXAMINE the source for its intended audience and purpose, ANALYZE the source by integrating factual observations and prior knowledge to reconstruct the story behind the source, and COMPARE the source with another primary source. The Depth of Knowledge criteria classified questions into one of four categories. The first category, corresponding with LOC Scan, consisted of basic who, what, when, where, and why questions. The second category, corresponding with LOC examine, consisted of questions that asked an individual to summarize, group, and classify. The third category, corresponding with LOC analyze, consisted of questions that asked an individual to analyze, synthesize, and critique. The fourth category, corresponding with the LOC compare, consisted of questions that asked an individual to create a new synthesis or compare with another source. 
This study only sought to examine the treatment of primary sources in regards to the types of corresponding questions. A second category in the instrument included the presence of ethnic groups, gender classifications, religious groups, political groups, and key historical figures in the primary sources and their corresponding questions. While of worthy consideration, data in this section are not necessary to effectively answer the questions of the current study and therefore, will not be reported.

Description of Selected Textbooks

American Odyssey (AO)

Background information

American Odyssey, a U.S. history textbook intended for an $11^{\text {th }}$ grade audience, was first published in 1999, and the McGraw-Hill Companies, Inc published the current edition in 2002. The book retails for $\$ 95.96$ and is accompanied by an interactive website providing unit activities, interactive tutorial features, links to additional resources, and current events.

Author and contributing editors

Gary B. Nash authored the book along with several consultants. At the time of press, Gary B. Nash was a professor of history at the University of California at Los Angeles. Christopher L. Salter from the University of Missouri served as the geography consultant, while Allan H. School, a former Secondary Social Science Specialist from the Office of Instruction with the Los Angeles Unified School District, served as the educational consultant. Several other consultants included:

- Multicultural Education: Gloria Contreras, Professor of Secondary Education, University of Texas

- American West Frontiers: Albert L. Hurtado, Associate Professor of History, Arizona State University

- Reading and Bilingual Education: Eileen Mortensen, Assistant Professor of Education, National Louis University

- Women's Studies and African American History: Cheryl Johnson Odim, Assistant Professor of History

- Asian Studies: Gary Okihiro, Associate Professor of History, Cornell University 
- African American History: Julius S. Scott, Assistant Professor of History, Duke University

- Mexican American Women's History: Vicki L. Ruiz, Professor of Women's Studies, Arizona State University

- Native American History: John Waukechan, Member - American Indian Resource and Education Coalition

As with most textbooks, McGraw-Hill relied on numerous content and educational reviewers. Of the 15 content reviewers, 9 were professors from university-level history departments; 2 belonged to political science departments; 1 belonged to a department of history and political science; 1 with the Arabic and Islamic Studies department; 1 with the School of Humanities; and 1 served as the director of the Family and Community History Center at the Newberry Library. Of the 18 educational reviewers, all 18 were affiliated with public, secondary institutions. Three were from Illinois; 3 from California; 2 from West Virginia and Illinois, respectively; and 1 from New York, Massachusetts, Connecticut, Pennsylvania, New Jersey, Florida, Texas, and Minnesota, respectively.

Additional Stakeholders

In addition to the above-mentioned stakeholders, at the time of press, The McGrawHill Companies, Inc. principal corporate executives were as follows:

- Chairman, President, and Chief Executive Officer - Harold McGraw III At the time of press, Mr. McGraw served on the Board of Directors of United Technologies and ConocoPhillips. He also served as the chairman of Business Roundtable; chairman of the Emergency Committee for American Trade (ECAT); on the board of the United States Council for International Business; and was a member of the Business Council. Additionally, Mr. McGraw was a member of the State Department's Advisory Committee of Transformational Diplomacy and the U.S. Trade Representative's Advisory for Trade, Policy, and Negotiations (ACTPN) (Ibid). Regarding Mr. McGraw's involvement with community outreach, at the time of press he was involved with Carnegie Hall, the Council for Economic Education, the New York Public Library, National Organization on Disability, National Academy Foundation, Partnership for New York City, Prep for Prep, and the Council for Industry and Higher Education in London. He was also the chairman of 
the Committee Encouraging Corporate Philanthropy (Ibid). The McGraw family's close personal and professional ties with former Presidents George W. Bush and George H.W. Bush presented additional biases, though most of those concerns resided with reading and literacy programs and the subsequent profits gained from the outcomes of the No Child Left Behind initiatives (Metcalf, 2002).

- Executive Vice President, Chief Financial Officer - Robert J. Bahash

- Executive Vice President, Chief Information Officer - Bruce D. Marcus

- Executive Vice President, Human Resources - David L. Murphy

- Executive Vice President, Corporate Affairs, Executive Assistant to the Chairman, President and Chief Executive Officer - D. Edward (Ted) Smyth

- Executive Vice President, Global Strategy - Charles L. Teschner, Jr.

- Executive Vice President and General Counsel - Kenneth M. Vittor (www.mcgrawhill.com/aboutus/profiles.shtml, accessed on March 15, 2009).

Additionally, at the time of press, the principal operations executives were as follows:

Deven Sharma, President Standard \& Poor's; Peter C. Davis, President McGraw-Hill Education; and Glenn S. Goldberg, President Information \& Media (Ibid).

Textbook description

The textbook was divided into 10 chronologically organized units and contained several additions called "features." The features, located at various points throughout each unit, included a primary sources library, a section located at the end of the textbook displaying a variety of primary sources that correspond to the various chapters. Two pages of primary sources and interpretative questions were devoted to two units divisions. The section also included two pages devoted to instructional directives assisting the students with the task of working with primary sources. The textbooks classified primary sources using the following categories: printed publications, personal records, visual materials, oral histories, songs \& poems, and artifacts. Additionally, the textbook noted the availability of additional primary sources on a CD-ROM. This disc was not evaluated during the study and future studies may want to include such an analysis. The other features - case study; literature; one day in history; culture of the time; then and now; science, technology \& society; geography, impact on history; and skills all featured some primary sources, but they were utilized in differing ways and served different purposes. The textbook lacked an 
introduction; therefore the purported purpose of the book and the use of primary sources could not be ascertained.

American Anthem (AA)

Background information

The Holt, Rinehart and Winston division of A Harcourt Education Company, a U.S. history textbook intended for an 11th grade audience, first published American Anthem, in 2007. Since the book's publication, Holt, Rinehart and Winston merged with McDougal Littell to become Holt McDougal, a division of Houghton Mifflin Harcourt. Education Media and Publishing Group (EMPG) controlled Houghton Mifflin Harcourt. Houghton Mifflin Harcourt also received licensing fees from Educational Media and Publishing Group International (EMPGI) for exclusive overseas non-English reproduction rights (http://www.irishtimes.com/newspaper/finance/2008/1021/1224454424762.html, retrieved on June 1, 2009). The publisher printed two versions of the textbook. The first version, full survey, premier online edition, came with a student edition CD-ROM. It was listed at \$113.66. The second book, full survey book minus the CD-ROM, was listed at \$107.00. This study utilized the second version of the textbook.

Authors and contributing editors/consultants

The book was co-authored by Edward L. Ayers, Jesús F. de la Teja, Deborah Gray White, and Robert Schulzinger. At the time of press, Edward L. Ayers was the Dean of the College and Graduate School of Arts \& Sciences at the University of Virginia. Jesús F. de la Teja was the chair of the history department at Texas State University at San Marcos, Texas. Deborah Gray White was the Distinguished Professor of History at Rutgers University. Robert Schulzinger was the Director of the International Affairs Program and Professor of History at the University of Colorado, Boulder. Sam Wineburg, Professor of Education at Stanford University, served as the textbook's Senior Program Consultant. Several other consultants were also listed. They are as follows:

- Program Consultant - Kylenne Beers, Senior Reading Researcher, Yale University

- Academic Consultant: Senior Religion Consultant - John Ferguson, Assistant Professor of Political Science/Criminal Justice, Howard Payne University

- Academic Consultant: Constitutional Law Consultant - Gregory Massing, Adjunct Professor, Boston College Law School 
- Academic Consultant: Geography Consultant - Walter Schroeder, Assistant Professor Emeritus of Geography

Several other individuals contributed to the book as one of four categories of contributors. The first category, academic reviewers, was comprised of four professors of history from across the nation. The second category, senior writing consultant, was Mr. Peter Lacey. The third category, educational reviewers, was comprised of 10 in-service teachers from a variety of states. There were 3 teachers representing California, 2 representing North Carolina, and 1 from Illinois, Indiana, Pennsylvania, New York, and Virginia, respectively. The fourth category, field test teachers, was comprised of 9 in-service teachers. There were 3 representing Ohio, and one representing Texas, Michigan, California, North Carolina, and New York, respectively.

Additional stakeholders

In addition to the above-mentioned stakeholders, at the time of press, the Board of Directors was as follows:

- Chief Executive Officer - Barry O'Callaghan served as the Chief Executive At the time of press, Mr. O'Callaghan was the Chairman and the largest shareholder of Education Media and Publishing Group (EMPG) and the Chairman of Education Media and Publishing Group International (EMPGI). He previously served as the CEO of Riverdeep and initiated a reverse merger between Riverdeep and Houghton Mifflin Company. He also worked to acquire Harcourt Education, Harcourt Trade and the Greenwood-Heinemann divisions of Reed Elsevier (http://www.milkeninstitute.org/events/gcprogram.taf?function=bio\&EventID=GC0 9\&SPID=4148, accessed on June 1, 2009). He has also worked as an international investment banker in London, New York, and Hong Kong for both Morgan Stanley and Credit Suisse (http://web.riverdeep.net/portal/page?_pageid=813,1374328\&_dad=portal\&_schema =PORTAL, retrieved on June 1, 2009).

- Executive Vice President and Chief Financial Officer - Michael Muldowney

- Executive Vice President and General Counsel - Bill Bayers

- Executive Vice President and Chief Human Resources Officer - Ciara Smyth 
- President, Houghton Mifflin Harcourt Trade and Reference Publishers. - Gary Gentel

Prior to his position as President, Houghton Mifflin Harcourt Trade \& Reference Publishers, Gary Gentel served as the Corporate Vice President of Sales for Houghton Mifflin (http://www.publishersweekly.com/article/CA6513591.html, retrieved on June 1, 2009).

- President, K-12 Publishers - Michael Lavelle

- Executive Vice President, Content Development and Publishing, K-12 Publishers Bethlam Forsa

- Executive Vice President, Strategy, K-12 Publishers - Scott Kirkpatrick

- Senior Vice President, Operations - Greg DuMont

- Senior Vice President, Digital Products Research and Development, K-12 Publisher - Fiona O'Carroll

- Senior Vice President, Sales and Marketing, K-12 Publishers - Rita Schaefer

- Senior Vice President and Chief Accounting Officer - Mark Schumacher (http://www.hmhco.com/leadership.html, retrieved on June 1, 2009)

Textbook description

American Anthem was divided into 10 units, organized chronologically. This textbook provided a features index that separated several key features into their own categories. The features noted were document-based investigations, primary sources, political cartoons, American literature, counterpoints, faces of history, history close-up, linking to today, landmark Supreme Court cases, tracing history, history \& geography, and American liberty. Each feature section was intended to be an interactive feature for the students and was imbedded within the various units. Additionally, the textbook provided another index section that listed maps, charts and graphs, and primary sources. These sources may or may not be accompanied with an interactive component. It should be noted that while the textbook did provide such lists, they did not list every primary source included in the textbook.

The textbook, while lacking an introduction, did provide the reader with a section titled, "Reading like a historian." In this section, Sam Wineburg colloquially discussed the ways in which the reader should approach the textbook. He suggested that the reader be a 
history detective by asking questions, though he did not provide examples of the types of questions a reader should ask. He also explained that the meaning of facts was greatly determined by the type of source, and the opinions of the varied experts. He also explained how to read like a historian. By this, he meant that the reader should pay attention to the Points of View and Counterpoint features as well as work to identify perspectives and details.

The textbook also included a Skills Handbook that identified several key skills the reader should possess and how to hone those skills. The handbook came before the actual units. Some of the skills included were organized into three groups - reading skills, social studies skills, and reading like a historian. The reading skill activities were: becoming an active reader; building vocabulary; identifying main ideas and details; summarizing; making interfaces; sequencing; identifying cause and effect; comparing and contrasting; identifying problem and solution; drawing conclusions; and making generalizations. The social studies skills were: interpreting time lines; interpreting charts; interpreting pie and bar graphs; interpreting line graphs; interpreting infographics; interpreting movement maps; interpreting historical maps; interpreting cartograms; analyzing cost and benefits; and evaluating information on the Internet. The reading like a historian skills were: major historical concepts; themes of history; analyzing primary sources; analyzing visuals; interpreting political cartoons; interpreting literature as historical evidence; recognizing bias; evaluating sources; analyzing secondary sources; analyzing bias in historical interpretation; evaluating historical interpretation; analyzing alternative interpretations of the past; making oral presentations; and making writing presentations.

Following the units, the textbook included several additional sections. Key events in American history, Supreme Court decisions, a biographical dictionary, geography and map skills handbook, a primary source library, and a glossary listed in both English and Spanish. The primary source library provided 24 written documents from various points in American history. No corresponding questions were provided.

\section{A History of the United States (AH)}

Background information

A History of the United States, a U.S. history textbook intended for an $11^{\text {th }}$ grade audience, was first published in 1999, and the current edition was published in 2007 by Prentice Hall. The book retails for $\$ 59.97$. There were no supplemental resources provided. 
Authors and editorial associate

Daniel Boorstin and Brooks Mather Kelley authored the book along with the Editorial Associate, Ruth Frankel Boorstin. At the time of press, Daniel Boorstin, a Pulitzer Prize winner, served as The Library of Congress Emeritus. Brooks Mather Kelley was a Research Affiliate in History at Yale University. Ms. Suzzanne Gray Kelley was listed as a researcher, typist, and editor. There were no researchers, consultants, or other evaluators listed.

According to the textbook, prior to his position as The Library of Congress Emeritus, Daniel Boorstin served as the Director of the Library of Congress, the Director of the National Museum of American History and Technology, and the Senior Historian of the Smithsonian Institution. Boorstin has also published numerous historical books. Prior to his position at Yale, Brooks Mather Kelley served as University Archivist and Curator of Historical Manuscripts at Yale, a Professor of American History and the Illinois Institute of Technology, and as a Visiting Professor at Brown University. Kelley has also served as a political consultant for "Freedom to Speak," a Public Broadcasting Services television series, and as the president of the Connecticut Fund for the Environment.

Additional stakeholders

In addition to the above-mentioned stakeholders, at the time of press, Pearson, the parent company of Prentice Hall listed its Board of Governors as follows:

- Chairman, Glen Moreno. Mr. Moreno is also the director of Fidelity International and a senior independent director of Man Group plc. Prior to his position as Chairman, he served as the Chief Executive of Fidelity International, several positions within Citigroup, a trustee to The Prince of Liechtenstein and Liechtenstein Global Trusts, and as the governor of The Ditchley Foundation.

- Chief Executive - Marjoire Scardino

- Chief Financial Officer - Robin Freestone

- Chief Executive, North American Education - Will Ethridge

- Chief Executive, Financial Times Group - Rona Fairhead Chairman and Chief Executive, Penguin - John Makinson (http://www.pearson.com/index.cfm?pageid=16, retrieved on June 1, 2009) 


\section{Textbook description}

The textbook began with a brief note on American pictorial art. This note articulated the authors' explicit intention to include artwork as a means of helping the reader study the past. Following the note, the prologue stated that this textbook's purpose was to help the reader determine what it means to be an American. There was no purported purpose of the primary sources outside of the pictorial art's purpose to help the reader study the past. The process by which the authors attempted to answer this question was to examine our earlier selves. The textbook also included indexes of maps, charts and graphs, and primary sources. It should be noted that this study expanded beyond the authors' index of primary sources.

The body of the textbook was arranged into 12 chronologically organized units. Each unit concluded with a Making Connections section. This section included two pages with a timeline of events in American and World History along with a few key visual pieces and a very brief review of the unit. The section also included the main themes in history the authors felt permeated the unit.

Following the body of the textbook was an epilogue about the future; a series of political maps of the United States, North America, Africa, Asia, Europe, Central American and the Caribbean, and the world; a list of the Presidents and Vice Presidents of the United States of America; The Declaration of Independence and Constitutional Amendments with narrative explanations; and a glossary of key terms.

\section{Concluding statements}

The involvement of the authors for each of the textbooks seemed to vary given the number of contributing editors and other consultants, though this could not be confirmed by any of the textbook companies. The prices of the textbooks also varied with Boorstin's textbook listed as the cheapest by a considerable margin. The other two textbooks were quite comparable in price. Boorstin also lacked a supplemental CD-ROM or an accompanying website while the other two books provided the students with such materials.

There were several similarities among the textbooks' presentations. Each textbook arranged their units according to chronological order, and all used a separate index to identify a selection of primary sources. A variety of authors, consultants, and reviewers whose credentials revealed a wide range of knowledge and expertise in teaching U.S. 
history were also utilized. Additionally, major corporations whose board members also served on various corporate boards and commissions published the textbooks. Important this study was that all three textbooks also lacked a clearly articulated purpose for the use of primary sources though Boorstin hinted at the purpose of better understanding history and Ayers of thinking more like a historian.

An overview of the textbooks revealed that each textbook addressed primary sources in different fashions. To better understand the examined textbooks' treatment of primary sources, organizational tables were created for each major topic. Table 4 displays the raw data and percentages for the location of the primary sources' corresponding questions. Table 5 displays the raw data and percentages for the primary sources' corresponding questions' DOK classification. Table 6 displays the raw data and percentages for the primary sources' corresponding questions' LOC classification. Table 7 displays the raw data and percentages of the corresponding questions with answers found in the text. Table 8 displays the raw data and percentages of primary sources classified as page filler. Each table will be presented and its findings discussed.

Description of Primary Sources

\section{Location of questions}

Table 4 shows the raw data and percentages for the locations of the corresponding questions for each of the various primary sources. Data from all three textbooks are listed in this table. 
Table 4. Raw Data and Percentages for the Locations of the Corresponding Questions by Textbook

\begin{tabular}{|c|c|c|c|c|c|c|c|c|c|c|c|c|c|c|}
\hline & & Under & $\begin{array}{l}\text { Under } \\
\%\end{array}$ & None & $\begin{array}{l}\text { None } \\
\%\end{array}$ & Prior & $\begin{array}{l}\text { Prior } \\
\%\end{array}$ & $\begin{array}{l}\text { Else on } \\
\text { page }\end{array}$ & $\begin{array}{l}\text { Else on } \\
\text { page \% }\end{array}$ & $\begin{array}{l}\text { End } \\
\text { chap }\end{array}$ & $\begin{array}{l}\text { End } \\
\text { chap \% }\end{array}$ & $\begin{array}{l}\text { End } \\
\text { book }\end{array}$ & $\begin{array}{l}\text { End } \\
\text { book \% }\end{array}$ & Total \\
\hline \multirow{3}{*}{$\begin{array}{l}\text { Written } \\
\text { docs }\end{array}$} & $\mathrm{AO}$ & 13 & 5.2 & 225 & 90.4 & 4 & 2 & 6 & 2 & 1 & .04 & 0 & 0 & 249 \\
\hline & AA & 105 & 34.5 & 182 & 60 & 17 & 5.5 & 0 & 0 & 0 & 0 & 0 & 0 & 304 \\
\hline & $\mathrm{AH}$ & 0 & 0 & 78 & 100 & 0 & 0 & 0 & 0 & 0 & 0 & 0 & 0 & 78 \\
\hline \multirow{3}{*}{$\begin{array}{l}\text { Contemp. } \\
\text { photo }\end{array}$} & $\mathrm{AO}$ & 2 & 100 & 0 & 0 & 0 & 0 & 0 & 0 & 0 & 0 & 0 & 0 & 2 \\
\hline & AA & 0 & 0 & 0 & 0 & 0 & 0 & 0 & 0 & 0 & 0 & 0 & 0 & 0 \\
\hline & $\mathrm{AH}$ & 0 & 0 & 5 & 100 & 0 & 0 & 0 & 0 & 0 & 0 & 0 & 0 & 5 \\
\hline \multirow[t]{3}{*}{ Artwork } & $\mathrm{AO}$ & 12 & 9.45 & 114 & 89.76 & 1 & 0.79 & 0 & 0 & 0 & 0 & 0 & 0 & 127 \\
\hline & AA & 19 & 44.19 & 24 & 55.81 & 0 & 0 & 0 & 0 & 0 & 0 & 0 & 0 & 43 \\
\hline & $\mathrm{AH}$ & 0 & 0 & 183 & 100 & 0 & 0 & 0 & 0 & 0 & 0 & 0 & 0 & 183 \\
\hline & $\mathrm{AO}$ & 11 & 31.43 & 19 & 54.28 & 5 & 14.29 & 0 & 0 & 0 & 0 & 0 & 0 & 35 \\
\hline \multirow{2}{*}{ cartoon } & AA & 38 & 80.85 & 5 & 10.64 & 4 & 8.51 & 0 & 0 & 0 & 0 & 0 & 0 & 47 \\
\hline & $\mathrm{AH}$ & 0 & 0 & 31 & 100 & 0 & 0 & 0 & 0 & 0 & 0 & 0 & 0 & 31 \\
\hline Original & $\mathrm{AO}$ & 13 & 3.27 & 383 & 96.47 & 1 & 0.26 & 0 & 0 & 0 & 0 & 0 & 0 & 397 \\
\hline \multirow[t]{2}{*}{ photos } & AA & 6 & 42.86 & 7 & 50 & 1 & 7.14 & 0 & 0 & 0 & 0 & 0 & 0 & 14 \\
\hline & $\mathrm{AH}$ & 0 & 0 & 270 & 100 & 0 & 0 & 0 & 0 & 0 & 0 & 0 & 0 & 270 \\
\hline Images of & $\mathrm{AO}$ & 1 & 2.78 & 35 & 97.22 & 0 & 0 & 0 & 0 & 0 & 0 & 0 & 0 & 36 \\
\hline \multirow[t]{2}{*}{ Artifacts } & AA & 2 & 28.57 & 5 & 71.43 & 0 & 0 & 0 & 0 & 0 & 0 & 0 & 0 & 7 \\
\hline & $\mathrm{AH}$ & 0 & 0 & 25 & 100 & 0 & 0 & 0 & 0 & 0 & 0 & 0 & 0 & 25 \\
\hline Historic & $\mathrm{AO}$ & 1 & 100 & 0 & 0 & 0 & 0 & 0 & 0 & 0 & 0 & 0 & 0 & 1 \\
\hline \multirow[t]{2}{*}{ Maps } & AA & 0 & 0 & 0 & 0 & 0 & 0 & 0 & 0 & 0 & 0 & 0 & 0 & 0 \\
\hline & $\mathrm{AH}$ & 0 & 0 & 6 & 100 & 0 & 0 & 0 & 0 & 0 & 0 & 0 & 0 & 6 \\
\hline Total & & 224 & 12.04 & 1596 & 85.81 & 33 & 1.78 & 6 & 0.32 & 1 & .05 & 0 & 0 & 1860 \\
\hline
\end{tabular}


As Table 4 indicates, of the 1860 instances, a vast majority of the primary sources lacked any corresponding questions $(85.81 \%)$. For those corresponding questions asked, the predominant location was directly below the source $(12.4 \%)$. The least common location was at the end of the book (0\%). Excluding A History of the United States, which lacked any corresponding questions, both American Odyssey and American Anthem's corresponding questions were predominately located directly under the primary source. American Odyssey's corresponding questions for the written documents were the most diverse regarding their locations with $13(5.2 \%)$ located directly under the source, $4(2 \%)$ located on either the prior or following page, $6(2 \%)$ located elsewhere on the same page, and 1 (.04) question located at the end of the chapter. American Anthem lacked any corresponding questions for historical maps and contemporary photographs of ancient/historic sites, but the majority of its remaining primary sources' corresponding questions followed the aggregate trend.

\section{Depth of Knowledge}

Table 5 shows the raw data and percentages for the primary sources' corresponding questions' DOK level. The data for each type of primary source has been recorded for each of the textbooks. 
Table 5. Raw Data and Percentages for the Primary Sources' Corresponding Questions' Depth of Knowledge (DOK) Level by Textbook

\begin{tabular}{|c|c|c|c|c|c|c|c|c|c|c|}
\hline & & DOK & $\mathrm{DOK}$ & $\mathrm{DOK}$ & DOK & $\mathrm{DOK}$ & DOK & DOK & DOK & Total \\
\hline & & 1 & $1 \%$ & 2 & $2 \%$ & 3 & $3 \%$ & 4 & \multicolumn{2}{|l|}{$4 \%$} \\
\hline \multirow{3}{*}{$\begin{array}{l}\text { Written } \\
\text { docs }\end{array}$} & $\mathrm{AO}$ & 11 & 45.83 & 0 & 0 & 13 & 54.17 & 0 & 0 & 24 \\
\hline & $\mathrm{AA}$ & 52 & 42.62 & 28 & 22.95 & 38 & 31.15 & 4 & 3.28 & 122 \\
\hline & $\mathrm{AH}$ & 0 & 0 & 0 & 0 & 0 & 0 & 0 & 0 & 0 \\
\hline \multirow{3}{*}{$\begin{array}{l}\text { Contemp. } \\
\text { photo }\end{array}$} & $\mathrm{AO}$ & 0 & 0 & 0 & 0 & 2 & 100 & 0 & 0 & 2 \\
\hline & AA & 0 & 0 & 0 & 0 & 0 & 0 & 0 & 0 & 0 \\
\hline & $\mathrm{AH}$ & 0 & 0 & 0 & 0 & 0 & 0 & 0 & 0 & 0 \\
\hline \multirow[t]{3}{*}{ Artwork } & $\mathrm{AO}$ & 1 & 7.69 & 2 & 15.38 & 10 & 76.92 & 0 & 0 & 13 \\
\hline & AA & 4 & 21.05 & 6 & 31.58 & 7 & 36.84 & 2 & 10.53 & 19 \\
\hline & $\mathrm{AH}$ & 0 & 0 & 0 & 0 & 0 & 0 & 0 & 0 & 0 \\
\hline \multirow{3}{*}{$\begin{array}{l}\text { Political } \\
\text { cartoon }\end{array}$} & $\mathrm{AO}$ & 0 & 0 & 2 & 12.5 & 14 & 87.5 & 0 & 0 & 16 \\
\hline & AA & 11 & 26.19 & 9 & 21.43 & 21 & 50 & 1 & 2.38 & 42 \\
\hline & $\mathrm{AH}$ & 0 & 0 & 0 & 0 & 0 & 0 & 0 & 0 & 0 \\
\hline \multirow{3}{*}{$\begin{array}{l}\text { Original } \\
\text { photograph }\end{array}$} & $\mathrm{AO}$ & 4 & 28.57 & 3 & 21.43 & 7 & 50 & 0 & 0 & 14 \\
\hline & AA & 3 & 42.86 & 0 & 0 & 4 & 57.14 & 0 & 0 & 7 \\
\hline & $\mathrm{AH}$ & 0 & 0 & 0 & 0 & 0 & 0 & 0 & 0 & 0 \\
\hline \multirow{3}{*}{$\begin{array}{l}\text { Images of } \\
\text { artifacts }\end{array}$} & $\mathrm{AO}$ & 0 & 0 & 0 & 0 & 1 & 100 & 0 & 0 & 1 \\
\hline & AA & 0 & 0 & 0 & 0 & 2 & 100 & 0 & 0 & 2 \\
\hline & $\mathrm{AH}$ & 0 & 0 & 0 & 0 & 0 & 0 & 0 & 0 & 0 \\
\hline Historic & $\mathrm{AO}$ & 0 & 0 & 0 & 0 & 0 & 0 & 1 & 100 & 1 \\
\hline \multirow[t]{2}{*}{ maps } & AA & 0 & 0 & 0 & 0 & 0 & 0 & 0 & 0 & 0 \\
\hline & $\mathrm{AH}$ & 0 & 0 & 0 & 0 & 0 & 0 & 0 & 0 & 0 \\
\hline Total & & 86 & 32.70 & 50 & 19.01 & 119 & 45.25 & 8 & 3.04 & 263 \\
\hline
\end{tabular}

As Table 5 indicates, of the 263 corresponding questions asked, the most common classification was level 3, analytical-type questions (45.25\%). Level 1, who-type questions, was the second most common category (32.70\%). The third most common classification was level 2, classifying-type questions, (19.01\%), followed by level 4, new synthesis-type questions, with the fewest corresponding questions, only one question asked, (3.04\%).

The complete lack of corresponding questions in A History of the United States means that the 263 questions asked were dispersed between the two remaining textbooks. Regarding the corresponding questions found in American Odyssey, the written document questions were spilt between level $1(45.83 \%)$ and level $3(54.17 \%)$. Sources such as contemporary photographs of ancient/historic sites, images of artifacts, and historic maps lacked a robust selection of corresponding questions, thereby contributing to the lack of 
disbursement between the DOK classifications. This will be discussed further in chapter 5 . The other primary sources' corresponding questions varied.

\section{Library of Congress Guidelines}

Table 6 shows the raw data and percentages for the primary sources' corresponding questions' Library of Congress guideline classifications. All three textbook's data are presented in this table. 
Table 6. Raw Data and Percentages for the Primary Sources' Corresponding Questions' Library of Congress Level of Analysis by Textbook

\begin{tabular}{|c|c|c|c|c|c|c|c|c|c|c|}
\hline & & Scan & $\begin{array}{l}\text { Scan } \\
\%\end{array}$ & Examine & $\begin{array}{l}\text { Examine } \\
\%\end{array}$ & Analyze & $\begin{array}{l}\text { Analyze } \\
\%\end{array}$ & Compare & $\begin{array}{l}\text { Compare } \\
\%\end{array}$ & Total \\
\hline \multirow[t]{3}{*}{ Written docs } & $\mathrm{AO}$ & 0 & 0 & 13 & 54.17 & 11 & 45.83 & 0 & 0 & 24 \\
\hline & AA & 0 & 0 & 60 & 49.18 & 58 & 47.54 & 4 & 3.28 & 122 \\
\hline & $\mathrm{AH}$ & 0 & 0 & 0 & 0 & 0 & 0 & 0 & 0 & 0 \\
\hline Contemp. & $\mathrm{AO}$ & 0 & 0 & 0 & 0 & 2 & 100 & 0 & 0 & 2 \\
\hline \multirow[t]{2}{*}{ photo } & AA & 0 & 0 & 0 & 0 & 0 & 0 & 0 & 0 & 0 \\
\hline & $\mathrm{AH}$ & 0 & 0 & 0 & 0 & 0 & 0 & 0 & 0 & 0 \\
\hline \multirow[t]{3}{*}{ Artwork } & $\mathrm{AO}$ & 0 & 0 & 5 & 38.46 & 8 & 61.54 & 0 & 0 & 13 \\
\hline & AA & 0 & 0 & 9 & 47.37 & 10 & 52.63 & 0 & 0 & 19 \\
\hline & $\mathrm{AH}$ & 0 & 0 & 0 & 0 & 0 & 0 & 0 & 0 & 0 \\
\hline \multirow{3}{*}{$\begin{array}{l}\text { Political } \\
\text { cartoon }\end{array}$} & $\mathrm{AO}$ & 0 & 0 & 10 & 62.5 & 6 & 37.5 & 0 & 0 & 16 \\
\hline & AA & 1 & 2.38 & 21 & 50.00 & 20 & 47.62 & 0 & 0 & 42 \\
\hline & $\mathrm{AH}$ & 0 & 0 & 0 & 0 & 0 & 0 & 0 & 0 & 0 \\
\hline \multirow{3}{*}{$\begin{array}{l}\text { Original } \\
\text { photographs }\end{array}$} & $\mathrm{AO}$ & 0 & 0 & 9 & 64.29 & 5 & 35.71 & 0 & 0 & 14 \\
\hline & $\mathrm{AA}$ & 0 & 0 & 3 & 42.86 & 4 & 57.14 & 0 & 0 & 7 \\
\hline & $\mathrm{AH}$ & 0 & 0 & 0 & 0 & 0 & 0 & 0 & 0 & 0 \\
\hline \multirow{3}{*}{$\begin{array}{l}\text { Images of } \\
\text { artifacts }\end{array}$} & $\mathrm{AO}$ & 0 & 0 & 1 & 100 & 0 & 0 & 0 & 0 & 1 \\
\hline & AA & 0 & 0 & 2 & 100 & 0 & 0 & 0 & 0 & 2 \\
\hline & $\mathrm{AH}$ & 0 & 0 & 0 & 0 & 0 & 0 & 0 & 0 & 0 \\
\hline Historic & $\mathrm{AO}$ & 0 & 0 & 0 & 0 & 0 & 0 & 1 & 100 & 1 \\
\hline \multirow[t]{2}{*}{ Maps } & $\mathrm{AA}$ & 0 & 0 & 0 & 0 & 0 & 0 & 0 & 0 & 0 \\
\hline & $\mathrm{AH}$ & 0 & 0 & 0 & 0 & 0 & 0 & 0 & 0 & 0 \\
\hline Total & & 1 & 0.38 & 133 & 50.57 & 124 & 47.15 & 5 & 1.90 & 263 \\
\hline
\end{tabular}


As Table 6 shows, a vast majority of the corresponding questions were classified as examine questions $(50.57 \%)$ followed closely by those classified as analyze questions (47.15\%). Only 1 question was classified as scan $(0.38 \%)$, and 5 as compare (1.90\%). Excluding $A$ History of the United States due to its lack of corresponding questions, both remaining textbooks demonstrated similar classifications for most of their primary source classifications. The exceptions to this trend were American Anthem's historical maps and contemporary photos, which lacked any corresponding questions and this textbook's 1 political cartoon classified as a scan question and the 4 written documents classified as analyze. American Odyssey's 1 historic map classified as analyze also deviated from the general trend.

Answer in text

Table 7 presents the raw data and percentages for the corresponding questions with answers in the text. The data for each type of primary source and from each textbook is listed in the table. 
Table 7. Raw Data and Percentages for the Corresponding Questions With Answers in Text by Textbook

\begin{tabular}{lllllll}
\hline & & Yes & Yes \% & No & No \% & Total \\
\hline Written docs & AO & 8 & 33.33 & 16 & 66.67 & 24 \\
& AA & 21 & 17.21 & 101 & 82.79 & 122 \\
Contemp. Photo & AH & 0 & 0 & 0 & 0 & 0 \\
& AO & 2 & 100 & 0 & 0 & 2 \\
& AA & 0 & 0 & 0 & 0 & 0 \\
Artwork & AH & 0 & 0 & 0 & 0 & 0 \\
& AO & 0 & 0 & 13 & 100 & 13 \\
\multirow{5}{*}{ Political cartoon } & AA & 8 & 42.11 & 11 & 57.89 & 19 \\
& AH & 0 & 0 & 0 & 0 & 0 \\
Original photographs & AO & 0 & 0 & 16 & 100 & 16 \\
& AA & 18 & 42.86 & 24 & 57.14 & 42 \\
Images of artifacts & AO & 0 & 0 & 0 & 0 & 0 \\
& AA & 4 & 28.57 & 10 & 71.43 & 14 \\
& AH & 3 & 42.86 & 4 & 57.14 & 7 \\
Historic maps & AO & 0 & 0 & 0 & 0 & 0 \\
& AH & 0 & 0 & 1 & 100 & 1 \\
Total & AO & 2 & 100 & 0 & 0 & 2 \\
& AA & 0 & 0 & 0 & 0 & 0 \\
& AH & 0 & 0 & 1 & 100 & 1 \\
& & 0 & 0 & 0 & 0 & 0 \\
& & 0 & 0 & 0 & 0 & 0 \\
& & 66 & 25.10 & 197 & 74.90 & 263 \\
\hline
\end{tabular}

Of the 263 corresponding questions, 197 (74.90\%), or nearly three quarter of the questions, did not have answers located within the text. Only 66 (25.10\%) had answers found within the text. A History of the United States had no corresponding questions for any of its primary sources; therefore it will not be discussed any further in this section. American Odyssey's corresponding questions for the images of artifacts were the only questions to have all their answers found within the text. Every other type of primary source, regardless if they belonged to American Odyssey or American Anthem, had a majority of corresponding questions without answers found in the text.

\section{Page filler}

Table 8 presents the raw data and percentages of primary sources that were classified as page filler due to their lack of corresponding questions. The data from each textbook is presented in this table. 
Table 8. Raw Data and Percentages of Page Filler Primary Sources by Textbook

\begin{tabular}{|c|c|c|c|c|}
\hline & & Page Filler & Page Filler $\%$ & $\begin{array}{l}\text { Total Primary } \\
\text { Sources }\end{array}$ \\
\hline Written & $\mathrm{AO}$ & 225 & 90.4 & 249 \\
\hline \multirow{2}{*}{ docs } & AA & 182 & 60 & 304 \\
\hline & $\mathrm{AH}$ & 78 & 100 & 78 \\
\hline Contemp. & $\mathrm{AO}$ & 0 & 0 & 2 \\
\hline \multirow{2}{*}{ Photo } & AA & 0 & 0 & 0 \\
\hline & $\mathrm{AH}$ & 5 & 100 & 5 \\
\hline \multirow[t]{3}{*}{ Artwork } & $\mathrm{AO}$ & 114 & 89.76 & 127 \\
\hline & AA & 24 & 55.81 & 43 \\
\hline & $\mathrm{AH}$ & 183 & 100 & 183 \\
\hline Political & $\mathrm{AO}$ & 19 & 54.28 & 35 \\
\hline \multirow[t]{2}{*}{ cartoon } & AA & 5 & 10.64 & 47 \\
\hline & $\mathrm{AH}$ & 31 & 100 & 31 \\
\hline Original & $\mathrm{AO}$ & 383 & 96.47 & 397 \\
\hline \multirow[t]{2}{*}{ photographs } & AA & 7 & 50 & 14 \\
\hline & $\mathrm{AH}$ & 270 & 100 & 270 \\
\hline \multirow{3}{*}{$\begin{array}{l}\text { Images of } \\
\text { artifacts }\end{array}$} & $\mathrm{AO}$ & 35 & 97.22 & 36 \\
\hline & AA & 5 & 71.43 & 7 \\
\hline & $\mathrm{AH}$ & 25 & 100 & 25 \\
\hline & $\mathrm{AO}$ & 0 & 0 & 1 \\
\hline \multirow{2}{*}{ maps } & AA & 0 & 0 & 0 \\
\hline & $\mathrm{AH}$ & 6 & 100 & 6 \\
\hline Total & & 1597 & 85.86 & 1860 \\
\hline
\end{tabular}

Of the 1860 primary sources, 1597 (85.86\%) of the sources lacked any corresponding questions. This overwhelming majority was labeled as page filler as there were no questions to prompt the students to analyze or otherwise interact with the primary source.

Interestingly, a majority of every primary source type, with the exception of historical maps and contemporary photos, were classified as page filler in each textbook. Of those two exceptions, American Odyssey's 1 historical map and its 2 contemporary photos were accompanied by corresponding questions, resulting in the above percentages.

\section{Concluding statements}

Each of the textbooks shared many similarities - their publication by big corporations and the involvement of their respective board members with other corporations and organizations, the general structure and organization of the textbooks, and the direct involvement of well-educated authors and contributors. Most importantly for this study, was the lack of corresponding questions for the majority of the primary sources included in the 
three textbooks. The authors of A History of the United States chose not to include any corresponding questions with the primary sources, while American Odyssey included some corresponding questions of varied levels of analysis, but mostly they were classified as one of the two middle range categories of analysis on the LOC (examine and analyze) and the first the third categories on the DOK. American Anthem provided the most corresponding questions of the three textbooks with a majority of the questions classified as either examine or analyze on the LOC and across all levels on the DOK. Additionally, a majority of the corresponding questions from both textbooks did not have answers found within the text. While some questions were asked about the primary documents, a vast majority of the primary sources were left without. From the examination of the raw data, it appears that some textbooks view primary sources in different ways. The possible reasons for these variances will be discussed in chapter 5 .

This study's reported results will be discussed at length in the following chapter. The discussion will be framed from the perspectives of both historians and social studies researchers. Following these framed discussions will be a conversation about the additional implications and limitations of this study, as well as suggestions for further research. 


\section{Chapter 5: Discussion}

\section{Introduction}

The previous chapter presented the results from the study's data collection process. This chapter will interpret and discuss the data from the perspectives of both historians and social studies researchers. The frameworks from which these two groups operate are different and must be explained. This chapter will first start with a review of the study, and then proceed to an explanation of the frameworks and then proceed to the discussion of the results. Following these discussions, this chapter will address the study's unexpected findings, limitations, suggestions for future research, and recommendations to publishers, historians, social studies researchers, and social studies educators.

\section{Review of the study}

Textbooks, the most commonly used historical instructional resource, continue to dominate public school instructional time (Banks, 1969; NCSS, 1988; Patrick \& Hawke, 1982; Ravitch \& Finn, 1987; Tyson \& Woodward, 1989; Wade, 1993). The textbook companies tell us they continually modify the content and corresponding activities included in these textbooks in order to try to meet the changing needs of the targeted audiences. Sometimes, the textbooks truly meet the specific needs of the audience and other times the textbooks fail to meet those expectations. Determining whether the evaluator believes that the textbook meets the audience's needs first requires an understanding of the framework within which the evaluator operates and the specific areas of concern the evaluator wishes to examine.

This study chose to systematically examine one specific area of concern, the ways in which the textbooks utilized primary sources. The primary sources were first classified into 7 types:

- written documents

- original photographs

- photographs of ancient/historic sites

- political cartoons

- images of artifacts

- original artwork

- historic maps 
Then the criteria for evaluating the primary sources' corresponding questions were developed by incorporating the Library of Congress' primary source evaluation criteria and by modifying the Depth of Knowledge criteria to fit the needs of the study. This completed evaluation instrument was used to gather the data for this study. The subsequent data analysis illustrated that the three textbooks utilized primary sources in differing ways, but none of the textbooks utilized primary sources in ways that adequately meet the needs of historians or the various perspectives within the social studies.

Germane to this study, were the ways in which the three textbooks asked, or failed to ask, students to analyze the various types of primary sources. Historians and social studies researchers alike denoted the importance of analyzing primary sources (Banks, 1984; Barton, 2008; Cuban, 1993; Davies, Lynch, \& Davies, 2003; Levstik, 2008;Musbach, 2001; Paxton, 1999), and both of their perspectives on this study's results warranted examination. The overarching ideological wars regarding education are highlighted as contributors to the role of learning how to use primary documents.

\section{Historians' Frame}

For historians, the analysis of primary sources is the backbone of their profession. Any worthwhile historical research interprets primary sources in conjunction with the examination of existing secondary sources. A cursory examination of several reputable history programs as well as reputable websites such as The Library of Congress tries to illuminate the novice about the field and of the essential use of primary sources and their subsequent interpretations (Library of Congress, 2002; Stanford University History Department, 2009; University of Princeton History Department, 2009).

Historians analyze primary sources in several ways, each of which are reflected in the Library of Congress' primary source evaluation criteria used in this study's data gathering instrument. Logically, if historians utilize such evaluation criteria, they would also advocate or expect that students studying history should also approach the subject incorporating a healthy examination of primary sources. Not only is evaluating primary sources an important skill students should master, but it is also the preferred method of understanding the nature of history (Levstik \& Barton, 2005; Wineburg, 1991; Dickinson \& Lee, 1978). Most history educators agree that history courses should not take the form of dictation and recitation of a story. Instead, students should interact with a wide variety of 
primary sources from various perspectives in conjunction with a general recollection of the past (Levstik \& Barton, 2004). Additionally, students should also be encouraged to recognize the author's bias when examining both primary and secondary sources. Several researchers examine the learning of history. Specifically, on if and how students, even elementary students, can critically examine primary sources and what they learn from that process (Wineburg, 2001).

So, when evaluating a textbook, the historian expects to find the inclusion of a wide variety of primary sources that hopefully represent several perspectives. The historian would examine the ways in which the textbook asks the student to analyze these sources. Ideally, the textbook acts as a teaching tool and would provide the student with opportunities and prompts or scaffolding to analyze the primary sources on a variety of levels. Thereby aiding through guided practice the skills utilized regularly by historians. Ultimately, the historians would want to know: How does the textbook encourage the students to interpret and analyze the information as a means of understanding the past?

\section{Social Studies Researchers' Frames}

Social studies researchers also promote critical inquiry within the history classroom (Engle \& Ochoa, 1988; Hahn, 1998; Hartoonian, 2002; Parker, 2002; Patrick, Vontz, \& Nixon, 2002). The purpose, unlike the historians, includes but also extends beyond critically interpreting the information to gain a better understanding of the past. The field of social studies approaches history from several different angles. One of the primary concerns is certainly developing an understanding of the ways in which one organizes and explains past events (Hicks \& Doolittle, 2008; Levstik \& Barton, 2004). But additionally, social studies researchers concern themselves with the actual development of the critical analysis skill set. Levstik and Barton label this as developing an analytic stance toward history.

Beyond the acquisition of the understanding of the past and the development of critical analysis skill sets, there are those in the field of social studies who recognize the importance of promoting democratic education through the examination of controversial issues (Camicia, 2008; Engle, 1960; Hess, 2008; Ochoa-Becker, 2007). As history courses are the most frequent social studies courses offered, it falls on the history curriculum to promote democratic education through examining present and past controversial issues Hess; Engle \& Ochoa, 1988). The question most frequently asked in the past concerning 
textbooks was, "How well do the history textbooks present and position various groups and/or specific individuals within the described power relations and ideological positions (Camicia; Pinar, Reynolds, Slatter, \& Taubman, 1995)?

There are many perspectives within the field of social studies, each stressing various specific disciplines. The inclusion of content foci within the 10 NCSS standards illustrates the importance of the various social science and related disciplines that comprise social studies. So, in addition to the promotion of democratic education, other social studies researchers would hope to see the authentic examination of economics, anthropology and sociology, geography, and several other disciplines and their respective types of primary data presented within the textbooks (Merryfield, 2008; Baker \& Bednarz, 2003; Hartoonian, 2002). Although many social studies researchers might focus more on one or more of the social sciences contributing to social studies content, these individuals would also hope to find evidence that history is more than a well-told story, but one in which critical examination of related information is an integral part of the learning process.

This study only examined the inclusion and treatment of primary sources and the types of corresponding questions asked. Most times, only one primary source on a topic was presented in the textbook to serve as a descriptive example rather than presenting several sources that would allow for a greater sense of depth though an examination of multiple perspectives and a higher degree of debate. Also lacking from each textbook were the tables and graphic representations of statistics from the observed time periods. The absence of the primary sources associated with social science perspectives such as economics limited the types of analysis available to students. The absence may also have implied that textbook publishers limit the classification of primary sources to that of words and selected types of illustrations, ignoring the contributions to the depth of understanding that additional social science perspectives might have added.

\section{Ideological Dissonance}

Examining the frames of the historians and the social studies researchers, it becomes apparent that one must extend the discussion to an overarching ideological dissonance. At the heart of the culture wars in social studies is the debate on the definition of social studies (Evans, 2004). Should the field of social studies remain primarily defined as history education or should the field be redefined as a more broad discipline that 
focuses on critical thinking and social issues (Ravitch, 2000; Ross, 2000)? The answer to this question has yet to be resolved. In fact, as the literature review indicates, the debate remains quite heated due to the political nature of the question.

Much like the political issues surrounding Harold Rugg, the current nature of social studies remains highly political. Special interest groups fight the progressive direction of the field, attacking the ideas of the social justice movements as well as the emphasis on critical pedagogy and even social activism in favor of maintaining the status quo (Dahlgren \& Masyada, 2009). Additionally, the opposing sides of the culture war present contrasting viewpoints on the actual story currently being told or the story they wish to see in the history textbook. The more conservative group advocates for a more "patriotic" version of American history where the injustices placed upon certain peoples are downplayed if not ignored to present our nation in a more positive light (Finn, 1991; Ravitch, 2003). The more liberal groups on the other hand advocate for a story focusing on social change and the examination of class, race, and gender. The opposing parties constantly debate these issues resulting in leaving the textbooks with the compromise choice to include mere cursory references to the racial, social, and gender groups. Until this issue is resolved, the nature of the textbooks, their content, and purposes will remain a hotly contested issue, and the product will likely not appease either side.

\section{Discussion of Results}

\section{General Discussion}

While textbooks, regardless of their format, remain a vital element of the history curriculum, textbook analysis should also maintain a vital presence through a body of research (Lewin, 2009). Primary source evaluation remains paramount to both historians and social studies researchers. Since both groups promote the inclusion of primary sources, research should monitor this important curricular element. Even if textbooks transition completely to the digital format, primary resources will be present and perhaps to an even greater degree than in the traditional book format. Digital books may even be able to better provide or tap collections of related primary sources. Future studies should examine the ways in which digital textbooks treat primary sources and compare the results to that of the treatment by traditional textbooks. Several states, including California, have already announced their intention to transition completely to digital textbooks. This is a new 
pressure for the textbook company, the implications of which should be considered by future studies. Will textbook companies even be able to change the traditional textbooks due to cost restrictions, especially when facing the need to transition to the digital format? This is also another consideration future studies should consider.

It can be noted though, that regarding the attempt to use primary sources for the development of critical inquiry skill sets and historical thinking skills, the success of the three textbooks sampled varied. In assessing the textbook alone, American Anthem presented not only a variety of primary sources, but also a variety in the types of questions asked. American Odyssey presented a variety of primary sources, but had a limited number of corresponding questions. A History of The United States lacked any corresponding questions for its primary documents and would require that a teacher provide supplemental materials to develop this skill set and to assist students in approaching American history in keeping with the skills of an historian. Perhaps these materials supplemented the textbook with additional primary sources and a greater number of corresponding questions. For this reason, future studies should research the supplemental learning resources.

This study attempted to evaluate the treatment of primary sources by the three selected textbooks from the perspectives of historians and the various perspectives within the social studies. While fully capable of examining the data from the perspective of the historian, this study can only present cursory indications of how the different social studies perspectives would view the data and how these disciplines were represented in the primary sources found in history books. Small additions to the instrument might incorporate systematic ways to record this additional information.

Historians would be pleased to note that two of the three textbooks provide some corresponding questions for the primary sources. They likely would be displeased, however to note the limited variety of primary sources as well as the limited presence and variety of the corresponding questions. Primary sources were much more likely used to illustrate "points in the story of the United States" rather than presenting multiple perspectives on issues in the subject matter. This is a finding that social studies researchers would also find troubling. Some of the general areas other social studies researchers might find displeasing include the major deficit regarding historical maps and the subsequent lack of critical evaluation type questions focusing on more of their elements rather than the location 
depicted. Economists would also be displeased at the lack of original data regarding financial matters as they pertain to U.S. history. Sociological researchers, however, would be pleased at the inclusion of so many original photographs and artwork as their examination can aid in the understanding of society and its structure during a given period of time. Additional research has the potential for a greater examination of textbooks concerning the perspectives and skills associated with these various social sciences.

The three textbooks treated primary sources in very different ways. The location of corresponding questions associated with a primary source, illustrated the one commonality among the three textbooks - most primary sources lacked corresponding questions. The fact that $85.81 \%$ of the primary sources included within the textbooks lacked any corresponding questions suggested that the textbook authors and editors did not believe textbooks should make primary source evaluation an important goal of the textbook. Given the delicate nature of trying to balance the incredible demands exerted upon the textbook by various groups and organizations for specific content inclusion, perhaps this lack of priority was understandable. Nonetheless, the examined textbooks used the overwhelming majority of primary sources as page filler resources. The mere appearance of a replica of the Constitution within the pages of the textbook was an inadequate method of teaching its content and its importance. Historian and social studies researcher would both undoubtedly view the frequency of using primary documents as page fillers with concern and for the missed opportunities to learn critical thinking skills.

\section{Types of Primary Sources}

Written documents (631) and original photographs (681) were the two most commonly occurring primary sources. The least common primary sources were historic maps (7) and contemporary photographs of historic/ancient sites (7). Regarding the specific textbooks, American Odyssey incorporated original photographs (397) and written documents (249) at a higher rate than any other type of primary source. However positive this larger number, it still remained that of its written documents, $90.4 \%$ were classified as page filler and $96.47 \%$ of the original photographs were also classified as page filler. American Anthem's most commonly occurring primary source was written documents (304) and while lower than American Odyssey, the study still revealed 60\% of the documents classified as page filler. The entirety (100\%) of the text A History of The United States' 
primary sources was classified as page filler. Its total lack of corresponding questions was initially surprising as both authors were noted historians. Of the three textbooks, A History of the United States most closely resembled a collegiate-level history textbook, and college textbooks tend to lack skill development exercises. Only one textbook, American Anthem, provided its readers with primary documents that were not used as page filler. Of the 47 occurrences of political cartoons, 42 were accompanied by corresponding questions. American Odyssey included 16 political cartoons (45.72\%) that were accompanied by corresponding questions.

Overall this finding suggested that written documents and photographs tended to lend themselves to incorporation into a textbook, without a required thought or analysis. However, political cartoons with their required interpretations of symbols appeared to lend themselves more readily open to requiring questions. There might have been something about the obvious nature of cartoons that simulated the presence of accompanying questions. That, however, does not mean that written documents and photographs are automatically meaningful and might not be more so if and when questions are raised about these resources. However, given the massive number of curriculum standards and the length of the textbooks used in most social studies courses, it may be that teachers and students would benefit from the stimulation of the presence of questions and be less likely to skip over these pictures and documents when using the textbook.

Historians and social studies researchers both advocate the inclusion of a wide variety of primary sources. These textbooks rely heavily on written documents and photographs thereby excluding a wide swath of primary sources such as original data sets and historical maps. This lack of diversity limits the ways in which students can interpret the past and provide a narrow perspective on past events. Both historians and social studies professionals would be disappointed at the lack of inclusion of multiple perspectives. These findings raise broader questions including: To what extent are the textbook companies limited in their primary source choices due to copyright issues? Where should researchers draw the line regarding textbook expectations? Are the expectations for each grade level grounded in research? Does the reality of the textbooks' curriculum in history as a whole enable students to meet expectations?

\section{Location of Corresponding Questions}


The location of the few corresponding questions revealed that 224 or $12.04 \%$ were located directly under the primary source. The other common locations were: on the page prior or following the document (33 or 1.78\%), and elsewhere on the same page (6 or $0.32 \%$ ). The immediacy of these locations suggested a user-friendly approach toward analysis. The reader was not required to flip through the book in order to answer the question and analyze the source. The questions were in close approximation to the primary source.

\section{Depth of Knowledge (DOK)}

The types of questions asked were primarily split between the level 3 (45.25\%) and (32.70\%) level 1. Excluding A History of The United States, the remaining two textbooks followed this general trend, although American Anthem provided a relatively more inclusive disbursement of the corresponding questions across the four DOK levels than did American Odyssey. The three textbooks' lack of corresponding questions for primary sources such as historical maps, images of artifacts, and contemporary photos of ancient/historic sites missed the opportunity to focus on the four DOK categories. The lack of corresponding questions raised some additional questions regarding the intentions of the textbook authors and editors. Was the lack of corresponding questions intentional? What does this lack of inclusion say about the authors and editors opinions regarding the role and importance of these three sources? What does it say about their assumptions concerning the skills and beliefs of the teachers who use their textbooks?

\section{Answers in Text}

This study also recorded the occurrence of answers to the corresponding questions found within the actual narrative of the text. The fewer the answers found within the text, means that students must find the answers themselves. Critical analysis is not likely to occur when the answers to the questions are found within the text. The two textbooks', American Odyssey and American Anthem, primary sources' corresponding questions overwhelmingly posed questions that lacked specific answers within the text. This ensured that students relied on their own critical analysis skill sets to answer the questions. Of the questions asked about specific primary sources, only the 2 contemporary photographs of ancient/historic sites and the 3 images of artifacts had a majority of their questions answered in the text. The fact that most of the corresponding questions did not have answers found in the narrative 
text also suggested that the two textbooks were more aligned with the historical inquiry and critical analysis skill set development goals. However, no instructional statement indicating how the teachers and students should approach the primary documents was provided in the textbooks.

\section{Limitations of the study}

As an initial study of primary documents in textbooks the study collected information on the types of primary documents and the locations and types of questions that accompanied the primary documents. This study limited itself to an examination of three of the most widely adopted U.S. History textbooks, and excluded consideration of any Advanced Placement textbooks. Additionally, the teacher's editions and supplemental materials were excluded from this study. The study focused only on the resources and resourcefulness of the student's textbook because of its great use in the social studies classrooms.

\section{Future research}

Examining the teacher's textbooks and supplemental materials should be a next step in future studies, as doing so would certainly provide a richer description of the ways in which textbook packages promote the utilization of primary sources. Teacher guides and supplemental materials may include greater guidance for the use of primary sources. However, there is no guarantee that teachers would use these and so another future research project should address how teachers use primary sources when they teach classes.

Future studies should also examine the ways in which Advanced Placement textbooks utilize primary sources and extend beyond that to compare the results with that of the general textbooks. Advanced Placement textbooks include a strong presence of Document Based Questions (DBQ). Oftentimes, the documents used are primary sources and the types of questions asked are critical in nature. Therefore, it would be logical to assume that an Advanced Placement teacher might conduct this course in a different manner than a teacher of a regular history course. Textbooks for middle school grades also need to be examined to see if students in these grades are introduced to and taught to use primary documents in any systematic way.

This study described the various types of primary sources and the presence of data analysis assistance through corresponding questions. It did not seek to learn if the primary 
sources were related to a particular perspective/viewpoint/or interpretation of history. Future iterations of this study might include an expanded instrument that incorporates a qualitative section that adequately addresses the ways in which the primary sources promote the examination of controversial issues and content related to the inclusion of issues of particular concern social scientists.

This research only began the examination of a body of research related to the use of primary documents, but it opened a plethora of additional questions for philosophical, quantitative, and qualitative research. For instance, does the lack of corresponding questions severely prohibit the discussion of other more important curricular questions? Do supporting textbook materials make an effort to concentrate on the best use of the primary sources available in the textbook? What should be the role of the textbook? Was the lack of corresponding questions intentional? What does this lack of inclusion say about the authors and editors opinions regarding the role and importance of these three sources? Where should researchers draw the line regarding textbook expectations? Are the expectations for each grade level grounded in research? Does the reality of the textbooks' curriculum in history as a whole enable students to meet expectations? Further research should examine these questions.

\section{Implications}

The reluctance of textbook evaluators to share their instruments with the larger research community greatly stagnated textbook analysis research. No research had been conducted regarding questions related to primary documents and subsequently; no instrument existed with which one could examine textbooks' treatment of primary sources. This study sought to focus on two goals, the first of which was to provide an instrument that would begin to address the important topic of primary source analysis in a systematic and transparent manner.

Additionally, this study sought to provide transparency about the instrument's development and the outcome, as well as the raw data's use revealed. This instrument worked to systematically gather comparative data. Several changes to the instrument might be made as a result of the findings. Firstly, since the DOK and the LOC effectively evaluated the corresponding questions in similar ways, one of the criteria might be eliminated. Secondly, the sections of the second category that examined the representation 
of ethnic, gender, political, and religious groups and their key historical figures might be eliminated and instead a completely new instrument that more adequately examines the quality of representation would be more helpful, especially to those social studies educators who have interests in particular social science disciplines. Since this study marks only the beginning of a body of research related to the teaching of primary data, it used and focused on general high school textbooks. Future studies should examine the middle school level textbooks. Studies should also examine the ways in which teachers use the textbooks in the classroom to analyze primary sources and the skill sets necessary for teachers to adequately teach these skill sets.

The second goal sought to provide educators with additional knowledge regarding several of the most widely adopted high school textbooks and their treatment of primary sources. For educators, it is important to understand what the textbook provides for students to be able to best utilize the textbook. The examined textbooks found variation in the their treatment of primary resources, and it is important that educators too realize these differences exist as these differences will demand that teachers adjust their instruction and planning accordingly to meet curriculum goals.

As the facilitator of the educational experience, teachers play a major role in guiding students on how to use and analyze the primary sources. This also implies the importance of an examination of the teacher's guides and the supplemental materials to see what, if any, guidance is provided for the teachers. Judging just the textbooks alone, if a teacher lacks his/her own skill sets to supplement the textbook with primary source evaluation questions and activities, then perhaps he/she should select a textbook that provides students with more prompting questions or with a skills section that includes how to examine primary documents.

On the basis of evaluating the textbooks alone, I suggest that textbook publishers might want to modify their presentation of primary sources by including a greater presence and variety of guiding questions for all types of primary sources, not just written documents and photographs. This increase in questions would most probably aide in the development of critical evaluation skills as well as increasing the opportunity to examine controversial issues. Additionally, methods instructors need to become aware of the need to include 
greater emphasis on instruction in the teaching of the use of primary sources, especially given their important role to history and its role in the social studies curriculum.

\section{Recommendations}

In addition to the expanding research on the treatment of primary documents in textbooks and other instructional resources, further recommendations on how textbooks could better use primary sources is necessary. From the perspectives of both historians and social studies researchers, the textbooks should extend beyond presenting a well-told story to include multiple perspectives and a wide variety of sources that help students analyze the events of the past. This means including not just a wider variety of primary sources but also primary sources that are representative of multiple perspectives on a single topic would focus more on the nature of the historians work. Professors of history may also want to provide more examples and or instruction in their own use of primary documents as important contributors to their craft and interpretation of the past.

The practitioners of various social science perspectives would also have suggestions. Geographers would likely suggest a greater inclusion of original maps as a means of not only better understanding the past, but to also understand the progression of map making as well as the development of map analysis skills. Economists would most likely suggest increasing the presence of original statistics to not only help students better understand the past but to also gain a greater understanding of economic principles and trends. Even though the multicultural movement brought about a greater inclusion of a wider range of groups of people in the textbooks, sociologists and anthropologists might also want to assure that primary sources reflect the perspectives of different groups of people. Each social science

perspective would most likely wish to see a greater inclusion of primary sources that help to address their specific concerns in addition to understanding history. In order to ensure their voices are heard, perhaps each of the social science organizations might draft formal suggestions and statements to guide the textbook companies regarding adjustments to primary sources.

Textbooks companies should also require their authors and editors to include an official declaration on why and in what ways they are using primary sources. The lack of disclosure on this issue leaves the potential users in a position of making assumptions about the intended use of the purposes resources included in their texts. Even if the authors or 
editors believe treating the primary resources as page fillers is an appropriate course of action, there should be an effort to help and encourage the student to at least look at the source and give it some form of consideration. Researchers aside, teachers and students who use the book are entitled to know the perspective the author takes on the use of primary documents.

\section{Concluding Statements}

Researchers should constantly evaluate the predominant materials utilized in the classroom seeking to learn if these materials adequately assist teachers in the process of educating students. Asking, "How can teachers best approach the use of the available materials?" is a key question for curriculum development. In the case of primary sources, this research found that the three textbooks varied widely in the ways in which they treated primary sources and teachers should be aware of these differences when selecting textbooks. This is especially important in locations where money for additional resources is in short supply.

Textbook publishers can also benefit from this study. The inclusion of a wide variety of primary sources from multiple perspectives along with their corresponding questions can enhance the textbook on several levels. Firstly, textbooks can present more than just a welltold story. They can present multiple perspectives regarding historical events in a fashion that not only assists the students in better understanding the past but will also help develop critical analysis skill sets. These are concerns that educators recommend and wish to see addressed and can surely improve the quality of the published textbooks. The evaluated textbooks failed to use primary resources to present multiple perspectives on past events by using a wide variety of primary sources on single events or issues. Also, while corresponding questions were posed, most primary sources were classified as page filler. The textbook publishers already have a base from which to improve, they just need to expand upon it to make their textbooks even stronger, more functional. More care needs to be taken so that the narrative and the primary documents approach the same learning objectives to enhance the understanding of the content.

In recent days, several large adoption states have indicated withholding the purchase of new textbooks. Should this have an impact on the publisher that slows down the revisions of books then the next generation of teachers will continue to have books 
whose treatment of primary documents remains as reported here. This means that the improvement in focus and teaching of primary documents will be the responsibility of teachers and an ever-increasing number of beginning teachers. This means that methods instructors should in their already very crowded syllabus provide more instruction on the use of primary documents so that the best ways of teaching social studies and history are practiced and learned.

Students can also gain from this study. In fact, students are the most important of the major stakeholders. The examination of primary sources and the development of this skill set remains a vital component of students' educational experience and this study embarks on a line of research that opens the door for qualitative research regarding this category of stakeholder and their experiences evaluating primary sources as presented in textbooks.

The degree to which this research pointed to the absence of statements of purposes by the publishers for their inclusion of primary documents in the history books and of assistance and motivating challenges to students to examine the primary documents was important. Research on how students respond to the primary documents in the texts is needed so also is research on if and how teachers use the primary documents in the textbooks as instructional resources during class periods.

Finally, this study suggests the need for a renewed and increased interest in researching the ways in which textbooks not only treat primary sources but also in the need for increased transparency in textbook evaluation instruments. Improvements in textbook analysis research are necessary to ensure that the suggestions provided to teachers and publishers are grounded in sound research that can be replicated to measure changes over time. When regarding important content issues associated with learning, of which primary source evaluation is only one, researchers need to play an important role in providing consultation based on known data. 


\section{References}

Achilles, C. M. (1977). GALLUPing to the POLLS or Hitching Your Bandwagon to a Slogan. Paper prepared for Secondary School Principals, ETEA.

Ahmad, I., Brodsky, H., Crofts, M.S., \& Ellis, E. G. (2001). World cultures: A global mosaic. Upper Saddle River, NJ: Prentice Hall.

American History Association. (1909). The study of history in elementary schools: the report of the Committee of Eight. New York: Charles Scribner's Sons.

American History Association. (1910). The study of history in secondary schools: the report of the Committee of Five. Annual Report, 1910, 230-231.

American Historical Society. (1899). The study of history in schools. New York: Macmillan.

American Textbook Council. (1994). History textbooks: A standard and guide. New York: American Textbook Council. (2008). Widely adopted history textbooks. New York: American Textbook Council.

Anderson, L. F. (2001). Schooling and citizenship in a global age. Issues in Global Education, 164, 1-19.

Andrew, J.A. (1998). Lyndon Johnson and the Great Society. Chicago, Il: Ivan R. Dee, Publisher.

Apple, M. W. (1986). Teachers and texts: A political economy of class and gender relations in education. New York: Routledge \& Kegan Paul Books.

Ashby, R. (2004). Developing a concept of historical evidence: Students' ideas about testing singular factual claims [Electronic version]. International Journal of 
Historical Learning, Teaching and Research, 4.

Ayers, E. L., Schulzinger, R. D., De La Teja, J. F., White, D. G. (2007). American Anthem. Orlando, FL: Holt McDougal.

Bagley, W. (1931). The textbook and methods of instruction. In G. Whipple (Ed.), The textbook in American education, Thirtieth yearbook of the National Society for the Study of Education, Part 2 (pp. 7-26). Bloomington, IL: Public School Publishing.

Baker, T. R., Bednarz, S. W. (2003). Lessons learned from reviewing research in GIS education. Journal of Geography, 102, 231-233.

Banks, J. (1969). A content analysis of the Black American in textbooks. Social Education, 33, 954-957.

Banks, J. A. (1984). Teaching strategies for ethnic studies. Boston, MA: Allyn \& Bacon.

Banks, J. A., \& Clegg, A.A., Jr. (1973). Teaching strategies for the social studies: Inquiry, valuing, and decision-making. Reading, Massachusetts: Addison-Wesley.

Barr, R. D., Barth, J. L., \& Shermis, S.S. (1977). Defining the social studies, Bulletin No. 51. Washington D.C.: National Council for the Social Studies.

Barton, K. C. (1994). Historical understanding among elementary children. Unpublished doctoral dissertation, University of Kentucky, Lexington. (2008). Research on students' ideas about history. In L. S. Levstik and C.

A. Tyson (Eds.), Handbook of research on social studies education (pp. 239-258). New York: Routledge.

Beck, I.L. \& McKeown, M.G. (1991). Conditions of vocabulary acquisition. In R. Barr, M.L. Kamil, P. Mosenthal, \& P.D. Pearson (Eds.), Handbook of reading research 
(Vol. 2, pp. 789-814). New York: Longman.

Beck, I.L., McKeown, M.G., \& Sinatra, G.M. (1991). Revising social studies text from a text-processing perspective: Evidence of improved comprehensibility. Reading Research Quarterly, 26, 251-276.

Beck, I. L., McKeown, M. G., \& Worthy, J. (1995). Giving a text voice can improve student understanding. Reading Research Quarterly, 30, 220-238.

Bernstein, I. (1996). Guns or butter: the presidency of Lyndon Johnson. Oxford: Oxford University Press.

Binder, A. J. (2002). Contentious curricula: Afrocentrism and creationism in American public schools. Princeton, NJ: University Press.

Boorstin, D. J., \& Kelley, B. M. (1999). A History of the United States. Newark, NJ: Pearson/Prentice Hall.

Burack, J. (2003). The student, the world, and the global education ideology. In J. Leming, L. Ellington, \& K. Porter-Magee (Eds.), Where did social studies go wrong? (pp. 4069). Washington D.C.: The Thomas B. Fordham Foundation.

Bureau of Education. (1916). The social studies in secondary education. Bulletin No. 28. Washington DC: U.S. Government Printing Office. 
California State Board of Education (1988). History-social science framework for California public schools kindergarten through grade twelve. Sacramento: California State Board of Education.

Camicia, S. P. (2008). Deciding what is a controversial issue: A case study of social studies curriculum controversy. Theory \& Research in Social Education, 36, 298-316.

Cannon, L. (1991). President Regan: the role of a lifetime. New York: PublicAffairs.

Carr, E. H. (1961). What is history? New York: Vintage Books.

Cassanello, R. (2006, August). Education reform and the history wars in Florida [Electronic version]. OAH Newsletter, 34, 17.

Clark, R., Allard, J., \& Mahoney, T. (2004). How much of the sky? Women in American high school history textbooks from the 1960's, 1980's, and 1990's. Social Education. 68, 31-48.

Clawson, R. A. (2003). Poor people, black faces: The portrayal of poverty in economics textbooks. Journal of Black Studies, 32, 352-61.

Commager, H. S. (1980). The study and teaching of history. Columbus, OH: Charles E. Merrill. 
Commission on Social Studies of the American Historical Association (1934).

Conclusions and recommendations. New York: Charles Scribner's Sons.

Counts, G. S. (1932). Dare the school build a new social order? New York: The John Day Company.

Crocco, M., \& Thornton, S. J. (2002). Social studies in the New York City public schools: A descriptive study. Journal of Curriculum and Supervision, 17, 206231.

Cuban, L. (1993). How teachers taught: Constancy and change in American classrooms, 1800-1900 ( $2^{\text {nd }}$ ed.). New York: Teachers College Press.

Davies, P., Davies, R., \& Lynch, D. (2003). Enlivening secondary history: 40 classroom activities for teachers and pupils. New York: Routledgefalmer.

Dickinson, A. K., \& Lee, P. J. (1978). History teaching and historical understanding.

Portsmouth: Heinemann Educational.

Dunn, R. (1999). Contending definitions of world history: Introduction. Issues in Global Education. 151. Retrieved January 1, 2009 at http://www.globaled.org/issues/151/index.html.

Ellington, L. \& Eaton, J.S. (2003). Multiculturalism and social studies. In J. Leming, L. Ellington, \& K. Porter-Magee (Eds.), Where did social studies go wrong? (Chapter 4). Washington D.C.: Thomas B. Fordham Foundation.

Ehman, L., Mehlinger, H., \& Patrick, J. (1974). Toward effective instruction in secondary social studies. Boston: Houghton Mifflin.

Engle, S.H. (1960). Decision making. In W.C. Parker (Ed.), Educating the democratic mind (pp. 117-126). New York: State of New York Press. 
(1971). Exploring the meaning of the social studies. Social Education, 35, 280-288.

Engle, S. H., \& Ochoa, A. S. (1988). Education for democratic citizenship: Decision making in the social studies. New York: Teachers College Press.

Entman, R. M. (2004). Projections of power: Framing news, public opinion, and U.S. foreign policy. Chicago, IL: The University of Chicago Press.

Etmer, P. A. (2005). Teacher pedagogical beliefs: The final frontier in our quest for technology integration? Educational Technology Research and Development. 4, 25-39.

Esposito, A. (2003). The representation of woman in fifth grade and eighth grade recently published U.S. history textbooks. Unpublished master's thesis, San Francisco State University.

Evans, R. W. (2004). The social studies wars: what should we teach the children?. New York: Teachers College Press. (2007). This happened in America: Harold Rugg and the censure of social studies. Charlotte, NC: Information Age Publishing.

Fenton, E. (1991). Reflections on the "New Social Studies.” Social Studies, 82, 84-90.

Fischer, D. H. (1970). Historians' fallacies: Toward a logic of historical thought. New York: Harper \& Row.

Fiske, J. (1894). A History of the United States. New York: Century.

Fleming, J. (1983). Black women in black and white college environments: The making of a matriarch. Journal of Social Issues, 39(3), 41-54.

Florida Commission on Social Studies Education. Connections, challenges, and choices. 
Tallahassee: Florida Department of Education.

Foster, S. J. (1999). The struggle for American identity: Treatment of minority groups in United States history textbooks. History of Education. 28, 251-78.

Foster, S., \& Nicholls, J. (2005). American in World War II: An analysis of history textbooks from England, Japan, Sweden, and the United States. Journal of Curriculum and Supervision. 20, 214-233.

Fredericks, A. D., Meinbach, A. M., \& Rothlein, L. (1993). Thematic units: An integrated approach to teaching science and social studies. New York: Harper Collins.

Garcia, J. (1986). A comparative investigation: The white ethnic experience in selected U.S. history textbooks. The Social Studies, 77, 169-175.

Garcia, J., \& Tanner, D.E. (1985). The portrayal of black Americans in U.S. history textbooks. The Social Studies, 76, 200-204.

Gerwin, D., \& Viscone, F. (2006). The freedom to teach: Contrasting history teaching in elective and state-tested courses. Theory and Research in Social Education, 34, 259282.

Gossett, T. F. (1997). The history of an idea in America. New York: Oxford University.

Grant, S. G. (2004). History lessons: Teaching, learning, and testing in U.S. high school classrooms. Mahwah, NJ: Erlbaum.

Greene, S. (1994). Students as authors in the study of history. In G. Leinhardt, I. L. Beck, \& C. Stainton (Eds.), Teaching and learning in history (pp.137-171). Hillsdale, NJ: Lawrence Erlbaum.

Gross, R.E., Dynneson, T.L. (1983). What should we be teaching in the social studies? Bloomington: Pi Delta Kappa Educational Foundation. 
Hahn, C. L. (1999). Citizenship education: An empirical study of policy, practices and outcomes. Oxford Review of Education, 25, 231-250.

Hahn, C. L., Bernard-Powers, J., Smith Crocco, M., \& Woyshner, C. (2007). Gender equity in social studies. In S.S. Klein (Ed.), Handbook for achieving gender equity through education (pp. 335-357). New Jersey: Lawrence Erlbaum.

Hahn, C.L. \& Blankenship, G. (1983). Women and economic textbooks. Theory and Research in Social Education, 11(3), 67-76.

Haller, J. S, Jr. (1971). Outcasts from evolution: Scientific attitudes of racial inferiority, 1859-1900. Urbana: University of Illinois Press.

Hartoonian, M. (2002). Economics and ethics. Social Education. 66, 311-314.

Henretta, J. A., Brody, D. \& Dumenil, L. (2006). America: a concise history, $3^{\text {rd }}$ ed. Bedford: St. Martins.

Her Majesty's Inspectorate. (1989). The teaching and learning of history and geography. London: Department of Education and Sciences.

Hertzberg, H. W. (1981). Social studies reform 1880-1980. Boulder, CO: SSEC Publications.

Hess, D. (2008). Controversial issues and democratic discourse. In L. S. Levstik \& C. A. Tyson (Eds.), Handbook of research in social studies education (pp. 124-136). New York: Routledge.

Hicks, D., \& Doolittle, P. (2008). Fostering analysis in historical inquiry through multimedia embedded scaffolding. Theory and Research in Social Education. $36,206-232$.

Holsti, O. R. (1969). Content analysis for the social sciences and humanities. Reading, 
MA: Addison-Wesley.

Horsman, R. (1981). Race and manifest destiny: The origins of American racial AngloSaxonism. Cambridge: Harvard University Press.

Houghton Mifflin Harcourt. Retrieved June 1, 2009 from http://www.hmhco.com/leadership.html.

Huitt, W. (2001). Humanism and open education. Educational Psychology Interactive. Valdosta, GA: Valdosta State University. Retrieved December 20, 2007 from http://chiron.valdosta.edu/whuitt/col/affsys/humed.html.

Jenness, D. (1990). Making sense of social studies. New York: Macmillan Publishing Company.

Katz, M. B. (1968). The irony of early school reform. Cambridge, MA: Harvard University Press.

Kinder, D., Bursuck, B., \& Epstein, M. (1992). An evaluation of history textbooks. Journal of Special Education. 25, 472-491.

Kliebard, H. M. (1995). The struggle for the American curriculum: 1893-1958 (2 ${ }^{\text {nd }}$ ed.). New York: Routledge.

Kniep, W. M. (1989). Social studies within a global education. Social Education, 53, 399-403.

Kohl, H. (1969). The open classroom. New York: Vintage.

Lavere, D. B. (2005). Native Americans in U.S. history textbooks: An analysis. Unpublished doctoral dissertation, Clemson University.

Leinhardt, G. (1994). History: A time to be mindful. In G. Leinhardt, I. L. Beck, \& C. Stainton (Eds.), Teaching and learning in history (pp.209-255). Hillsdale, NJ: 
Lawrence Erlbaum.

Levstik, L. S. (1993). Building a sense of history in a first-grade classroom. In J. Brophy (Ed.), Advances in research on teaching: Vol. 4. Case studies of teaching and learning in social studies (pp. 1-31). Greenwich, CT: JAI Press. (2008). What happened in social studies classrooms? Research on K-12 social studies practice. In L. A. Levstik and C. A. Tyson (Eds.), Handbook of research on social studies education (pp. 50-62). New York: Routledge.

Levstik, L. S., \& Barton, K. C. (2004). Teaching history for the common good. New Jersey: Lawrence Erlbaum Associates.

Levstik, L.S. \& Barton, K.C. (2001). Committing acts of history: mediated action, humanistic education, and participatory democracy. In W.B. Stanely (Ed.), Critical issues in social studies research for the $21^{\text {st }}$ century (pp. 119-148). Connecticut: Information Age Publishing. (2005). Doing history: Investigating with children in elementary and middle schools. New York: Routledge.

Lewin, T. (2009, August 8). In a digital future, textbooks are history [Electronic version]. The New York Times, pp. A1.

Library of Congress (2002). Evaluating Primary Sources. Retrieved June 22, 2008 from http://lcweb2.loc.gov/learn/educators/workshop/primary/start.html. Mahoney, K. O. (1988). Geography and Education. Seattle: Educare Press. Mansbridge, J. J. (1990). Self-interest in the explanation of political life. In J. J. Mansbridge (Ed.), Beyond self-interest (pp. 3-22). Chicago: The University of Chicago Press. 
Marker, G., \& Mehlinger, H. (1992). Social Studies. In P. W. Jackson (Ed.), Handbook of research on curriculum (pp. 830-851). New York: Macmillan.

Marshall, L. C. and Goetz, R. M. (1936). Curriculum-making in the social studies. New York: Charles Scribner's Sons.

McCabe, P. P. (1993). The considerateness of fifth grade social studies texts. Theory and Research in Social Education. 21, 128-142.

Merryfield, M. M. (2008). Scaffolding social studies for global awareness. Social Education. 72, 363-366.

Metcalf, S. (2002). Reading between the lines. The Nation. January 28, 2002.

Milken Institute (2009). Milken Institute Global Conference 2009. Retrieved June 1, 2009 from http://www.milkeninstitute.org/events/gcprogram.taf?function $=$ bio\&EventID=GC09\&SPID=4148.

Moreau, J. (2003). Schoolbook nation: conflicts over American history textbooks from the Civil War to the present. Ann Arbor, MI: The University of Michigan Press.

Musbach, J. W. (2001). Using primary sources in the secondary classroom [Electronic version]. OAH Magazine of History, 12.

Muzzey, D. S. (1911). An American History. Boston: Ginn and Co.

Nash, G. B. (2002). American Odyssey: The United States in the $20^{\text {th }}$ Century. Ohio: McGraw-Hill/Glencoe.

Nash, G. B., Crabtree, C., \& Dunn, R. E. (1997). History on trial: Culture wars and the teaching of the past. New York: A.A. Knopf.

National Archives and Records Administration (2008). Teaching with documents: Lesson plans. Retrieved July 28, 2008 from http://www.archives.gov/education/lessons/. 
National Assessment of Educational Progress (2002). 2001 Geography Assessment. Retrieved July 25, 2008 from http://necs.ed.gov/nationsreportcard/geography/. (2007). 2006 Civics Assessment. Retrieved

July 25, 2008 from http://necs.ed.gov/pubsearch/pubsinfo.asp?pubid=2007476. (2007). 2006 U.S. History. Retrieved July

25, 2008 from http://necs.ed.gov/nationsreportcard/ushistory/.

National Council for the Social Studies (1988). Social studies for early childhood and elementary school children preparing for the $21^{\text {st }}$ century: A report from the NCSS Task Force on early childhood/elementary social studies. Washington, DC: National Council for the Social Studies. (2008). Expectations of excellence: content standards for social studies. Retrieved January 1, 2009 from http://www.socialstudies.org/system/files/StandardsDraft10_08.pdf.

National Curriculum Council. (1991). History in the national curriculum (statutory orders and non-statutory guidelines). London: Department of Education and Science.

National Education Association (1893). Report of the Committee on Secondary Social Studies. Washington DC: U.S. Government Printing Office. (1918). Cardinal principles of secondary education: A report of the Commission on the reorganization of secondary education. Washington, D.C.: U.S. Government Printing Office.

Newmann, F., \& Wehlage, G. (1995). Successful school restructuring. Madison: Center on Organization and Restructuring of Schools, University of Wisconsin-Madison. 
Nicholls, J. (2003). Methods in school textbook research. International Journal of Historical Learning, Teaching, and Research. 3, 1-6.

Ochoa-Becker, A. S. (2007). Democratic education for social studies: An issues-centered decision making curriculum ( $2^{\text {nd }}$ ed.). Greenwich, CT: Information Age Publishing.

Parker, W. C. (2002). Education for democracy: Contexts, curricula, assessments, research in social education. Greenwich: Information Age Publishing. (2003). Teaching democracy: Unity and diversity in public life. New York: Teacher's College Press.

Passe, J. (2006). New challenges in elementary social studies. Social Studies, 97, 189192.

Patrick, J. J. \& Hawke, S. (1982). Social studies curriculum materials. In The current state of social studies: A report of Project Span (pp. 105-185). Boulder, CO: Social Science Education Consortium.

Patrick, J. J., Vontz, T. S., \& Nixon, W.C. (2002). Issue-centered education for democracy through Project Citizen. In W.A. Parker (Eds.), Education for democracy (pp. 93-112). Greenwich: Information Age Publishing.

Paxton, R. J. (1999). A deafening silence: History textbooks and the students who read them. Review of Educational Research. 69, 315-339.

Pearson (2009). About us. Retrieved June 1, 2009 from http://www.pearson.com/index.cfm? pageid $=16$.

Peet, T. S. (1984). A selective history of social studies scope and sequence patterns, 1916 to 1984. Unpublished dissertation, The Ohio State University. 
Pinar, W. F., Reynolds, W. M., Slattery, P., \& Taubman, P. M. (1995). Understanding curriculum. An introduction to the study of historical and contemporary curriculum discourses. Counterpoints: Studies in the postmodern theory of education, Vol. 17. New York: Peter Lang.

Pingel, F. (1999). UNESCO guidebook on textbook research and textbook revision. Hannover: Verlag Hahnsche Buchhandlung.

Ravitch, D. (1990). Multiculturalism: E pluribus plures. The American Scholar, 59(3), $337-54$. (2001). Left back: A century of failed school reforms. New York: Simon and Schuster. (2003). The language police: How pressure groups restrict what students learn. New York: Knopf.

Ravich, D., \& Finn, C. E. (1987). What do our 17-year-olds know? New York: Harper \& Row.

Richter, D. (1993). Whose Indian history? William and Mary Quarterly. 53, 435-58.

Riverdeep. Executive Bios. Retrieved June 1, 2009 from http://web.riverdeep.net/portal/page?_pageid=813,1374328\&_dad=portal\&_schema =PORTAL,

Robinson, P. \& Kirman, J.M. (1986). From monopoly to dominance. In S.P. Wronski \& D.H. Bragaw (Eds.), Social studies and social sciences: A fifty-year perspective (pp. 15-27). Washington D.C.: NCSS. 
Rock, T. C., Heafner, T., O’Connor, K., Passe, J., Oldendorf, S., Good, A., \& Byrd, S. (2004). One state closer to a national crisis: A report on elementary social studies education in North Carolina schools. Theory and Research in Social Education, $34,455-483$.

Romanish, B.A. (1983). Modern secondary economics textbooks and ideological bias. Theory and Research in Social Education, 11(1), 1-24.

Rosen, Judith. (2009). Gentel named president of Houghton Mifflin Harcourt. Publisher's Weekly. Retrieved June 1, 2009 from http://www.publishersweekly.com/article/CA6513591.html.

Rouet, J., Favart, M., Britt, M. A., \& Perfetti, C. A. (1997). Studying and using multiple documents in history: effects on discipline expertise. Cognition and Instruction. $15,85-106$.

Rugg, H. O. (1921). Needed changes in the committee procedure of reconstructing the social studies. The Elementary School Journal, 21, 688-702.

(1923). Do the social studies prepare pupils adequately for life activities? In G. M. Whipple (Ed.), The twenty-second The twenty-second yearbook of the National Society for the Study of Education, Part II: The social studies in the elementary and secondary school (pp. 1-27). Bloomington, Ill: Public School Publishing.

Sanchez, A. (1999). The depiction of Native Americans in recent (1991-1998) secondary American history textbooks. West Lafayette, IN: Purdue University Press. 
Satyendra, N. (2003). What is a Nation?: Definition of a Nation. Retrieved November 27, 2008 from http://www.tamilnation.org/nation.htm.

Saye, J. W., \& Brush, T. A. (1999). Student engagement with social issues in a multimedia-supported learning environment. Theory and Research in Social Education, 27, 472-504.

Schlesinger, A. M., Jr. (1998). The disuniting of America: Reflections on a multicultural society. New York: W.W. Norton.

Selden, S. (1999). Inheriting shame: The story of eugenics and racism in America. New York: Teachers College Press.

Siler, C.L. (1987). Content analysis: A process for textbook analysis and evaluation. International Journal of Social Education, 1(3), 78-97.

Sleeter, C. (1995). An analysis of the critiques of multiculturalism education. In J. A. Banks and C. A. M. Banks (Eds.). The handbook of research on multicultural education (pp. 81-94). New York: Macmillan.

Sleeter, C., \& Grant, C. (1991). Race, class, gender, and disability in current textbooks. In M. W. Apple \& L. K. Christian-Smith (Eds.), The politics of the textbook (pp. 78110). New York: Routledge.

Stanford University History Department. (2009). Department overview. Retrieved July 5, 2009 from http://www.stanford.edu/dept/history/home/index.html.

Stradling, R. (2001). Teaching 20th - century European history. Strasbourg: Council of Europe Publishing.

Symcox, L. (2002). Whose history? The struggle for national standards in American classrooms. New York: Teacher's College Press. 
Takaki, R.T. (1979). Iron cages: Race and culture in nineteenth-century America. New York: Random House.

Tetreault, M. K. (1984). Notable American women: The case of U.S. history textbooks. Social Education. 48, 546-550.

Thurbayne, C. M. (1962). The myth of the metaphor. New Haven: Yale University Press.

Tryon, R. M. (1935). The social sciences as school subjects. In the American Historical Association Report of the Commission on the Social Studies (Part 11). New York: Scribner's.

Tyson, H., \& Woodward, A. (1989). Why students aren't learning very much from textbooks. Educational Leadership, 49, 14-17.

University of Princeton History Department. (2009). Department overview. Retrieved July 5, 2009 from http://www.princeton.edu/history/info/.

U.S. Department of Education's National Commission on Excellence in Education (1983). A nation at risk: the imperative for educational reform. Washington, D.C.: National Press.

VanFossen, P. J. (2000). An analysis of the use of the internet and world wide web by secondary social studies teachers in Indiana. International Journal of Social Education, 14, 87-109.

VanFossen, P. J., \& Waterson, R. (2008). It's just easier to do what you did before...:An update on internet use in secondary social studies classrooms in Indiana. Theory and Research in Social Education, 36, 124-152.

Von Zastrow, C., \& Janc, H. (2004). The condition of the liberal arts in America's public schools. New York: Teachers College Press. 
Wade, R. C. (1993). Content analysis of social studies textbooks: A review of ten years of research. Theory and Research in the Social Education, 21, 232-256.

Wallace, S. L., \& Allen, M. D. (2008). Survey of African American portrayal in introductory textbooks in American government/politics: A report of the APSA Standing Committee on the status of Blacks in the profession [Electronic version]. PS: Political Science \& Politics, 41, 153-160.

Walz, J. A. (1936). German Influence in American Education and Culture. Philadelphia: Carl Schruz Memorial Foundation, Inc.

Watras, J. (2002). Debating the curriculum: Social studies or history, 1892-1937. The Social Studies, 93, 245-250.

Webb, N. L. (2005). "Web Alignment Tool” 24 July 2005. Wisconsin Center of Educational Research. University of Wisconsin-Madison. Retrieved November 20, 2008, from http://www.wcer.wisc.edu/WAT/index.aspx.

Weinbrenner, P. (1992). Methodologies of textbook analysis used to date. In H. Bourdillon (Ed.). History and Social Studies - Methodologies of Textbook Analysis (pp. 21-34). Amsterdam: Swets and Zeitlinger.

Wineburg, S. S. (1991). On the reading of historical texts: Notes on the breach between school and the academy. American Educational Research Journal, 28, 495-519.

Wineburg, S. (2001) Historical thinking and other unnatural acts. Philadelphia: Temple University Press.

Woodward, A. (1987). Textbooks: Less than meets the eye. Journal of Curriculum Studies, 19, 511-526.

Wronski, S. P., \& Bragaw, D. H. (1986). Social studies and social sciences: A fifty-year 
perspective (Bulletin No. 78). Washington, D.C.: National Council for the Social Studies.

Young, K. M., \& Leinhardt, G. (1998). Writing from primary documents: A way of knowing in history. Written Communication, 15, 25.

Zimmerman, B.J. (2002). Becoming a self-regulated learner: An overview. Theory Into Practice, 41(2), 64-70. 


\section{Appendix A: Instrument Review}

Please classify the types of primary sources on the following criteria.

\begin{tabular}{|c|c|c|c|}
\hline \multirow{2}{*}{$\begin{array}{c}\text { Primary Source } \\
\text { Name }\end{array}$} & \multirow{2}{*}{$\begin{array}{l}\text { Type of primary source: } \\
\text { Artifact } \\
\text { Original Photograph } \\
\text { Excerpt from Original } \\
\text { Document } \\
\text { Political Cartoon } \\
\text { Artwork } \\
\text { Other (please specify) }\end{array}$} & \multicolumn{2}{|c|}{ Corresponding question analysis } \\
\hline & & $\begin{array}{l}\text { LOC level of analysis } \\
\text { Scan } \\
\text { Examine } \\
\text { Analyze } \\
\text { Compare }\end{array}$ & $\begin{array}{ll} & \text { DOK level } \\
1 & \\
2 & \\
3 & \\
4 & \end{array}$ \\
\hline Join or Die & & & \\
\hline Leonardo da vinci & & & \\
\hline Bacon's Rebellion & & & \\
\hline Sermon & & & \\
\hline Common Sense & & & \\
\hline $\begin{array}{l}\text { Constitutional } \\
\text { Political Cartoon }\end{array}$ & & & \\
\hline Farwell Address & & & \\
\hline Menlo Park Lab & & & \\
\hline McGuffey Reader & & & \\
\hline Battle of Lexington & & & \\
\hline Great Gatsby & & & \\
\hline $\begin{array}{l}\text { Immigration Political } \\
\text { Cartoon }\end{array}$ & & & \\
\hline McCain Biography & & & \\
\hline Reagan Speech & & & \\
\hline $\begin{array}{l}\text { WWII Propaganda } \\
\text { Poster }\end{array}$ & & & \\
\hline
\end{tabular}


Appendix B: Textbook's Treatment of Primary Sources Evaluation Instrument

Textbook Title:

Author:

Publisher:

Date Published:

Intended Grade Level(s):

Category 1: General information

\begin{tabular}{|l|l|l|l|l|l|l|l|}
\hline & Frequency & $\begin{array}{l}\text { Directly } \\
\text { Under }\end{array}$ & None & $\begin{array}{l}\text { Prior or } \\
\text { following } \\
\text { page }\end{array}$ & $\begin{array}{l}\text { Elsewhere } \\
\text { on same } \\
\text { page }\end{array}$ & $\begin{array}{l}\text { End of } \\
\text { Chapter }\end{array}$ & $\begin{array}{l}\text { End } \\
\text { of } \\
\text { Book }\end{array}$ \\
\hline $\begin{array}{l}\text { Written } \\
\text { Document }\end{array}$ & & & & & & & \\
\hline $\begin{array}{l}\text { Contemp. } \\
\text { Photo of } \\
\text { ancient site }\end{array}$ & & & & & & & \\
\hline Artwork & & & & & & & \\
\hline $\begin{array}{l}\text { Political } \\
\text { cartoon }\end{array}$ & & & & & & & \\
\hline Photograph & & & & & & & \\
\hline $\begin{array}{l}\text { Images of } \\
\text { Artifacts }\end{array}$ & & & & & & & \\
\hline $\begin{array}{l}\text { Historical } \\
\text { maps }\end{array}$ & & & & & & & \\
\hline
\end{tabular}




\section{Category 2: Textbook's Primary Source Content}

1. How often do the questions corresponding to the textbook's primary sources ask the students to utilize the various elements of the Library of Congress's guidelines for primary source analysis? How often are the primary sources presented only as page page filler? Are the answers to the questions posed found in the text?

*A description of each category can be found at the end of this instrument.

\begin{tabular}{|c|c|c|c|c|c|c|c|c|c|c|c|c|c|c|}
\hline LOC & \multicolumn{2}{|c|}{$\begin{array}{l}\text { Written } \\
\text { Documents }\end{array}$} & \multicolumn{2}{|c|}{$\begin{array}{l}\text { Contemp. } \\
\text { Photo of } \\
\text { ancient site }\end{array}$} & \multicolumn{2}{|c|}{ Artwork } & \multicolumn{2}{|c|}{$\begin{array}{l}\text { Political } \\
\text { Cartoon }\end{array}$} & \multicolumn{2}{|c|}{ Photographs } & \multicolumn{2}{|c|}{$\begin{array}{l}\text { Images of } \\
\text { Artifacts }\end{array}$} & \multicolumn{2}{|c|}{$\begin{array}{l}\text { Historical } \\
\text { Maps }\end{array}$} \\
\hline \multicolumn{15}{|l|}{ Scan } \\
\hline \multicolumn{15}{|l|}{ Examine } \\
\hline \multicolumn{15}{|l|}{ Analyze } \\
\hline \multicolumn{15}{|l|}{ Compare } \\
\hline \multicolumn{15}{|l|}{ Page Filler } \\
\hline Answer in & Yes & No & Yes & No & Yes & No & Yes & No & Yes & No & Yes & No & Yes & No \\
\hline
\end{tabular}


2. How often do the questions corresponding to the textbook's primary sources fall under one of the categories of the DOK? How often are the primary sources presented only as page page filler? Are the answers to the posed questions found in the text?

\begin{tabular}{|c|c|c|c|c|c|c|c|c|c|c|c|c|c|c|}
\hline DOK & \multicolumn{2}{|c|}{$\begin{array}{l}\text { Written } \\
\text { Documents }\end{array}$} & \multicolumn{2}{|c|}{$\begin{array}{l}\text { Contemp. } \\
\text { Photo of } \\
\text { ancient site }\end{array}$} & \multicolumn{2}{|c|}{ Artwork } & \multicolumn{2}{|c|}{$\begin{array}{l}\text { Political } \\
\text { Cartoon }\end{array}$} & \multicolumn{2}{|c|}{ Photographs } & \multicolumn{2}{|c|}{$\begin{array}{l}\text { Images of } \\
\text { Artifacts }\end{array}$} & \multicolumn{2}{|c|}{$\begin{array}{l}\text { Historical } \\
\text { Maps }\end{array}$} \\
\hline \multicolumn{15}{|l|}{1} \\
\hline \multicolumn{15}{|l|}{2} \\
\hline \multicolumn{15}{|l|}{3} \\
\hline \multicolumn{15}{|l|}{4} \\
\hline \multicolumn{15}{|l|}{ Page Filler } \\
\hline \multirow{2}{*}{$\begin{array}{l}\text { Answer in } \\
\text { text? }\end{array}$} & Yes & No & Yes & No & Yes & No & Yes & No & Yes & No & Yes & No & Yes & No \\
\hline & & & & & & & & & & & & & & \\
\hline
\end{tabular}


3. Examine the primary documents and indicate the frequency with which specific ethnic groups, gender classifications, and religious groups are represented. What key adjectives used in the corresponding questions might indicate the potential book bias? Using the Depth of Knowledge (DOK) Level chart, indicate the average level of the corresponding questions.

\begin{tabular}{|c|c|c|c|c|c|c|c|c|c|c|c|}
\hline \multirow{3}{*}{$\begin{array}{l}\text { Ethnic } \\
\text { Group }\end{array}$} & \multirow{3}{*}{ Frequency } & \multirow{3}{*}{$\begin{array}{l}\text { No question } \\
\text { asked }\end{array}$} & \multirow{3}{*}{ Adjective(s) } & & & & & \multicolumn{4}{|c|}{ Amount of Page Devoted } \\
\hline & & & & \multicolumn{4}{|c|}{ Depth of Question Level } & \multirow[t]{2}{*}{$<1 / 4$ page } & \multirow{2}{*}{$\begin{array}{l}\text { 1/4-1/2 } \\
\text { page }\end{array}$} & \multirow{2}{*}{$\begin{array}{l}1 / 2-3 / 4 \\
\text { page }\end{array}$} & \multirow{2}{*}{\begin{tabular}{|l|}
$>3 / 4$ \\
page
\end{tabular}} \\
\hline & & & & 1 & 2 & & 4 & & & & \\
\hline & & & & & & & & & & & \\
\hline & & & & & & & & & & & \\
\hline & & & & & & & & & & & \\
\hline & & & & & & & & & & & \\
\hline & & & & & & & & & & & \\
\hline & & & & & & & & & & & \\
\hline & & & & & & & & & & & \\
\hline & & & & & & & & & & & \\
\hline & & & & & & & & & & & \\
\hline & & & & & & & & & & & \\
\hline & & & & & & & & & & & \\
\hline
\end{tabular}




\begin{tabular}{|c|c|c|c|c|c|c|c|c|c|c|c|}
\hline \multirow{3}{*}{$\begin{array}{l}\text { Gender } \\
\text { Classification }\end{array}$} & \multirow{3}{*}{ Frequency } & \multirow{3}{*}{$\begin{array}{l}\text { No question } \\
\text { asked }\end{array}$} & \multirow{3}{*}{ Adjective(s) } & & & & & \multicolumn{4}{|c|}{ Amount of Page Devoted } \\
\hline & & & & \multicolumn{4}{|c|}{ Depth of Question Level } & \multirow{2}{*}{$<1 / 4$ page } & \multirow{2}{*}{$\begin{array}{l}\text { page } \\
\text { page }\end{array}$} & \multirow{2}{*}{$\begin{array}{l}\text { 1/2-3/4 } \\
\text { page }\end{array}$} & \multirow{2}{*}{$\begin{array}{l}>3 / 4 \\
\text { page }\end{array}$} \\
\hline & & & & 1 & 2 & 3 & 4 & & & & \\
\hline & & & & & & & & & & & \\
\hline & & & & & & & & & & & \\
\hline & & & & & & & & & & & \\
\hline
\end{tabular}

\begin{tabular}{|c|c|c|c|c|c|c|c|c|c|c|c|}
\hline \multirow{3}{*}{\begin{tabular}{|l|} 
Religious \\
Group
\end{tabular}} & \multirow{3}{*}{ Frequency } & \multirow{3}{*}{$\begin{array}{l}\text { No question } \\
\text { asked }\end{array}$} & \multirow{3}{*}{ Adjective(s) } & & & & & \multicolumn{4}{|c|}{ Amount of Page Devoted } \\
\hline & & & & \multicolumn{4}{|c|}{ Depth of Question Level } & \multirow[t]{2}{*}{$<1 / 4$ page } & \multirow{2}{*}{$\begin{array}{l}\text { 1/4-1/2 } \\
\text { page }\end{array}$} & \multirow{2}{*}{$\begin{array}{l}\text { 1/2-3/4 } \\
\text { page }\end{array}$} & \multirow{2}{*}{$\begin{array}{l}>3 / 4 \\
\text { page }\end{array}$} \\
\hline & & & & 1 & 2 & 3 & 4 & & & & \\
\hline & & & & & & & & & & & \\
\hline & & & & & & & & & & & \\
\hline & & & & & & & & & & & \\
\hline & & & & & & & & & & & \\
\hline
\end{tabular}


4. Examine the primary sources and indicate which specific historical figures are represented and the frequency with which he/she is represented? What key adjectives used in the corresponding questions might indicate the potential book bias? Using the Depth of Knowledge (DOK) Level chart, indicate the average level of the corresponding questions.

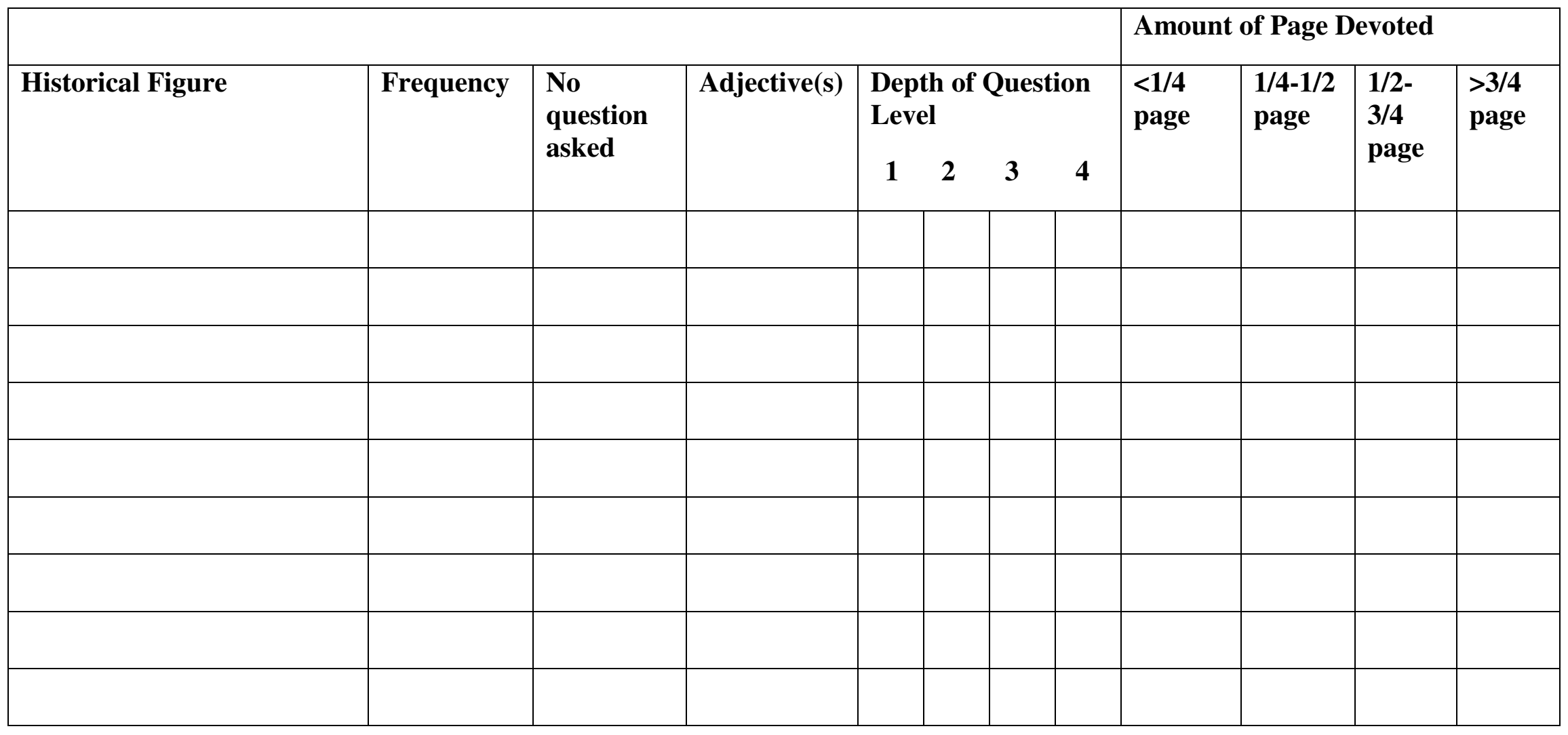


5. Examine the primary sources and indicate which specific political groups are represented and the frequency with which it is represented? What key adjectives used in the corresponding questions might indicate the potential book bias? Using the Depth of Knowledge (DOK) Level chart, indicate the average level of the corresponding questions.

\begin{tabular}{|c|c|c|c|c|c|c|c|c|c|c|}
\hline \multirow{3}{*}{ 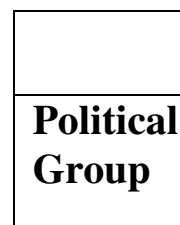 } & \multirow{3}{*}{ Frequency } & \multirow{3}{*}{$\begin{array}{l}\text { No question } \\
\text { asked }\end{array}$} & \multirow{3}{*}{ Adjective(s) } & & & & \multicolumn{4}{|c|}{ Amount of Page Devoted } \\
\hline & & & & \multicolumn{3}{|c|}{ Depth of Question Level } & \multirow[t]{2}{*}{$<1 / 4$ page } & \multirow{2}{*}{$\begin{array}{l}\text { 1/4-1/2 } \\
\text { page }\end{array}$} & \multirow{2}{*}{$\begin{array}{l}\text { page } \\
\text { page }\end{array}$} & \multirow{2}{*}{$\begin{array}{l}>3 / 4 \\
\text { page }\end{array}$} \\
\hline & & & & & 2 & 3 & & & & \\
\hline & & & & & & & & & & \\
\hline & & & & & & & & & & \\
\hline & & & & & & & & & & \\
\hline & & & & & & & & & & \\
\hline & & & & & & & & & & \\
\hline & & & & & & & & & & \\
\hline & & & & & & & & & & \\
\hline & & & & & & & & & & \\
\hline
\end{tabular}




\section{Category 3: Pedagogical Approach}

1. According to the preface, what do the authors claim as the purpose of the textbook?

2. According to the preface, what do the authors claim is the purpose of the primary sources? 
Category 4: Intrinsic Qualities of the Textbook

1. Who are the stakeholders?

2. What are the potential biases of the stakeholders? 


\section{Category 5: Extrinsic Factors Influencing the Textbook}

1. When was the book first introduced to the market? What is the current edition? When was it introduced?

2. What is the price of the current edition?

3. Is the book aimed at a specific group? If so, who?

4. To what extent is the alternative resources intended to complement the textbook?

5. What alternative resources are provided? 


\section{Library of Congress's Guidelines for Primary Source Analysis}

i. Scan - the source, performing a physical examination: its condition, any artwork, any extraneous markings or other clues to the source's context or history EG: Examine the picture below. Scroll from left to right. Using the photo analysis guide, describe what you see.

ii. Examine - for information about the subject, audience, setting, and purpose of this source. EG: Who was the map made for? For what purpose?

iii. Analyze - the source, attempting to integrate factual observations, prior knowledge, and intuition to reconstruct the story behind the source. EG: How accurate do you consider the map for its use?

iv. Compare - the image with others. Use all the information you have learned from each primary source to place them in context with each other. EG: How does it compare to the picture on page 55 ? 


\section{Depth of Knowledge}

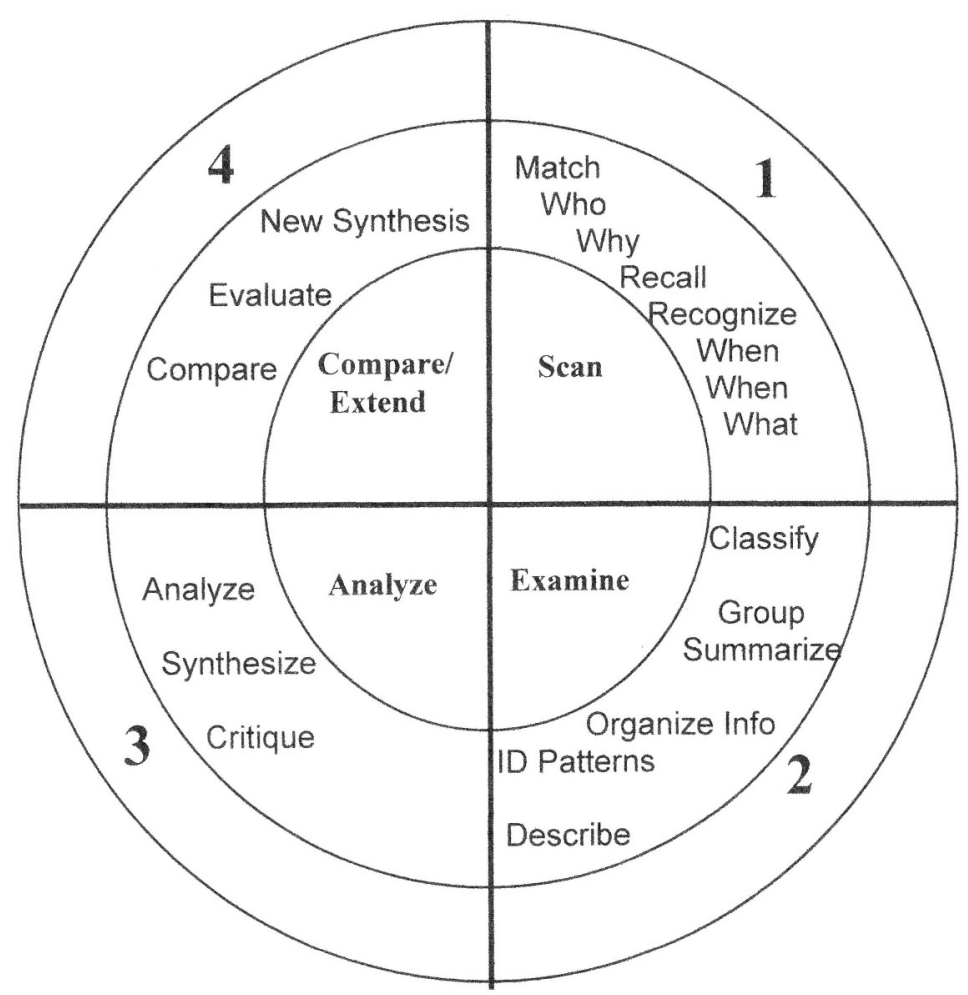

\begin{tabular}{|l|l|l|l|}
\hline \multicolumn{1}{|c|}{$\begin{array}{c}\text { Level One } \\
\text { Questions }\end{array}$} & \multicolumn{1}{|c|}{$\begin{array}{c}\text { Level Two } \\
\text { Questions }\end{array}$} & $\begin{array}{l}\text { Level Three } \\
\text { Questions }\end{array}$ & $\begin{array}{c}\text { Level Four } \\
\text { Questions }\end{array}$ \\
\hline $\begin{array}{l}\text { List the reasons } \\
\text { religious pacifists } \\
\text { thought it was } \\
\text { wrong to serve in } \\
\text { the military. }\end{array}$ & $\begin{array}{l}\text { Summarize the } \\
\text { message delivered } \\
\text { on The Fourteen } \\
\text { Points speech. }\end{array}$ & $\begin{array}{l}\text { Draw conclusions } \\
\text { as to what impact } \\
\text { The Jungle might } \\
\text { have had on the } \\
\text { meat industry. }\end{array}$ & $\begin{array}{l}\text { Create song lyrics } \\
\text { embodying the } \\
\text { passage's essence. }\end{array}$ \\
\hline $\begin{array}{l}\text { Recall the major } \\
\text { battle sites } \\
\text { identified on the } \\
\text { map }\end{array}$ & $\begin{array}{l}\text { Describe the cause } \\
\text { and effects of the } \\
\text { adoption of the } \\
\text { Emancipation } \\
\text { Proclamation }\end{array}$ & $\begin{array}{l}\text { Determine the } \\
\text { author's purpose } \\
\text { and describe how it } \\
\text { affects your } \\
\text { interpretation of his } \\
\text { work. }\end{array}$ & $\begin{array}{l}\text { Based on the diary, } \\
\text { design a map } \\
\text { detailing the } \\
\text { migration pattern. }\end{array}$ \\
\hline $\begin{array}{l}\text { Who was or might } \\
\text { be the author of the } \\
\text { entry? }\end{array}$ & $\begin{array}{l}\text { Organize the data } \\
\text { found in the journal } \\
\text { entry into } \\
\text { categories }\end{array}$ & $\begin{array}{l}\text { Critique the artist's } \\
\text { interpretation of the } \\
\text { Black Death using } \\
\text { information } \\
\text { provided in the text }\end{array}$ & $\begin{array}{l}\text { Evaluate the } \\
\text { argument } \\
\text { presented by the } \\
\text { pacifists with the } \\
\text { arguments of the } \\
\text { government. }\end{array}$ \\
\hline
\end{tabular}

Chart based on: Webb, N.L. (2005). "Web Alignment Tool" 24 July 2005. Wisconsin Center of Educational Research. University of Wisconsin-Madison. Retrieved on November 20, 2008 from http / www. wcer. wisc.edu/WAT/index.aspx. 